\title{
Petrogenetic study of the Lonco Trapial volcanism and its comparison with the Early-Middle Jurassic magmatic units from northern Patagonia
}

\author{
Claudia Beatriz Zaffarana ${ }^{\mathrm{a}, \mathrm{b}, *}$, Silvia Leonor Lagorio ${ }^{\mathrm{c}}$, Gloria Gallastegui ${ }^{\mathrm{d}}$, Gerhard Wörner ${ }^{\mathrm{e}}$, \\ Darío Leandro Orts ${ }^{\mathrm{a}, \mathrm{b}}$, Daniel Gregori ${ }^{\mathrm{b}, \mathrm{f}}$, Stella Poma ${ }^{\mathrm{b}, \mathrm{g}}$, Alicia Busteros ${ }^{\mathrm{c}}$, Raúl Giacosa ${ }^{\mathrm{c}}$, \\ Diego Silva Nieto ${ }^{c}$, Víctor Ruiz González ${ }^{\mathrm{b}, \mathrm{g}}$, Bárbara Boltshauser ${ }^{\mathrm{a}, \mathrm{b}}$, \\ Carla Puigdomenech Negre ${ }^{\mathrm{b}, \mathrm{g}}$, Miguel Haller ${ }^{\mathrm{b}, \mathrm{h}}$
}

${ }^{a}$ Universidad Nacional de Río Negro. Instituto de Investigación en Paleobiología y Geología, General Roca. Río Negro, Argentina

${ }^{\mathrm{b}}$ CONICET, Consejo Nacional de Investigaciones Científicas y Técnicas, Argentina

${ }^{\mathrm{c}}$ Servicio Geológico y Minero Argentino (SEGEMAR), Argentina

${ }^{\mathrm{d}}$ Instituto Geológico y Minero de España (IGME), Oviedo, Spain

${ }^{\mathrm{e}}$ Georg-August-Universität Göttingen Department of Geochemistry, Germany

${ }^{\mathrm{f}}$ Universidad Nacional del Sur (UNS), Bahía Blanca, Argentina

${ }^{\mathrm{g}}$ Universidad de Buenos Aires (UBA), Buenos Aires, Argentina

${ }^{\mathrm{h}}$ Universidad Nacional de la Patagonia San Juan Bosco, Puerto Madryn, Argentina

\section{A B S T R A C T}

One of the largest silicic igneous provinces of the world, the Chon Aike Volcanic Province, is related to an extensional regime developed in Patagonia in Early to Middle Jurassic times. This work presents new geochemical analyses for major and trace elements from different units in the central domain of northern Patagonia, units known as Lonco Trapial and Garamilla formations. Additionally, some samples were analyzed from the Piltriquitrón and Lago La Plata formations in the western domain of northern Patagonia. One new U-Pb age of a rhyolitic dike (177.26 $\pm 0.96 \mathrm{Ma})$ and new Rb-Sr and Sm-Nd determinations from the Lonco Trapial Formation are also presented in this work. Results presented here fill a gap in geochemical data for the area with respect to the temporal and spatial coverage of the Chon Aike Volcanic Province in northern Patagonia. Our comparative study shows that all Early-Middle Jurassic igneous rocks from this area have mixed characteristics between slab-derived subduction-related settings and intraplate magmas. In the central domain melting must have involved both mantle and lower crust, so that a mixed source is envisaged. Ascent to shallow crustal levels with subsequent low-pressure differentiation followed by assimilation could explain the geochemical features of Lonco Trapial magmas from andesites to subordinated rhyolites. The arc signature of Lonco Trapial magmas located far from the volcanic arc is considered as the result of decompression melting of mantle enriched by previous subduction events rather than by contemporaneous Early Jurassic subduction involving additional contributions of crustal materials. Upper crustal contamination was facilitated by eastwards increasing crustal thicknesses, so Lonco Trapial magmas had to traverse a thicker crust on their way to the surface.

\section{Introduction}

Jurassic-Early Cretaceous times in Patagonia were characterized by widespread extension concomitant with abundant magmatism during the Gondwana break-up stage (e.g. Gust et al., 1985; Uliana and Biddle, 1987; Rapela and Kay, 1988; Pankhurst et al., 2000; Suárez and Márquez, 2007; Mpodozis and Ramos, 2008; Echaurren et al., 2017). The inferred intraplate extension was coeval with the subduction of Pacific oceanic plates in an arc-back-arc basin configuration (Mpodozis and Ramos, 1989). At $41^{\circ}-49^{\circ} \mathrm{S}$, the Early Jurassic paleo-geography was also characterized by the presence of an elongate marine basin east of the present Patagonian Cordillera (Mpodozis and Ramos, 1989). There, black shales and carbonate rocks with abundant ammonite fauna formed during a marine transgression from the Pacific that filled the Chubut Basin (Suárez and Márquez, 2007). This basin has an NNW-SSE orientation and was coeval with the intrusion of the Early Jurassic Subcordilleran Plutonic Belt (Gordon and Ort, 1993; Haller et al., 1999; Rapela et al., 2005), a suite of predominantly felsic and intermediate plutonic rocks.

In Early Jurassic times, the position of the Gondwana subduction zone is marked by andesitic pyroclastic rocks with dacitic intercalations within marine sedimentary units of the Chubut Basin as well as several deeper plutonic bodies of the Subcordilleran Plutonic Belt (e.g., Haller and Lapido, 1982; Echaurren et al., 2017). Later, in the Middle Jurassic, the position of the magmatic arc shifted to the west, indicated by the extrusion of andesites, dacites, and rhyolites of the Ibáñez and Lago La

\footnotetext{
* Corresponding author. Universidad Nacional de Río Negro. Instituto de Investigación en Paleobiología y Geología, General Roca. Río Negro, Argentina.

E-mail address: czaffarana@unrn.edu.ar (C.B. Zaffarana).
} 
Plata formations (Mpodozis and Ramos, 1989; Echaurren et al., 2017). Towards the east, in an intraplate position, central Patagonia was covered by thick volcanic sequences of rhyolitic and andesitic composition that comprise the Marifil Complex and the Lonco Trapial and Garamilla formations. These are equivalent to the "Jurassic Volcanic Province" of Pankhurst and Rapela (1995) and the "Chon Aike Volcanic Province" of Pankhurst et al. (1998). The Chon Aike Volcanic Province has been described as the largest silicic magmatic provinces in the world, which also extends to the Antarctic Peninsula (Pankhurst et al., 1998, 2000; Riley et al., 2001). The early stage of the arc volcanism in the western domain of northern Patagonia developed under syn-extensional conditions (Echaurren et al., 2017) and was synchronous with the waning stage of eruption of the intraplate magmas in the central and eastern domains.

This work revises the tectonic significance of the Early-Middle Jurassic igneous units from northern Patagonia by exploring the geochemical signature of erupted volcanic rocks, the depth of the source and the petrological processes which could have influenced the magmatic evolution in this unusual back-arc setting, where the geochemical signature is intermediate between slab-derived subduction-related settings and intraplate magmas. New whole-rock geochemical data from Lonco Trapial, Garamilla, Piltriquitrón and Lago La Plata formations, as well as geochronological and isotopic data from Lonco Trapial Formation near the Gastre area (Fig. 1) are presented as well. Geochemical comparisons are established between the volcanic suites of central domain of northern Patagonia (Lonco Trapial and Garamilla formations) and their coeval units towards the eastern domain (Marifil Complex) and western domain (the Subcordilleran Plutonic Belt, Piltriquitrón and Lago La Plata formations). The relationship between the two endmembers of the intraplate magmatism (rhyolites and andesites) is further discussed.

\subsection{Early-Middle Jurassic magmatism in north Patagonia}

Mesozoic volcanism in north Patagonia is composed essentially of andesites and rhyolites. Andesites predominate in the central domain of north Patagonia (Fig. 1) where they constitute a belt of Early-Middle Jurassic volcanic rocks which are known as the Lonco Trapial Formation (Page and Page, 1993; c. 185-182 $\mathrm{Ma},{ }^{40} \mathrm{Ar}-{ }^{39} \mathrm{Ar}$ in amphibole, Zaffarana and Somoza, 2012; 189-178 Ma, U-Pb in zircon, Cúneo et al., 2013; c. $191-178 \mathrm{Ma},{ }^{40} \mathrm{Ar}-{ }^{39} \mathrm{Ar}$ in amphibole and whole-rock K-Ar, Zaffarana et al., 2018), whose type locality is near Paso del Sapo (Fig. 1). However, towards the northern part of the central domain, rhyolites tend to be more abundant than andesites, where the rhyolites were mapped as Garamilla Formation and the andesites as Lonco Trapial Formation (Nullo, 1978; González et al., 1999, Fig. 1). All in all, the Early-Middle Jurassic volcanic deposits of the central domain of northern Patagonia are known as Lonco Trapial Formation in the Gastre-Paso del Sapo area and as Garamilla Formation in the northern Ingeniero Jacobacci area (Fig. 1). This correlation is based in the U-Pb zircon age of c. $188 \mathrm{Ma}$ for a rhyolitic tuff reported from the Garamilla Formation by Franzese et al. (2002) in the area comprised within Gastre and Ingeniero Jacobacci.

In the area between Paso del Sapo and Paso de Indios, andesitic volcanic rocks were described by many authors (e.g. Petersen, 1946; Lesta and Ferello, 1972; Nullo and Proserpio, 1975; Volkheimer and Lage, 1981; Turner, 1983; Lizuaín and Silva Nieto, 2005; Silva Nieto et al., 2002; Silva Nieto, 2004). The Lonco Trapial andesites hosting epithermal mineralization in the area of Mina Angela deposit (Dejonghe et al., 2002) where Pankhurst and Rapela (1995) included in this study. The Middle Jurassic Alvar Andesites (K-Ar plagioclase age of 161.4 \pm 7.3 Ma, Aragón et al., 2000) described in the area of Paso del Sapo (Fig. 1) are not included in this study because they are considered as a different unit from Lonco Trapial Formation. In the area of the Navidad epithermal district (Bouhier et al., 2017), an ${ }^{40} \mathrm{Ar}-{ }^{39} \mathrm{Ar}$ plateau age in sanidine of $182.8 \pm 0.8 \mathrm{Ma}$ is reported by Márquez et al. (2016) for the rhyolitic ignimbrites ascribed to the Garamilla Formation. Also, in the Navidad area, andesites belonging to the early units of the Cañadón Asfalto Formation contain zircon crystals of $173 \pm 1.9 \mathrm{Ma}$ and $170.8 \pm 3$ Ma (LA-ICPMS U-Pb ages of Bouhier et al., 2017). As this volcanism is related to the opening of the Cañadón Asfalto Basin, it does not directly correlate with the Lonco Trapial Formation, so these analyses were not included in the geochemical comparisons made here. The intermediate Middle Jurassic dikes (c. 172-168 Ma, whole-rock K-Ar ages, López de Luchi and Rapalini, 1997, 2002) located in the area between Gastre and Ingeniero Jacobacci (Fig. 1), although they were ascribed to Lonco Trapial Formation by those authors, were not included in the geochemical comparisons made in this study, as they could represent another younger volcanic unit.

Further north, within the Neuquén Basin, the volcanic rocks of the Precuyano cycle (Gulisano et al., 1984), which is composed of the Sañicó, Piedra del Águila and Lapa formations (Franzese et al., 2006; D'Elia et al., 2012, D'Elia et al., 2015; Benedini and Gregori, 2012, 2013) can be correlated with the volcanic deposits of Lonco Trapial and Garamilla. An U-Pb zircon age of c. $191 \mathrm{Ma}$ was obtained for a felsic tuff belonging to the Piedra del Águila Formation by Spalletti et al. (2010). The Early Jurassic volcanic rocks described by Benedini and Gregori (2013) in the Piedra del Águila area belong to the southern border of the Neuquén Basin. They are of similar age but were not considered in the comparisons of this work (c. $187 \mathrm{Ma}, \mathrm{U}-\mathrm{Pb}$ zircon age, Benedini and Gregori, 2013). Further north, within the domain of the Neuquén Basin, Early Jurassic andesites show U-Pb zircon ages of 199.0 \pm 1.5 Ma as well as inherited Late Triassic and Permian zircon ages (Schiuma and Llambías, 2008). These samples were not included in the direct comparisons of this work because they belong to the Precuyano deposits, which were deposited in another morphostructural domain. The Precuyano deposits continue in the north of Neuquén Basin at c. $38-39^{\circ} \mathrm{S}$ with the Milla Michicó, Cordillera del Viento and Nacientes del Biobío formations (De La Cruz and Suárez, 1997; Llambías et al., 2007). Also, in the northern Cordillera del Viento area, a volcano-sedimentary sequence assigned to the Colomichicó Formation is composed of basic to intermediate and felsic volcanic rocks that yielded U-Pb SHRIMP zircon ages c. 188-181 Ma belonging to the Precuyano cycle (Zappettini et al., 2011, 2018). A volcanic sequence of andesitic to dacitic composition close to the Dorsal de Huincul was dated by U-Pb in zircon c. 203-199 Ma (Schiuma and Llambías, 2008) (Fig. 1) and was therefore considered to be slightly older than the Precuyano cycle of the Neuquén Basin.

Towards the east at the present Atlantic coast (eastern domain in Fig. 1), the central belt of andesitic to rhyolitic rocks known as Lonco Trapial-Garamilla formations as described above are coeval with the eruption of the predominantly felsic volcanic rocks of the Early Jurassic Marifil Formation (Malvicini and Llambías, 1972) or Marifil Complex (Cortés, 1981). The beginning of this volcanism could be considered as marked by the intrusion of trachyandesitic and rhyolitic dikes near the Sierra Grande area (González et al., 2014, 2016, 2017). These dikes have a Middle Triassic U-Pb SHRIMP zircon age of $243.6 \pm 1.7 \mathrm{Ma}$ (González et al., 2014). In addition, trachytic lava flows associated with these dikes were dated in 247.22 $\pm 0.146 \mathrm{Ma}$ (U-Pb LA-MC-ICPMS zircon age, González et al., 2017). This Middle Triassic episode of volcanism is linked with a postorogenic extension related to changes in the SW margin of Gondwana after the Gondwanide Orogeny (González et al., 2014, 2016, 2017). Extensional volcanism is marked by the formation of the Marifil Complex, which largely consists of thick (25-100 m) flat lying, strongly welded pink or red ignimbrite units and lesser rhyolite lava flows. Tuffs, lapilli-tuffs and volcanic agglomerates are interbedded with the ignimbrites, and the sequence is intruded by sub-volcanic intrusions, including dacitic and andesitic dikes and basalt lavas which are all co-magmatic with the ignimbrites (Rapela and Pankhurst, 1993). The Rb-Sr whole-rock age of the Marifil Complex is constrained to the Early Jurassic $(182.6 \pm 1.5$ to $178.4 \pm 1.3 \mathrm{Ma}$, Rapela and Pankhurst (1993)), the isochrons are defined by rhyolites, 


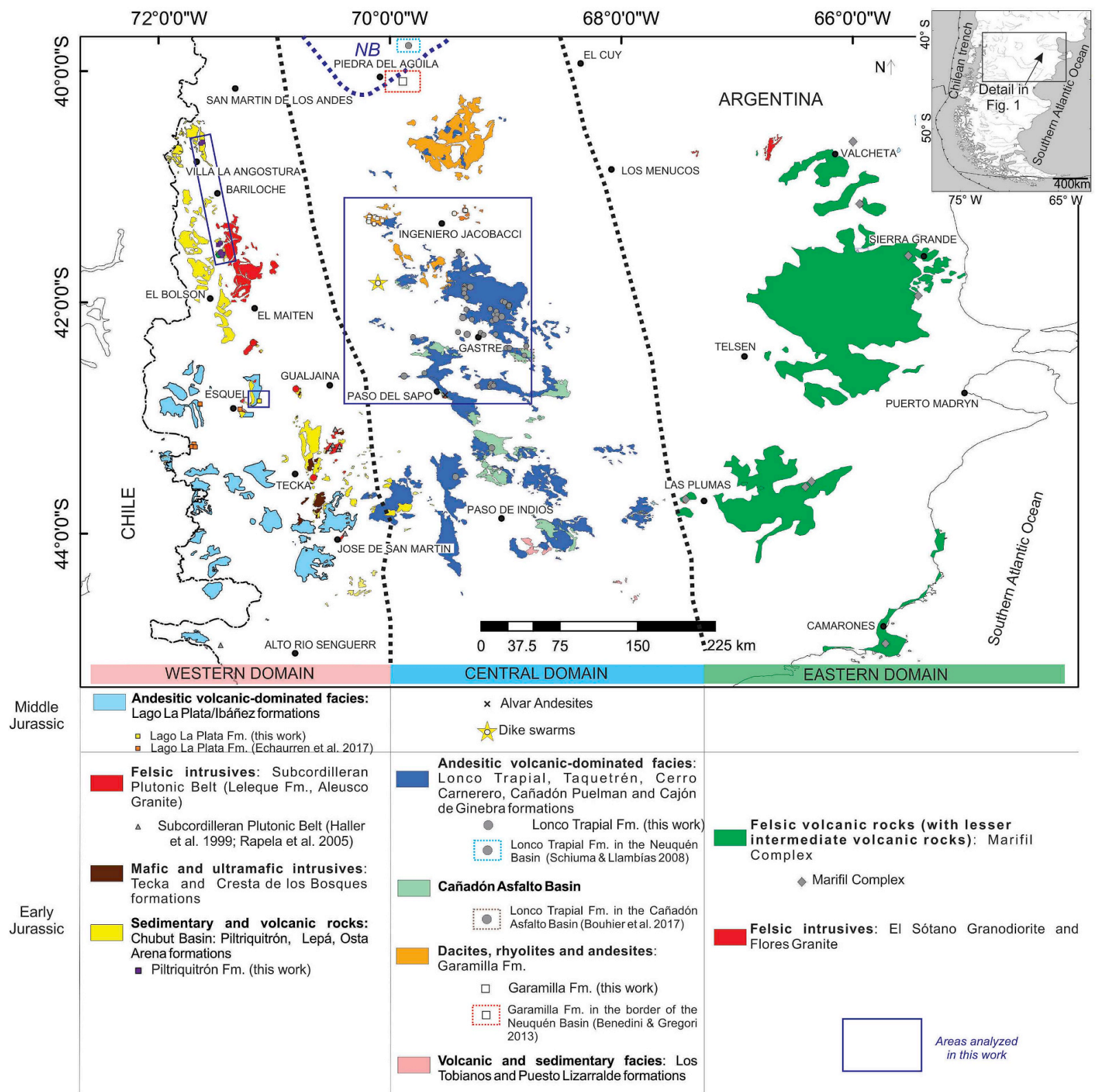

Fig. 1. Distribution of Early-Middle Jurassic rocks in northern Patagonia. The mapping has been made compiling unpublished data from the Servicio Geológico Minero Argentino (SEGEMAR), Cúneo et al. (2013), Proserpio (1978), Sato et al. (2004) and Benedini and Gregori (2013). The map shows the location of the samples with geochemical analyses from different authors which were used to make regional comparisons. Lonco Trapial Formation (Dejonghe et al., 2002; Zaffarana et al., 2018; Bouhier et al., 2017; Schiuma and Llambías, 2008), Garamilla Formation (Benedini and Gregori, 2013), Alvar Andesites (Aragón et al., 2000), the Middle Jurassic dike swarms (López De Luchi and Rapalini, 2002), Marifil Complex (Pankhurst and Rapela, 1995; Márquez et al., 2010, 2011; Navarrete et al., 2019 and Pavón Pivetta et al., 2019), the Subcordilleran Plutonic Belt (Haller et al., 1999; Rapela et al., 2005) and Lago La Plata Formation (Echaurren et al., 2017) were the units that are discussed in this work, see the text for further explanations.

trachydacites and basalts. Further $\mathrm{Rb}-\mathrm{Sr}$ isochrons performed by Pankhurst and Rapela (1995) yielded $188 \pm 1 \mathrm{Ma}, 174 \pm 2$ Ma and $169 \pm 2 \mathrm{Ma}$ for rhyolites and andesites. Additional ${ }^{40} \mathrm{Ar}-{ }^{39} \mathrm{Ar}$ results of Alric et al. (1996) also date extensional volcanism of the Marifil Complex within c. 187 and c. $176 \mathrm{Ma}$ (age determinations were made in sanidine, plagioclase and biotite coming from rhyolites, andesites and basalts). In particular, coeval ${ }^{40} \mathrm{Ar}-{ }^{39} \mathrm{Ar}$ ages were obtained for a basalt and for a felsic tuff from the Chubut river area near Las Plumas (Fig. 1, $176.9 \pm 1.6 \mathrm{Ma}$ for the basalt and $178.5 \pm 1.2 \mathrm{Ma}$ for the tuff, Alric et al., 1996), thus showing that these volcanic products are comagmatic. Intrusive facies associated with the Marifil Complex were also recognized and comprised within the Aguada del Bagual Formation by Cortés (1981). Additional intrusive rocks are the Flores Granite (Rb-Sr c. $188 \mathrm{Ma}$, Pankhurst et al., 1993) and the El Sótano Granodiorite (c.
186 Ma, U-Pb, -Sato et al., 2004). Recently Pavón Pivetta et al., 2019 proposed that the initial stages of the volcanism of the Marifil Complex are associated to subduction, whereas the second stage is related to continental rifting. A rhyolitic tuff belonging to the first stage was dated by $\mathrm{U}-\mathrm{Pb}$ in zircon at $192.6 \pm 2.5 \mathrm{Ma}$. The first stage was called V0 by the authors, and this age was also supported by the $\mathrm{U}-\mathrm{Pb}$ zircon age of $193.4 \pm 3.1$ Ma obtained by Strazzere et al. (2019) for trachytic lavas of the Marifil Complex, and the age of $190.6 \pm 3.2$ Ma for a subvolcanic body of rhyolitic composition by Strazzere et al. (2017).

In turn, towards the west, Early Jurassic intrusions form epizonal granitic bodies that crop out in the Patagonian Precordillera, an area located to the east of Patagonian Andes between $41^{\circ} 30^{\prime}$ and $44^{\circ} 30^{\prime} \mathrm{S}$ (western domain of northern Patagonia, Fig. 1). These granites comprise part of the "Sub-Cordilleran Patagonian Batholith" of Gordon and 
Ort (1993) due to their Early Jurassic age and NNW-SSE elongation, slightly oblique to the axis of the N-S Patagonian Batholith (Early Jurassic-Pleistocene; Pankhurst et al., 1999; Rolando et al., 2002; Castro et al., 2011a). The belt was renamed as "Subcordilleran Plutonic Belt" by Haller et al. (1999) on the grounds that a single continuous body is not observed. In the northern part of the belt, the Subcordilleran igneous bodies intrude foliated granites and metamorphic rocks of Paleozoic age (Rapela et al., 2005), whereas in the southern part of the belt they intrude Late Paleozoic sedimentary rocks (Tepuel Group, Suero, 1948) and are contemporary with the development of the marine sedimentary rocks (Lepá-Osta Arena formations, Herbst, 1966; Rolleri, 1970) of the Chubut Basin (Suárez and Márquez, 2007). The Subcordilleran Plutonic Belt is composed of zoned plutons dominated by Itype biotite-hornblende granodiorite and quartz monzodiorite and biotite monzogranite, with minor diorite and leucogranite (Spikermann et al., 1988, 1989; Gordon and Ort, 1993; Busteros et al., 1993; Haller et al., 1999) and also gabbros (Cresta de los Bosques-Tecka formations, Freytes, 1971; Franchi and Page, 1980; Turner, 1983). The Subcordilleran Plutonic Belt has Early Jurassic U-Pb SHRIMP zircon ages $(181 \pm 2 \mathrm{Ma}, 181 \pm 3 \mathrm{Ma}, 185 \pm 2 \mathrm{Ma}$ and $182 \pm 2 \mathrm{Ma}$, Rapela et al., 2005). The Toarcian arc-related basalts of the Icalma Formation of the Nacientes del Biobío Group is regarded as the continuation to the north of the magmatic arc represented by the Subcordilleran Plutonic Belt (De La Cruz and Suárez, 1997; Suárez and Emparan, 1995; Suárez and Márquez, 2007).

The across-arc alignment of Cordilleran suites of Mesozoic plutonic rocks in Patagonia is not common, even considering the whole Andes (Rapela et al., 2005). The NW-SE Late Triassic Central Patagonian Batholith departs considerably from the typical N-S Andean arrangement, while the NNW_SSE Early Jurassic Subcordilleran Plutonic Belt extended for more than $300 \mathrm{~km}$ immediately to the east of the North Patagonian Cordillera. The typical 180-190 Ma ages of the Subcordilleran Plutonic Belt have not been found in the Late JurassicTertiary Patagonian Batholith, strongly indicating that the NNW-SSE Subcordilleran Plutonic Belt was the axis of the arc in Early Jurassic times. Rapela et al., 2005(and references therein) suggested that the oblique axes of the Mesozoic Cordilleran granites involved a westerly migration and clockwise rotation of the arc, and in turn differential rollback of the subducted slab and associated opening of back-arc basins.

The Early Jurassic plutonism is a volumetrically major event compared to those magmatic individual pulses that made the Patagonian batholith. This latter body is huge (probably the largest Cordilleran batholith of the world) because of its protracted Late Jurassic to Pleistocene age (Pankhurst et al., 1999; Rolando et al., 2002; Castro et al., 2011a). There are sectors of the Subcordilleran Plutonic Belt still poorly studied, such as the Pilcaniyeu and Nahuel Huapi areas (SHRIMP $\mathrm{U}-\mathrm{Pb}$ zircon age of $184 \pm 2 \mathrm{Ma}$, Hervé et al., 2018). In the Antarctic Peninsula, Riley et al. (2016) reported Early Jurassic plutons to correlate with the Subcordilleran Plutonic Belt.

Near the area of Esquel and El Bolsón (Fig. 1), the Chubut Basin is represented by pyroclastic beds with subordinate basaltic lava flows and sedimentary strata known as the Piltriquitrón Formation (Lizuaín, 1980, 1999; Suárez and Márquez, 2007). This formation is mainly exposed in the area of El Bolsón and Esquel, at ca. $42^{\circ} \mathrm{S}$ (Fig. 1). The upper volcanic sequences of the Piltriquitrón Formation could be correlated with the Early-Middle Jurassic Lago La Plata Formation (Lizuaín, 1980, Fig. 1) which crops out even further to the west (Fig. 1). The Lago La Plata Formation constitutes a volcanic association of dacitic-rhyolitic ignimbrites, lithic-rich tuffs, ash-fall deposits, breccias, felsic domes and tuffs, subordinate basaltic-andesitic lavas and minor sedimentary intercalations (Haller and Lapido, 1982; Niemeyer and Skarmeta, 1984; Bruce et al., 1991; Suárez et al., 2009; Echaurren et al., 2017). Geographically, Lago La Plata volcanic rocks cover an area from Esquel in the north to Alto Rio Senguerr in the south (Fig. 1). At $42^{\circ}-43^{\circ}$ $\mathrm{S}$, radiometric dating constrains the age of the Lago La Plata Formation to c. 180-152 Ma (c. $171 \mathrm{Ma}, \mathrm{K} \_A r,-H a l l e r$ and Lapido, 1982; c. 152
Ma, K_Ar, Lizuaín, 1983; c. 160 Ma, K_Ar, -Linares and González, 1990; c. $180 \mathrm{Ma}, \mathrm{Rb} \_\mathrm{Sr}$, -Ghiara et al., 1999 and c. $170 \mathrm{Ma}, \mathrm{U} \_\mathrm{Pb},-B l e s a$, 2004), therefore partially contemporaneous with the oldest ages of the North Patagonian Batholith near the Bariloche area $\left(41^{\circ}\right.$ S, c. $170 \mathrm{Ma}$, U_Pb SHRIMP zircon age, Castro et al., 2011a) and with the youngest ages of the Subcordilleran Plutonic Belt and of Lonco Trapial and Garamilla formations. The Lago La Plata Formation was described as syn-extensional (Echaurren et al., 2017) related to an arc environment (Haller and Lapido, 1982; Lizuaín, 1999; Massaferro, 1999; Echaurren et al., 2017).

\section{Samples and analytical techniques}

Petrographic analysis was made based on $\sim 70$ thin sections from the Lonco Trapial, Garamilla, Piltriquitrón and Lago La Plata formations. Geochemical sampling was directed to complement pre-existing data, filling gaps in their spatial distribution. This work presents a total of 92 whole-rock geochemical samples from Early-Middle Jurassic volcanic units from northern Patagonia: 71 samples from Lonco Trapial Formation in the area comprised within Ingeniero Jacobacci and Paso del Sapo (Fig. 1), 11 samples from Garamilla Formation near the Ingeniero Jacobacci area (Fig. 1), 5 samples from the Lago La Plata Formation at the Cordón de Esquel area, which complement the sampling carried out by Echaurren et al. (2017) at the Cordón de Los Galeses, Cerro La Cruz and Cordón Situación areas (western domain of northern Patagonia, Figs. 1) and 5 samples of Piltriquitrón Formation between San Martín de los Andes and El Bolsón (Fig. 1).

Whole-rock major and trace elements were determined using ICP, ICP-MS, ICP-AES and XRF in five different laboratories: at the Activation Laboratories Ltd. (Actlabs) in Ancaster, Ontario (Canada), at the Acme Analytical Laboratories (Acmelabs) in Vancouver (Canada), at the SGS laboratory (Peru), at the "Jaume Almera" Institute (ICTJA, CSIC), Barcelona (Spain) and at the Technical-Scientific Services of the University of Oviedo (Spain) coupled with the Laboratories of the Geological Survey of Spain (IGME). Results are shown in Table 1-Appendix and the specifications of each laboratory are presented in the Appendix.

This work also presents new geochronological and isotopic data from Lonco Trapial Formation near Gastre (Fig. 1): 1) a new laser ablation ICP/MS U-Pb zircon age of a rhyolite dike (sample G4-231) which was performed at Actlabs (Canada), and 2) five new $\mathrm{Rb}-\mathrm{Sr}$ and $\mathrm{Sm}-\mathrm{Nd}$ determinations of amphibole separates which were done at the GZG, University of Göttingen (Germany); the results are shown in Table 1 and the analytical methods are described in the Appendix.

\section{Field and petrographic descriptions}

Field and petrographic descriptions of the Early-Middle Jurassic volcanic rocks from the central and western domain of northern Patagonia are presented below.

\subsection{Central domain of northern Patagonia}

The Early-Middle Jurassic deposits of the central domain of northern Patagonia are a complex association of intermediate and felsic volcanic rocks, together with some sedimentary intercalations. The felsic and intermediate rocks are roughly coeval, although their stratigraphic relationship is not always clear. At the north, in the area comprised within Ingeniero Jacobacci and Gastre (Figs. 1, Fig. 2a-f), this volcanism is generally ascribed to the Lonco Trapial Formation when the composition of the volcanism is mostly intermediate to silicic (Fig. 2a-b), and as Garamilla Formation when the volcanism is mostly of felsic composition (Fig. 2c-f). In contrast, around Gastre (Fig. 1), both the intermediate and the felsic volcanic rocks are included in Lonco Trapial Formation. In the Gastre area, the felsic volcanic rocks are less abundant than in the northern Ingeniero Jacobacci area. In the 
Intermediate and felsic volcanic rocks from the Ingeniero Jacobacci area (Lonco Trapial and Garamilla formations)

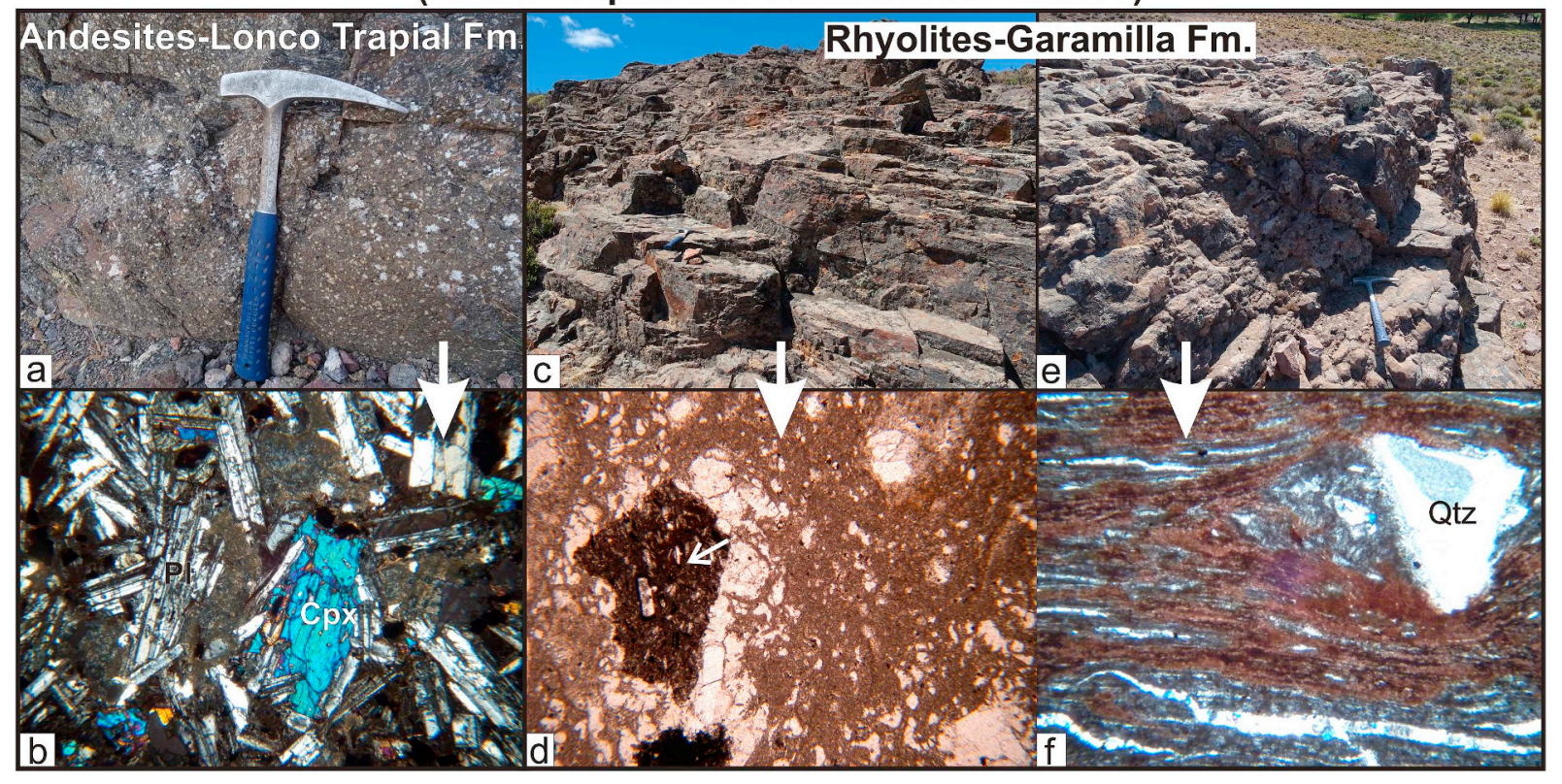

Intermediate and felsic volcanic rocks from the Gastre area (all comprised within Lonco Trapial Formation)
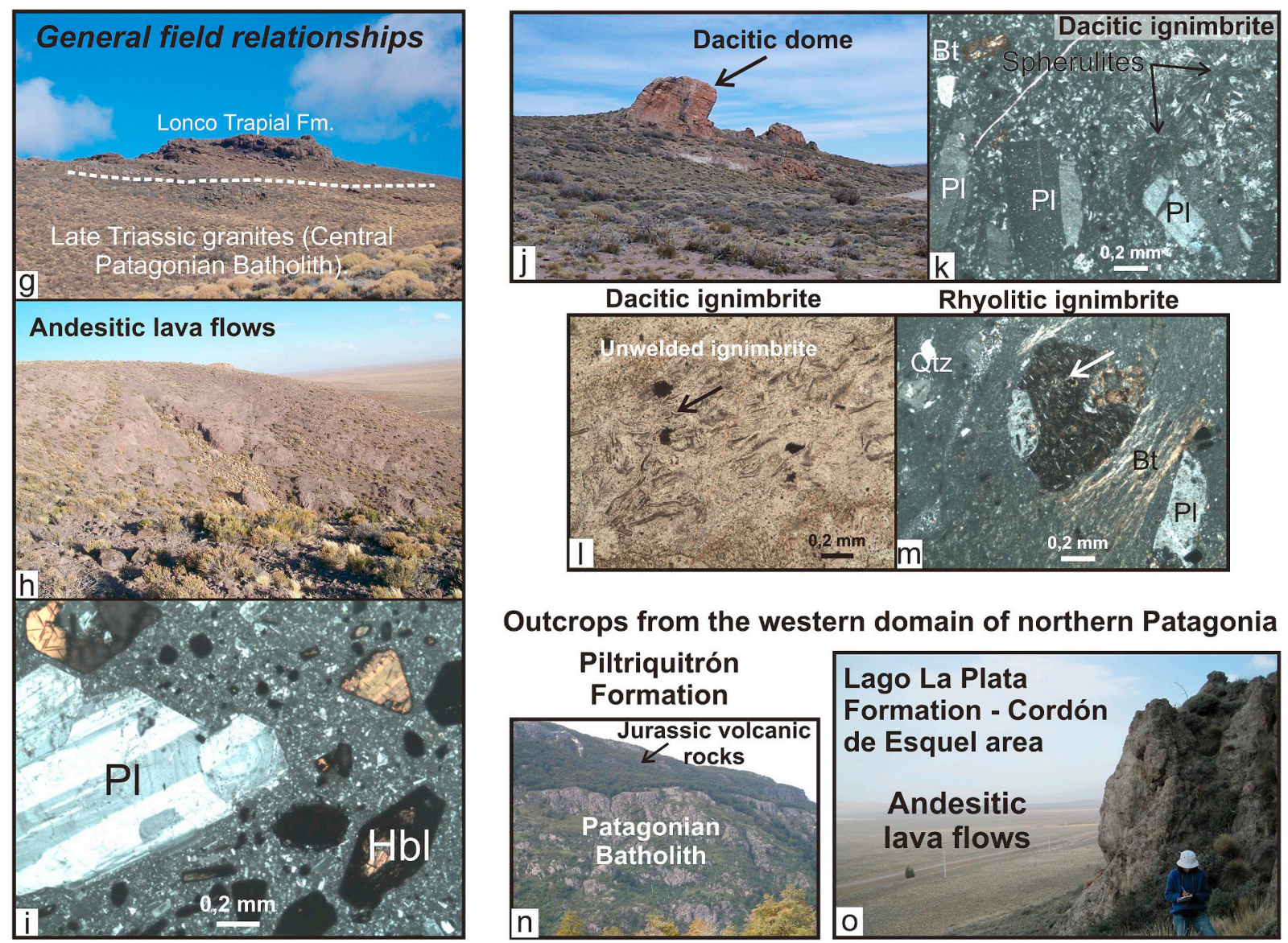

Outcrops from the western domain of northern Patagonia
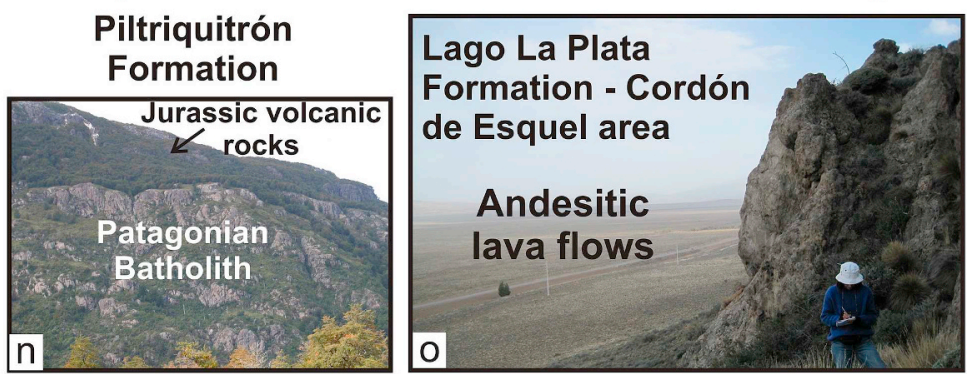

(caption on next page) 


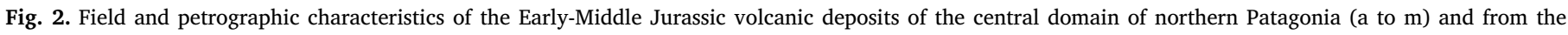

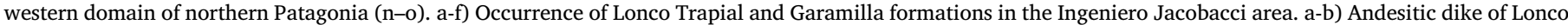

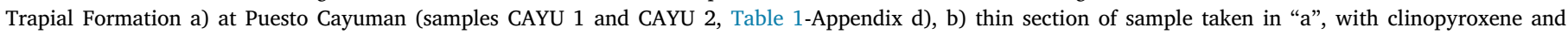

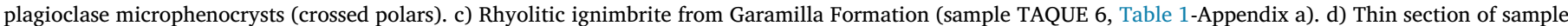

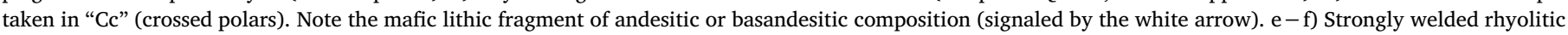

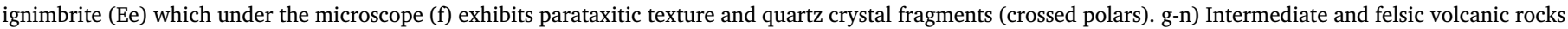

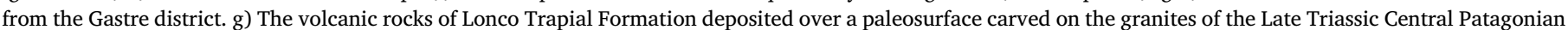

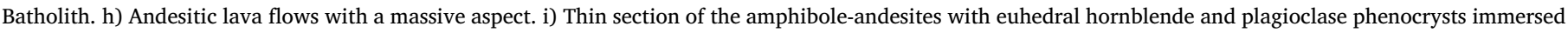

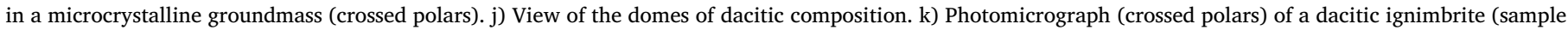

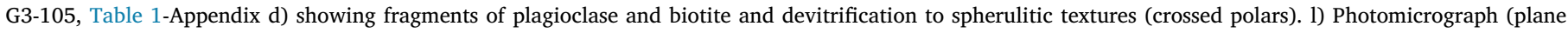

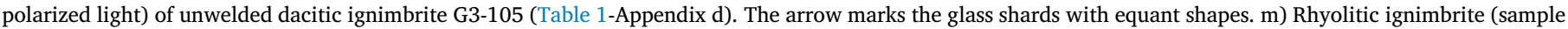

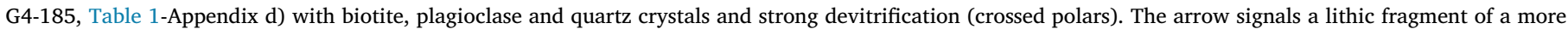

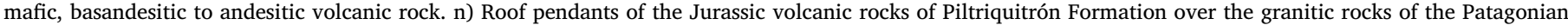

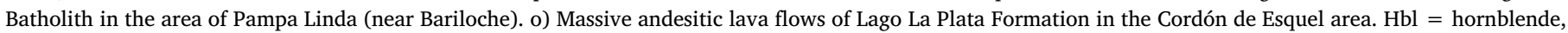
$\mathrm{Pl}=$ plagioclase, $\mathrm{Qtz}=$ quartz, $\mathrm{Bt}=$ biotite, $\mathrm{Cpx}=$ clinopyroxene.

latter area, the felsic volcanic rocks can be either below or above the intermediate rocks, and the rhyolitic ignimbrites frequently have lithoclasts of more mafic composition, typically andesitic or basandesitic (Fig. 2d, m). The U-Pb age of the felsic rocks assigned to Garamilla Formation and dated in c. 188 Ma by Franzese et al. (2002) is representative of this area; it shows that the rhyolites and the andesites broadly have the same age.

In the Gastre area (Fig. 1), the Early-Middle Jurassic volcanic rocks of Lonco Trapial Formation overlie the Late Triassic granites of the Central Patagonian Batholith (Fig. 2g; Rapela et al., 1992; Zaffarana et al., 2014). There, the Lonco Trapial Formation is represented by scarce basaltic lava flows, and by very abundant basaltic andesite to andesitic lava flows (Fig. 2h), volcanic breccias, porphyries and dikes. The most felsic rocks are dacitic lavas, domes and ignimbrites, as well as rhyolitic domes, ignimbrites and dikes (Fig. 2j-m). Generally, in the Gastre area, the felsic volcanic rocks are observed lying above the intermediate volcanic rocks, and consequently andesite fragments are found in the rhyolitic to dacitic ignimbrites (Fig. $2 \mathrm{~m}$ ). In the same way, rhyolitic dikes as well as domes intrude andesitic lavas and breccias. Potentially, a few of the domes could be Early Jurassic or even older. Further south, in the area comprised between Las Plumas and Paso de Indios (Fig. 1), the interbedding of two facies (felsic and intermediate) was recorded by Sacomani et al. (2007). The petrographic description of the main lithologies of the Lonco Trapial and Garamilla formations is presented below. The descriptions are organized from less evolved to more evolved rocks, regardless of their classification as part of the Lonco Trapial or Garamilla formations, which is mostly geographical, as well as lithological.

Lava flows of basaltic compositions are rare in the Early-Middle Jurassic volcanic deposits of the central domain of northern Patagonia. When present, they are ascribed to Lonco Trapial Formation. They have porphyritic texture with $40 \%$ phenocrysts of plagioclase immersed in a groundmass with intergranular texture composed of plagioclase $(60 \%)$, clinopyroxene (25\%), olivine (10\%) and opaque minerals and apatite $(<5 \%)$. Olivine phenocrysts are altered to saponite or iddingsite. Basaltic andesite dikes and lava flows have ophitic to subophitic texture, with plagioclases partially immersed in light green to colorless pleochroic clinopyroxene, interstitial opaque minerals, and interstitial glass altered to sericite and clays. Andesitic lavas, breccias, porphyries and dikes are the most abundant volcanic rocks of the Jurassic volcanic association of northern Patagonia, and they are typically comprised within Lonco Trapial Formation. The andesites can be of two types, according to the association of phenocrysts: clinopyroxene-andesites (as the ones of Fig. 2b), which have clinopyroxene as the main mafic mineral, and amphibole-andesites, whose principal mafic mineral is amphibole (Fig. 2i). Amphibole-andesites are more common. Both andesite types are porphyritic to glomeroporphyritic, with up to $30 \%$ phenocrysts.

Plagioclase phenocrysts are euhedral to subhedral, comprise $40-60 \%$ of the phenocryst phase and can be up to $3 \mathrm{~mm}$ in size. They commonly display optical zoning, signs of resorption and disequilibrium margins, sieve textures and inner albitic rings. Altered and fresh plagioclase crystals and sieved as well as uncorroded crystals often coexist in the same sample. Clinopyroxene-andesites contain $\sim 20 \%$ of small euhedral clinopyroxene phenocrysts. Clinopyroxene can be augite (Zaffarana et al., 2018) or Ti-augite. Coexisting amphibole occurs only as brown and pleochroic micro-phenocrysts. In the amphibole-andesites, instead, amphibole is subhedral light green to brown pleochroic with occasional thin rims rich in $\mathrm{Fe}-\mathrm{Ti}$ oxides from decompression reactions. Polysynthetic twinning in amphiboles (mostly hornblende and tschermakite, Zaffarana et al., 2018) and compositional zoning is common. In some samples, amphibole may occur as redbrown oxy-hornblende. Amphibole crystals occasionally are resorbed; relict clinopyroxene cores are observed in some cases as well. Where present, biotite is brown to reddish pleochroic, with rutile inclusions and may be altered to iron oxides. Other accessory minerals such as titanomagnetite, titanite and apatite are present in both andesite types as small crystals in the groundmass. Euhedral, stubby apatite crystals are present either as isolated crystals or as inclusions in plagioclase phenocrysts. Groundmass textures of the andesites are microcrystalline, sometimes intergranular, intersertal, trachytic, pilotaxitic or hyalopilitic, composed of microliths of the same mineral assemblages than the phenocrysts. Interstitial glass is commonly replaced by sericite and clays. A moderate propylitic alteration (chlorite, carbonate, secondary titanite, quartz, epidote, albite and opaque minerals) is common in the andesites.

The felsic volcanic rocks can be included either in Garamilla Formation when they are more voluminous (as in the Ingeniero Jacobacci area) or they may be considered part of Lonco Trapial Formation when they are volumetrically less important (as in the Gastre area). The dacitic lavas and domes (generally included in Lonco Trapial Formation, Fig. 2j) are porphyritic to glomeroporphyritic, with 70 to $40 \%$ of phenocrysts of plagioclase, biotite and quartz, and sometimes also orthoclase, amphibole and clinopyroxene. Zircon and opaque minerals are found as accessory mineral phases. The groundmass is either totally composed of devitrified glass, or is fine-grained felsitic, microcrystalline, to trachytic or pilotaxitic. The dacitic ignimbrites can be welded or unwelded (Fig. 2l) and exhibit crystal fragments of quartz, orthoclase, hornblende, biotite and opaque minerals (Fig. 2k). The glass shards of the groundmass are partly to completely devitrified.

The rhyolitic ignimbrites are often densely welded with parataxitic and eutaxitic textures (e.g. in the Garamilla Formation, Fig. 2f). Crystal fragments are of quartz, orthoclase, plagioclase, biotite and opaque minerals (Fig. 2m). Lithic fragments are common and comprise andesites or basaltic andesites (Fig. 2d) and felsic plutonic rocks (derived from granites exposed directly below the volcanic deposits, Fig. $2 \mathrm{~g}$ ). The pyroclastic deposits are always strongly devitrified to spherulitic, axiolitic and felsitic textures. Secondary minerals such as epidote, titanite, chlorite, sericite, clays, and carbonate are frequently found replacing mafic minerals and matrix. The rhyolitic domes have 


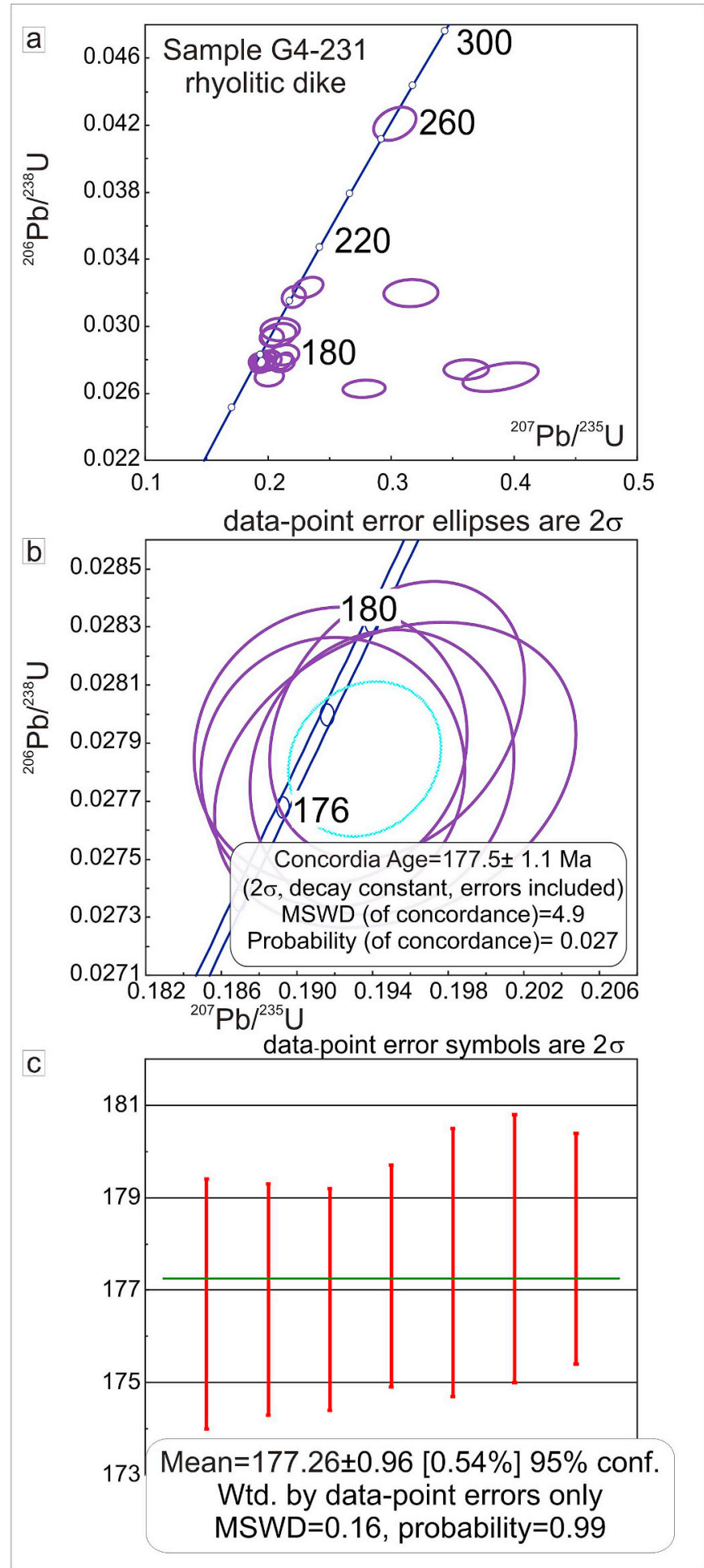

Fig. 3. U-Pb zircon age of sample G4-231, a rhyolite dike cropping out around Los Manantiales district, near Gastre (Lagorio et al., 2018). a) Concordia diagram of zircons analyzed from the sample. Ellipses denote $2 \sigma$ uncertainty of single zircon analyses. b) Detail of "a", showing a concordia age of $177.5 \pm 1.1 \mathrm{Ma}$. c) Age distribution plot of the sample giving an age of $177.26 \pm 0.96 \mathrm{Ma}$. MSWD: mean square of weighted deviates.

porphyritic texture with $30 \%$ of phenocrysts (quartz, orthoclase and biotite) in a microcrystalline groundmass. Quartz typically shows bipyramidal shape with dissolution embayments and biotite is often altered to opaque minerals and chlorite. The rhyolitic dikes have porphyritic textures, with phenocrysts $(2 \%)$ of plagioclase and alkali feldspar, with slight sericitic and clay alteration respectively, and minor biotite with zircon inclusions. Their groundmass is mainly composed of quartz and feldspar, mostly spherulitic as a devitrification product, with scarce carbonate alteration.

\subsection{Western domain of northern Patagonia}

The Piltriquitrón Formation was characterized by Lizuaín (1980) as an alternating series of sedimentary and volcanic rocks. Sedimentary rocks are sandstones, pelites, conglomerates and scarce limestones. The volcanic rocks are lava flows, breccias and tuffs of andesitic, dacitic and rhyodacitic composition (Lizuaín, 1980). Volcanic rocks are more abundant than sedimentary rocks (Giacosa and Heredia Carballo, 2001) and both are intruded by the Patagonian Batholith, forming numerous roof pendants (Fig. 2n; Giacosa and Heredia Carballo, 2001). The rhyodacitic lavas have porphyritic texture and are composed of quartz, plagioclase and K-feldspar phenocrysts within a gray-coloured aphanitic groundmass (Giacosa and Heredia Carballo, 2001). Andesitic rocks are compositionally very similar to tonalites and granodiorites of the Subcordilleran Plutonic Belt Giacosa and Heredia Carballo (2001), therefore the andesites could represent a related eruptive activity. The andesitic rocks frequently show hydrothermal alteration and sulphide veins (Giacosa, 1986).

The samples of Piltriquitrón Formation gathered for this work in the area comprised within San Martín de Los Andes and El Bolsón are andesites, dacites and rhyolites. All rock types are variably altered to a propylitic mineral assemblage. The andesites are composed of amphibole and plagioclase phenocrysts. Plagioclases have sieve textures and are altered to sericite and clays. Mafic minerals (amphibole and biotite) are altered to opaque minerals and to carbonate, epidote and chlorites.

The Early-Middle Jurassic Lago La Plata Formation at the Cordón de Esquel area, in western Patagonia domain (Fig. 1) is composed of massive andesitic lava flows of greenish color (Fig. 2n). These have porphyritic to glomeroporhpyritic texture and are composed of phenocrysts of plagioclase $(60 \%)$, clinopyroxene $(15 \%)$, amphibole $(10 \%)$, olivine (5\%), opaque minerals $(5 \%)$ and a $5 \%$ consisting of biotite and apatite. The phenocrysts are immersed in a groundmass of pilotaxitic to trachytic texture (sometimes intersertal) composed of partially oriented micron-sized plagioclase microliths, opaque minerals and abundant glass. The glass may be dark or light brown under plane polarized light, with irregular contacts between light and dark glass. Phenocrysts comprise $30-40 \%$ of the rock.

Plagioclase is euhedral to subhedral, with sieve texture and compositional zoning. Clinopyroxenes are subhedral to euhedral phenocrysts, they are light brown, slightly pleochroic and have coloured growth bands from compositional zoning. Inclusions of opaque minerals and of acicular apatite occur. The amphibole is completely replaced by chlorite. Olivine is present as inclusions in plagioclase and clinopyroxene. Opaque minerals are euhedral, with cubic shaped crystals. Biotite crystals are very scarce and pleochroic from light to dark brown. The groundmass is altered to a propylitic assemblage of carbonates, chlorites and clays. Vesicular textures are also common, and vesicles are filled with quartz and chlorites.

\section{Geochronology}

The age determination of a rhyolitic dike of Lonco Trapial Formation located at $42^{\circ} 3^{\prime} 39,6^{\prime \prime} \mathrm{S}-69^{\circ} 9^{\prime} 39,9^{\prime \prime} \mathrm{W}$ is presented here (sample G4-231). This dike is located near the Los Manantiales mining district, a polymetallic deposit located $12 \mathrm{~km}$ to the southwest of the Ángela mine (Lagorio et al., 2018). The rhyolitic dikes of this area have WNW, NW, NE, ENE strike and intrude a sequence of lava flows, pyroclastic rocks and breccias of andesitic composition, as well as volcaniclastic deposits assigned to the Lonco Trapial Formation. The rhyolitic dikes represented by the dated sample have a NE orientation, as well as those from Los Manantiales mining district. 
The U-Pb zircon age of the rhyolite dike of Lonco Trapial Formation (sample G4-231) is 177.26 $\pm 0.96 \mathrm{Ma}$ (Fig. 3). This Early Jurassic age coincides with the age of $178.9 \pm 1.1$ Ma obtained for an andesitic lava flow (sample G2-063) by the ${ }^{40} \mathrm{Ar}-{ }^{39} \mathrm{Ar}$ stepwise method in amphibole (Zaffarana et al., 2018). These ages are slightly younger than those of $185.4 \pm 2 \mathrm{Ma}, 185 \pm 1.6 / 184 \pm 5 \mathrm{Ma}\left({ }^{40} \mathrm{Ar}-{ }^{39} \mathrm{Ar}\right.$ in amphibole, samples T0 and T1 respectively, Zaffarana and Somoza, 2012) and of 191.6 \pm 5.2 Ma (K-Ar whole rock method, sample G3-134, Zaffarana et al., 2018) obtained for trachyandesitic and andesitic rocks from the Lonco Trapial Formation in the area of Gastre (Fig. 1). Geochemical and isotopic data from these dated samples are included in Tables 1 and 2, and they were always identified in the geochemical plots in order to constrain the evolution of the Lonco Trapial magmatism.

\section{Geochemistry}

\subsection{Major elements}

A careful selection of samples was done in order to choose the freshest and representative samples. Only samples with LOI $<3$ were plotted in the major element diagrams of Fig. 4. Lonco Trapial volcanic rocks range from basaltic andesites to trachyandesites, trachydacites and rhyolites $\left(\mathrm{SiO}_{2}\right.$ contents range from 50.89 to $80.64 \mathrm{wt} \%$, normalized to $100 \%$ on anhydrous basis) in the TAS diagram (Fig. 4a). They define a subalkaline magma series, with some samples plotting in the alkaline field (Fig. 4a). The volcanic rocks from Garamilla Formation have more restricted compositions ranging from andesites to rhyolites, all plotting in the subalkaline field in the TAS diagram (Fig. $4 \mathrm{a} ; \mathrm{SiO}_{2}$ ranges from 60.60 to $80.82 \mathrm{wt} \%$, on anhydrous basis).

The rocks from Lonco Trapial and Garamilla have a wide $\mathrm{FeO}, \mathrm{MgO}$, $\mathrm{MnO}, \mathrm{CaO}, \mathrm{TiO}_{2}$ and $\mathrm{P}_{2} \mathrm{O}_{5}$ range (Table 1-Appendix). Most major elements show negative trends with increasing $\mathrm{SiO}_{2}$ (Fig. $4 \mathrm{~d}-\mathrm{j}$ ), excepting $\mathrm{Na}_{2} \mathrm{O}$ whose contents remain constant with $\mathrm{SiO}_{2}$ up to $70 \mathrm{wt} \%$ of $\mathrm{SiO}_{2}$, where there is an inflection point, beyond which it has a negative correlation (Fig. 4i). $\mathrm{K}_{2} \mathrm{O}$ shows an increasing trend with a great scatter, showing that Lonco Trapial volcanic rocks fall between tholeiitic (lowsilica rocks) and high potassic magmas (high-silica samples, Fig. 4b). The scatter of the alkalies and in particular the high $\mathrm{K}_{2} \mathrm{O}$ and low $\mathrm{Na}_{2} \mathrm{O}$ of the samples with $\mathrm{SiO}_{2}>70 \%$ (anhydrous basis, Fig. $4 \mathrm{~b}$ and i) could be due to the alteration of the K-feldspars (e.g., Mathieu, 2018). Garamilla Formation volcanic rocks correspond to a medium-K calc-alkaline magma series ranging to shoshonitic ones (Fig. 4b). The high $\mathrm{K}_{2} \mathrm{O}$ content of Lonco Trapial volcanic rocks (except the scattered samples $>70 \% \mathrm{SiO}_{2}$ ) reflect calc-alkaline and alkali-calcic affinities (Page and Page, 1993).

In the aluminous index diagram of Shand (1943), the intermediate rocks from Garamilla and Lonco Trapial formations are metaluminous and peraluminous, and the high-silica rocks of both units $\left(\mathrm{SiO}_{2}>70 \%\right)$ are mostly peraluminous (Fig. 4c). It is important to note that the ASI index of the rocks of Lonco Trapial increases with decreasing age, as the sample G3-134 of $\sim 192$ Ma has lower ASI index (ASI index of 0.79) than the rocks dated in $\sim 185 \mathrm{Ma}$ (T0 and T1, ASI index of 0.90 and 0.94 ) and in $\sim 177-178 \mathrm{Ma}$ (G2-063 and G4-231, ASI index of 0.96 and of 1.22 , respectively, Fig. 4c).

The Piltriquitrón Formation is represented by subalkaline basalts, basaltic andesites, dacites and rhyolites in the TAS diagram (Fig. 4a). Like the Subcordilleran Plutonic Belt, rocks of the Piltriquitrón Formation define a moderate-to high-potassium calc-alkaline magma series (Fig. 4b). They have low to high silica $\left(\mathrm{SiO}_{2} 51.53-76.63 \mathrm{wt} \%\right.$, on anhydrous basis) and $\mathrm{MgO}, \mathrm{FeO}_{(\mathrm{t})}, \mathrm{TiO}_{2}$ and $\mathrm{Al}_{2} \mathrm{O}_{3}$ contents $(0.52-6.17$, 1.04-9.23, 0.16-1.12 and 13.12-18.49 wt\%, respectively). The samples from the Subcordilleran Plutonic Belt are metaluminous, whereas some samples from Piltriquitrón Formation may be peraluminous as well (Fig. 4c).

The Lago La Plata Formation from the Cordón de Esquel area is 
Table 2

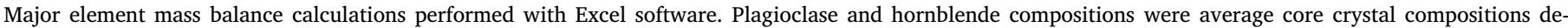

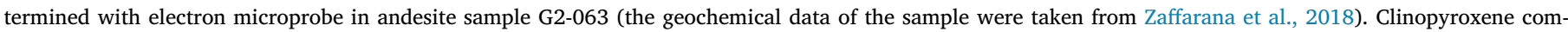

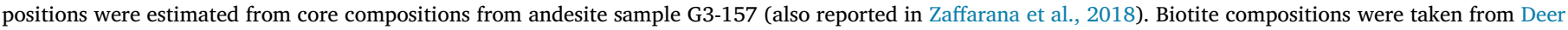
et al. (2013).

\begin{tabular}{|c|c|c|c|c|c|c|c|c|c|}
\hline & G2-63 & G2-69 & \multicolumn{4}{|c|}{ Fractionating phases } & & & \multirow[b]{3}{*}{$\operatorname{Res}^{2}$} \\
\hline & \multirow{2}{*}{$\frac{\text { andesite }}{\text { Starting composition }}$} & \multicolumn{3}{|l|}{ trachydacite } & \multirow[b]{2}{*}{$\mathrm{Cpx}$} & \multirow[b]{2}{*}{ Biotite } & \multirow[b]{2}{*}{ Melt } & \multirow[b]{2}{*}{ Calc - Obs } & \\
\hline & & Final composition & Amp & $\mathrm{Pl}$ & & & & & \\
\hline $\mathrm{SiO}_{2}$ & 61.79 & 64.98 & 43.31 & 58.26 & 51.56 & 39.87 & 65.76 & 0.78 & 0.61 \\
\hline $\mathrm{TiO}_{2}$ & 0.56 & 0.48 & 1.15 & 0.01 & 0.71 & 3.69 & 0.51 & 0.03 & 0.00 \\
\hline $\mathrm{Al}_{2} \mathrm{O}_{3}$ & 17.83 & 17.90 & 12.11 & 25.99 & 2.29 & 15.77 & 18.58 & 0.67 & 0.45 \\
\hline $\mathrm{FeO}_{\text {tot }}$ & 4.80 & 3.87 & 15.47 & 0.13 & 8.26 & 14.61 & 3.62 & -0.26 & 0.07 \\
\hline $\mathrm{MgO}$ & 3.50 & 1.65 & 12.10 & 0.01 & 15.46 & 16.02 & 1.83 & 0.18 & 0.03 \\
\hline $\mathrm{CaO}$ & 4.96 & 2.75 & 10.64 & 8.10 & 21.11 & 0.00 & 2.74 & -0.01 & 0.00 \\
\hline $\mathrm{Na}_{2} \mathrm{O}$ & 4.68 & 6.24 & 1.92 & 7.21 & 0.38 & 0.52 & 5.05 & -1.19 & 1.41 \\
\hline $\mathrm{K}_{2} \mathrm{O}$ & 1.61 & 1.89 & 0.48 & 0.21 & 0.00 & 9.47 & 1.95 & 0.06 & 0.00 \\
\hline TOT & 100.00 & 99.76 & 100.00 & 100.00 & 100.00 & 100.00 & 100.00 & 0.27 & 2.57 \\
\hline wt \% & & & 0.10 & 0.10 & 0.05 & 0.01 & & & \\
\hline$\Sigma$ res $^{2}=$ & 1.60 & & & & & & & & \\
\hline $\mathrm{F} \%=$ & 26.00 & & & & & & & & \\
\hline & $\begin{array}{l}\text { G2-69 } \\
\text { trachydacite }\end{array}$ & $\begin{array}{l}\text { G4-231 } \\
\text { rhyolite }\end{array}$ & Fraction & phases & & & & & \\
\hline & Starting composition & Final composition & Amp & $\mathrm{Pl}$ & Biotite & Melt & Calc - Obs & $\operatorname{Res}^{2}$ & \\
\hline $\mathrm{SiO}_{2}$ & 64.98 & 77.78 & 43.31 & 58.26 & 39.87 & 71.81 & -5.97 & 35.64 & \\
\hline $\mathrm{TiO}_{2}$ & 0.48 & 0.14 & 1.15 & 0.01 & 3.69 & 0.35 & 0.21 & 0.04 & \\
\hline $\mathrm{Al}_{2} \mathrm{O}_{3}$ & 17.90 & 12.63 & 12.11 & 25.99 & 15.77 & 15.28 & 2.65 & 7.04 & \\
\hline $\mathrm{FeO}_{\text {tot }}$ & 3.87 & 1.10 & 15.47 & 0.13 & 14.61 & 3.46 & 2.36 & 5.58 & \\
\hline $\mathrm{MgO}$ & 1.65 & 0.44 & 12.10 & 0.01 & 16.02 & 0.19 & -0.25 & 0.06 & \\
\hline $\mathrm{CaO}$ & 2.75 & 0.69 & 10.64 & 8.10 & 0.00 & 0.01 & -0.67 & 0.45 & \\
\hline $\mathrm{Na}_{2} \mathrm{O}$ & 6.24 & 2.38 & 1.92 & 7.21 & 0.52 & 6.71 & 4.32 & 18.68 & \\
\hline $\mathrm{K}_{2} \mathrm{O}$ & 1.89 & 4.74 & 0.48 & 0.21 & 9.47 & 2.12 & -2.62 & 6.87 & \\
\hline wt \% & & & 0.06 & 0.26 & 0.05 & & & & \\
\hline$\Sigma$ res $^{2}=$ & 8.62 & & & & & & & & \\
\hline $\mathrm{F} \%=$ & 63.00 & & & & & & & & \\
\hline
\end{tabular}

analyzed together with the data from Echaurren et al. (2017) which come from the neighbor areas of Cordón de Los Galeses, Cerro La Cruz and Cordón Situación. The samples from the Cordón de Esquel area are always comprised within the broader range depicted by the samples from Echaurren et al. (2017). At the Cordón de Esquel, the Lago La Plata Formation shows superimposed hydrothermal alteration, where the outer propylitic zone is of regional extent; this alteration is associated with the low-sulfidation epithermal deposit of Esquel (Blesa, 2004). The complete set of Lago La Plata Formation samples are alkaline and subalkaline rocks in the TAS diagram, ranging from basaltic trachyandesites, trachyandesites, andesites, dacites and rhyolites (Fig. 4a). They have a broad range of silica $\left(\mathrm{SiO}_{2} 51.31-73.49 \mathrm{wt} \%\right.$, on anhydrous basis), $\mathrm{MgO}, \mathrm{FeO}_{(\mathrm{t})}, \mathrm{TiO}_{2}$ and $\mathrm{Al}_{2} \mathrm{O}_{3}$ (5.4-0.29, 9.27-2.14, $0.98-0.29$ and $17.17-14.12 \mathrm{wt} \%$, respectively). They show a medium to high-potassium calc-alkaline affinity (Fig. 4b) and represent metaluminous to peraluminous magmas, especially the high-silica samples, which are peraluminous (Fig. 4c). Harker diagrams (Fig. 4d-j) show that at the $57-63 \%$ silica range, their oxide content is always like that of Lonco Trapial volcanic rocks.

Marifil Complex volcanic rocks fall into the alkaline and subalkaline fields in the TAS diagrams (Fig. 4a). The rocks are mostly felsic, with metaluminous to peraluminous rhyolites, trachytes and trachydacites as the most representative ones (Fig. $4 \mathrm{a}, \mathrm{c}$ ). In the variation of major elements against $\mathrm{SiO}_{2}$ they overlap in $\mathrm{TiO}_{2}, \mathrm{Al}_{2} \mathrm{O}_{3}, \mathrm{FeO}_{(\mathrm{t})}, \mathrm{MgO}$ and $\mathrm{CaO}$ with the rocks of the central and western domains of northern Patagonia.

\subsection{Trace elements}

In general, for the intermediate rocks of Lonco Trapial, Garamilla, Lago La Plata and Piltriquitrón formations, the classification of Winchester and Floyd (1977) (Fig. 5) is consistent with the TAS classification (Fig. 4a). Lonco Trapial samples plot from andesites to rhyodacites/dacites, whereas Garamilla Formation rocks plot from andesites to rhyolites. The samples from Piltriquitrón Formation are andesite/basalts to trachyandesites, and the samples from the Lago La Plata Formation plot in the limit between andesite and andesite/basalt field and in the rhyodacite/dacite field (Fig. 5).

Some differences arise when analyzing the high-silica samples of the different units $\left(\mathrm{SiO}_{2}>70 \%\right)$ in the $\mathrm{Nb} / \mathrm{Y}$ vs. $\mathrm{Zr} / \mathrm{TiO}_{2}$ diagram (Fig. 5). The rhyolites of Lonco Trapial Formation (which were identified in the TAS diagram of Fig. 4a) classify either as trachyandesites or as rhyodacites/dacites (Fig. 5) because of their low $\mathrm{Zr}$ content with respect of the rhyolites of the Garamilla Formation. The same is observed for the sample from Piltriquitrón Formation that was classified as a rhyolite in the TAS diagram (compare Fig. 4a with Fig. 5) together with the rhyolites of the Garamilla Formation and of Marifil Complex. Some rhyolites (and trachytes and trachydacites of Marifil Complex) are classified as peralkaline rhyolites (commendites/pantellerites) due to their high $\mathrm{Zr}$ content (Fig. 5). Some trachyandesites of Lonco Trapial Formation also have high $\mathrm{Nb} / \mathrm{Y}$ ratio, suggesting mildly alkaline characteristics (Fig. 5). The lower $\mathrm{Nb} / \mathrm{Y}$ ratios of the samples of Lago La Plata and Piltriquitrón formations and of the Subcordilleran Plutonic Belt are more compatible with their subduction tectonic environment (Fig. 5). 


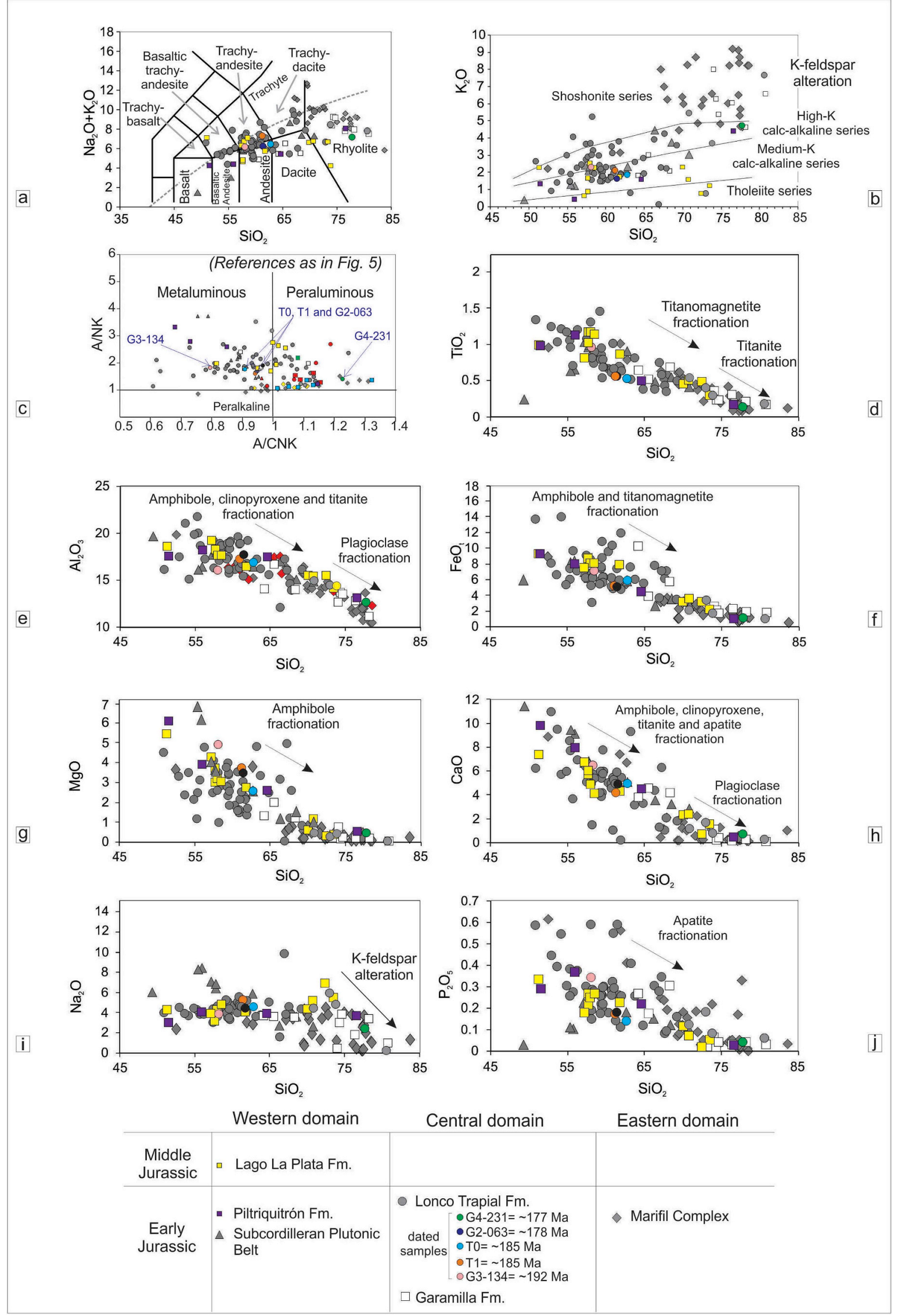

(caption on next page) 


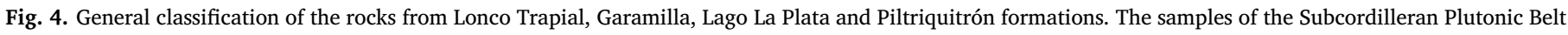

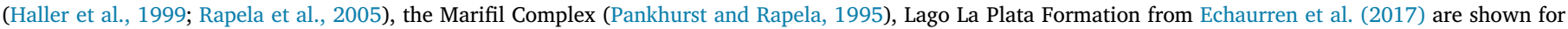

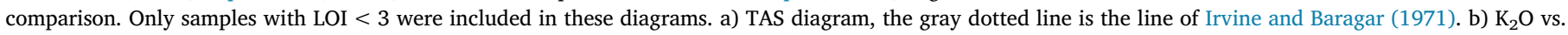

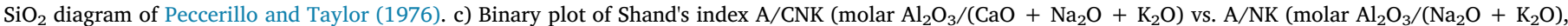

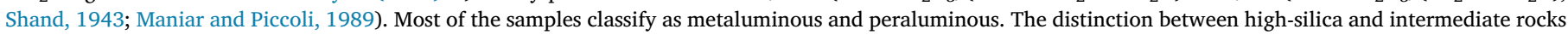
in this figure is the same as in Fig. $5 \mathrm{~d}-\mathrm{j}$ ) Harker diagrams showing some mineral fractionation trends.

\subsection{Trace element source characteristics}

A comparison of the trace element data of Early-Middle Jurassic rocks from the western, central and eastern domains of northern Patagonia is presented in Fig. 6 and differences and similarities in trace element patterns are discussed below, separating rocks with intermediate and high-silica content $\left(\mathrm{SiO}_{2}\right.$ between 57 and $63 \%$ and $\mathrm{SiO}_{2}>70 \%$, respectively). The rhyolite dominated Marifil Complex and Garamilla Formation are treated together in Fig. 6 because they are geochemically similar.

Intermediate rocks from Lonco Trapial Formation are moderately enriched in light rare earth elements, show moderate fractionation of middle rare earth elements and have small or no significant Eu negative anomalies $\left([\mathrm{La} / \mathrm{Sm}]_{\mathrm{N}}=2.21-4.61 ;[\mathrm{Gd} / \mathrm{Yb}]_{\mathrm{N}}=1.40-3.06 ; \mathrm{Eu} /\right.$ $\mathrm{Eu}^{*}=0.81-1.08$; Fig. 6a), coherent with a garnet-free source (e.g., Wilson, 2007). In the multi-elemental diagram, Lonco Trapial andesites have enrichment in $\mathrm{K}, \mathrm{Cs}, \mathrm{Rb}$, positive $\mathrm{Ba} \mathrm{Zr}$ and $\mathrm{Ti}$ spikes and $\mathrm{Nb}$ and Ta depletions compared to neighboring elements (such as La, Fig. 6b). The oldest rocks from this unit (andesite G3-134, of $\sim 192 \mathrm{Ma}$ ) are more enriched in rare earth elements, and in incompatible elements than the youngest rocks (andesite G2-63 of $\sim 178 \mathrm{Ma}$; Fig. $6 \mathrm{a}$ and b).

Felsic rocks from Lonco Trapial Formation are more enriched in light rare earth elements than the intermediate rocks from this unit, and show little fractionation of heavy rare earth elements ([La/ $\mathrm{Sm}]_{\mathrm{N}}=3.26-6.51 ;[\mathrm{Gd} / \mathrm{Yb}]_{\mathrm{N}}=1.27-1.96 ;$ Fig. 6c). They show minor to significant negative Eu anomalies (Eu/Eu* = 0.4-0.9; Fig. 4c) but generally lack depletions in $\mathrm{Ba}$ and $\mathrm{Sr}$. Negative Ti and $\mathrm{P}$ anomalies are present, although not in all the rocks (Fig. 6d).

The intermediate rocks from Garamilla Formation and the Marifil Complex have moderate enrichment in light rare earth elements, low fractionation of heavy rare earth elements and almost no negative Eu anomalies $\left([\mathrm{La} / \mathrm{Sm}]_{\mathrm{N}}=2.71-4.09 ;[\mathrm{Gd} / \mathrm{Yb}]_{\mathrm{N}}=1.92-3.82 ; \mathrm{Eu} /\right.$ $\mathrm{Eu}^{*}=0.8-0.97$; Fig. 6e). In addition, the intermediate rocks from these units show $\mathrm{Nb}$ and Ta troughs, $\mathrm{K}, \mathrm{Cs}, \mathrm{Rb}$ and $\mathrm{Ba}$ enrichment and $\mathrm{Zr}$ and $\mathrm{P}$ positive spikes (the latter are more marked in the Marifil Complex, Fig. 6f). The felsic rocks from these units are moderately enriched in rare earth elements and have flat slopes in heavy rare earth elements. It is noteworthy that they show a strong negative Eu anomaly which

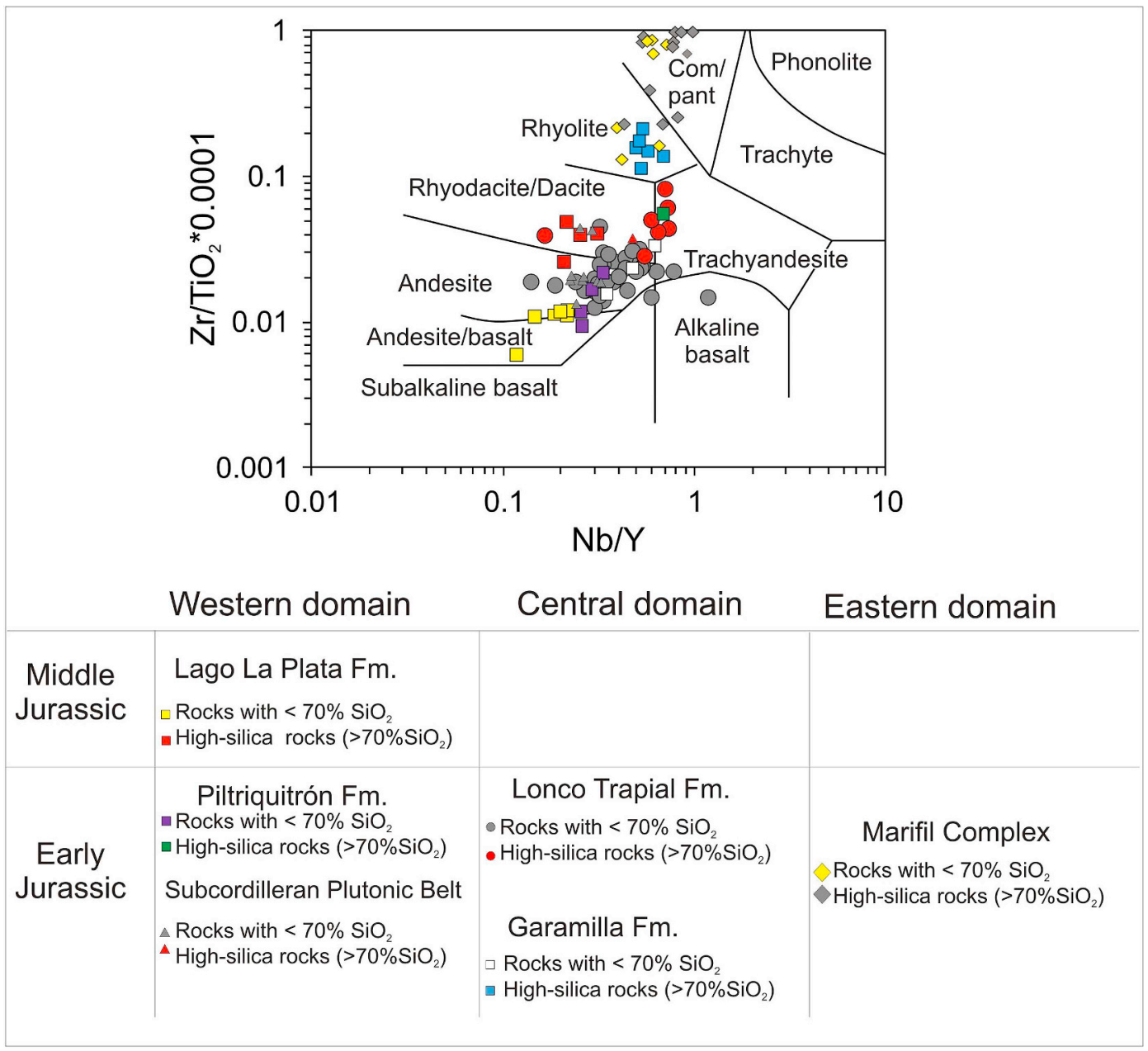

Fig. 5. Classification of Winchester and Floyd (1977) based on immobile elements. Geochemical analyses from other authors: Lago La Plata Formation (Echaurren et al., 2017), Marifil Complex (Márquez et al., 2010, 2011; Navarrete et al., 2019), the Subcordilleran Plutonic Belt (Haller et al., 1999; Rapela et al., 2005). Com/ Pant: commendites/pantellerites (peralkaline rhyolites). 
Central domain: Lonco Trapial Fm. (sequence dominated by intermediate volcanic rocks)

Intermediate rocks ( $\mathrm{SiO}_{2}$ between 57 and 63\%)

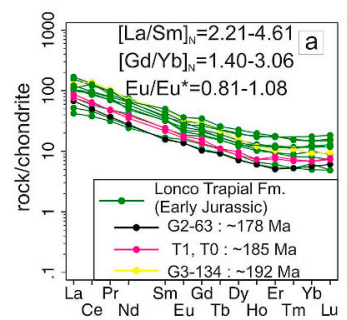

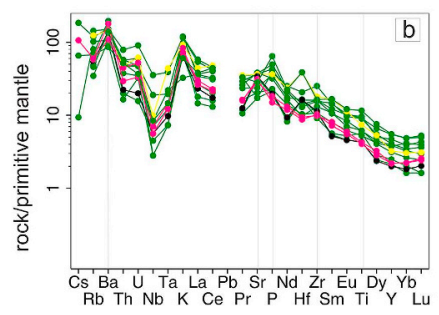

High-silica rocks $\left(\mathrm{SiO}_{2}>70 \%\right)$
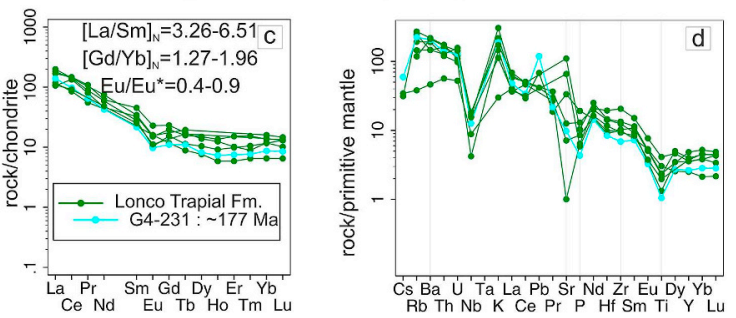

Eastern and central domains: Marifil Complex and Garamilla Fm. (sequences dominated by felsic rocks)
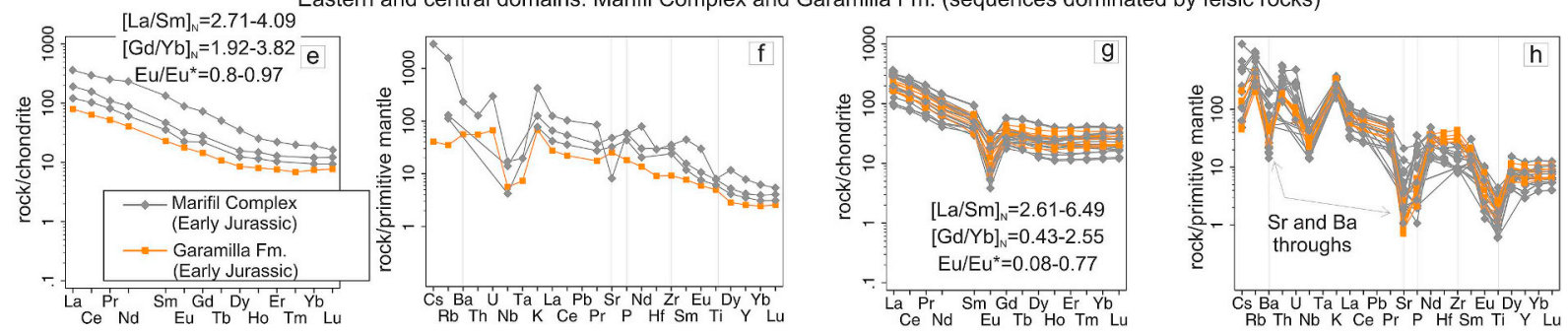

Western domain: Piltriquitrón and Lago La Plata formations and Subcordilleran Plutonic Belt
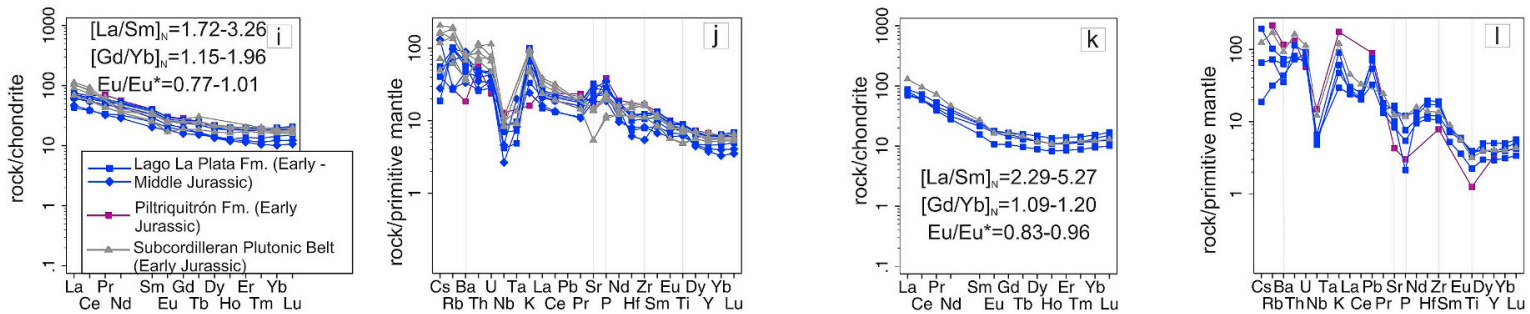

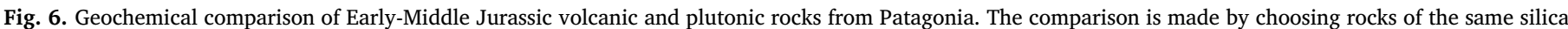

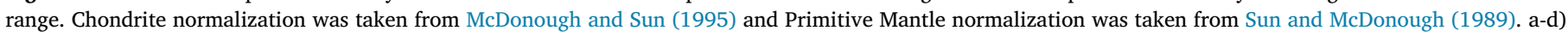

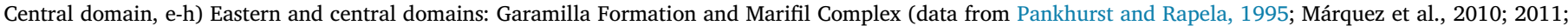

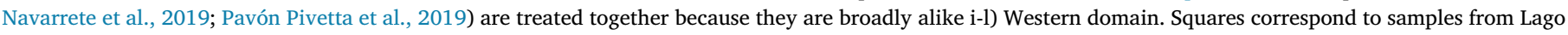

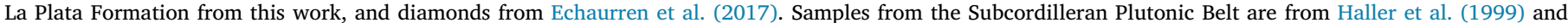
Rapela et al. (2005).

contrasts with the only small negative anomaly observed in Lonco Trapial rhyolites $\left([\mathrm{La} / \mathrm{Sm}]_{\mathrm{N}}=2.61-6.49 ;[\mathrm{Gd} / \mathrm{Yb}]_{\mathrm{N}}=0.43-2.55 ; \mathrm{Eu} /\right.$ $\mathrm{Eu}^{*}=0.08-0.77$; Fig. 6g). In addition, Garamilla Formation and Marifil Complex rhyolites have negative $\mathrm{Ba}, \mathrm{Sr}, \mathrm{P}$ and $\mathrm{Ti}$ anomalies (Fig. 6h).

The intermediate rocks from the western domain from Piltriquitrón, Lago La Plata formations and from the Subcordilleran Plutonic Belt also show a slight enrichment in light rare earth elements, flat heavy rare earth patterns and minor to no negative Eu anomalies ([La/ $\mathrm{Sm}]_{\mathrm{N}}=1.72-3.26 ;[\mathrm{Gd} / \mathrm{Yb}]_{\mathrm{N}}=1.15-1.96$ and $\mathrm{Eu} / \mathrm{Eu}^{*}=0.77-1.01$; Fig. 6i). They further show $\mathrm{Nb}$ and Ta depletion and $\mathrm{K}, \mathrm{Cs}, \mathrm{Rb}$ and $\mathrm{Ba}$ enrichment (Fig. 6j). The felsic rocks from the western domain are generally akin the rhyolites of Lonco Trapial Formation, as they show moderate enrichment in light rare earth elements, flat heavy rare earth element patterns and slight negative $\mathrm{Eu}$ anomalies ([La/ $\mathrm{Sm}]_{\mathrm{N}}=2.29-5.27 ;[\mathrm{Gd} / \mathrm{Yb}]_{\mathrm{N}}=1.09-1.20$ and $\mathrm{Eu} / \mathrm{Eu}{ }^{*}=0.83-0.96$; Fig. 6k). They also show slightly negative $\mathrm{Sr}$ and $\mathrm{Ba}$ anomalies and $\mathrm{Ti}$ and $\mathrm{P}$ troughs (Fig. 61).

\section{Isotopic data}

Five cleanly hand-picked amphibole samples from Lonco Trapial andesites from the Gastre area (Fig. 1) were analyzed for $\mathrm{Sr}$ and $\mathrm{Nd}$ isotope composition (Table 1). Initial ${ }^{87} \mathrm{Sr} /{ }^{86} \mathrm{Sr}$ ratios are within the range of 0.7056 and 0.7064 , and ${ }^{143} \mathrm{Nd} /{ }^{144} \mathrm{Nd}=0.512400-0.512568$ (Table 1; the ages for which the initial ${ }^{87} \mathrm{Sr} /{ }^{86} \mathrm{Sr}$ ratios were calculated are also specified there). $\mathrm{Rb}, \mathrm{Sr}, \mathrm{Sm}$ and $\mathrm{Nd}$ concentrations obtained by laser-ICP are used to calculate initial isotope compositions using the known age of the samples (Table 1). Initial epsilon $\mathrm{Nd}$ values are variable $(-0.68$ to -5.96 , Table 1$)$. These results presented here broadly agree with data presented by Pankhurst and Rapela (1995) and Dejonghe et al. (2002). The samples from Lonco Trapial Formation from Bouhier et al. (2017) are slightly more radiogenic in $\mathrm{Sr}\left({ }^{87} \mathrm{Sr} /{ }^{86} \mathrm{Sr}\right.$ ratios between 0.706695 and 0.711706 ) and have more negative initial epsilon Nd values (between -3.23 and -6.85, Bouhier et al., 2017).

The initial epsilon Nd values of Lonco Trapial Formation are negative. The trachyandesitic sample G3-134, which was dated at $\sim 192 \mathrm{Ma}$, is less radiogenic than the other andesitic samples, of $\sim 185$ and $\sim 178$ Ma (Fig. 7a).

The two-stage model Nd ages (based on the model of De Paolo et al., 1991) of around $1300 \mathrm{Ma}$ is interpreted as a maximum for mantle-separation of material with an average crustal $\mathrm{Sm} / \mathrm{Nd}$ ratio. These Mesoproterozoic, Grenvillian ages are typical crust formation ages within the North Patagonian massif (Pankhurst and Rapela, 1995; Martínez Dopico et al., 2011).

The isotopic compositions of $\mathrm{Sr}$ and $\mathrm{Nd}$ of other Early-Middle Jurassic units from the North Patagonian massif are plotted in Fig. 7a. The Jurassic intraplate magmas (Lonco Trapial Formation and Marifil Complex) are more crustal than the western Jurassic igneous rocks such as the North Patagonian Batholith (Pankhurst et al., 1999), the Subcordilleran Plutonic Belt (Rapela et al., 2005), the Lago La Plata Formation (Echaurren et al., 2017) and the Cañadón Huemules Formation 


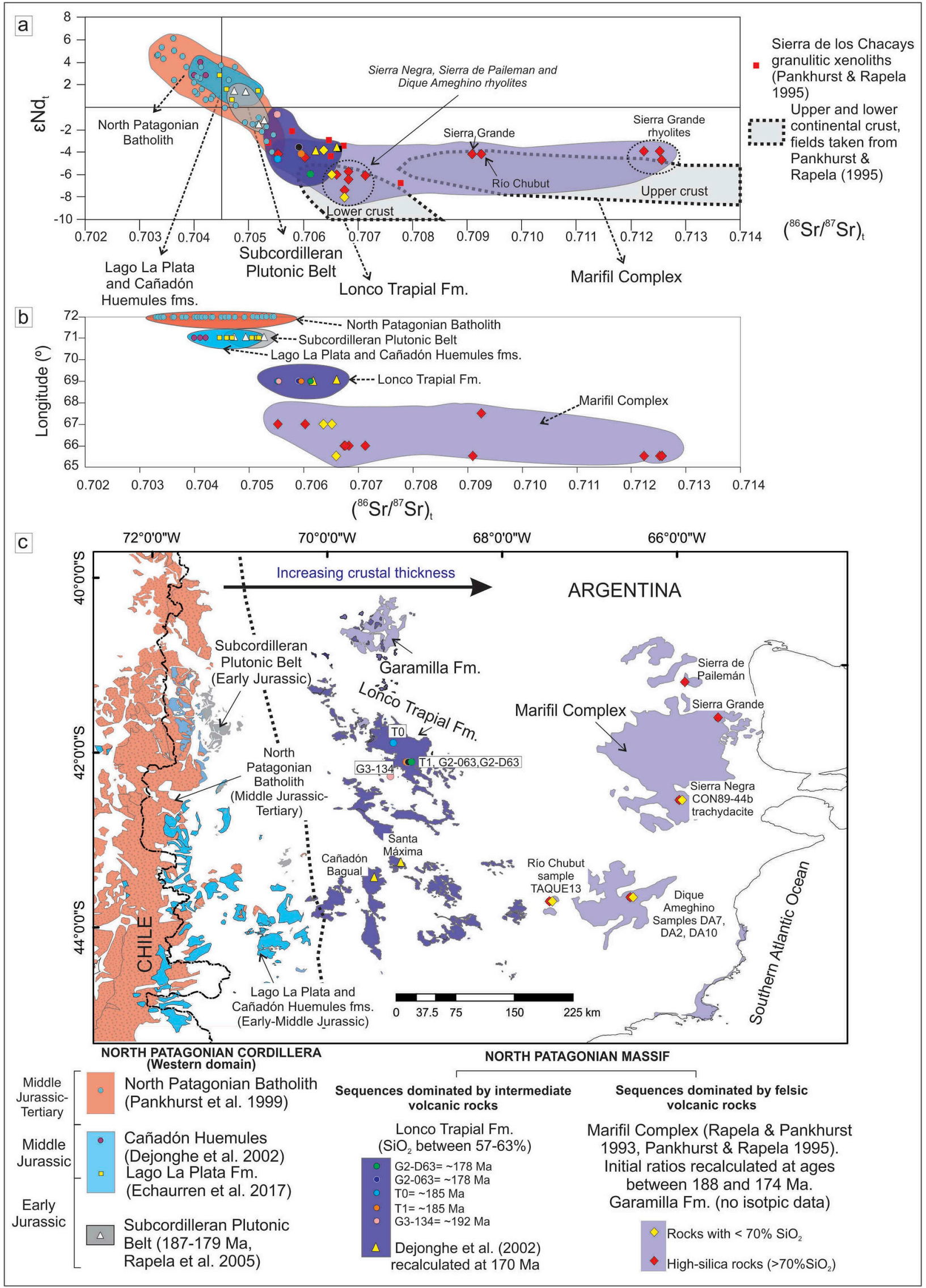

(caption on next page) 


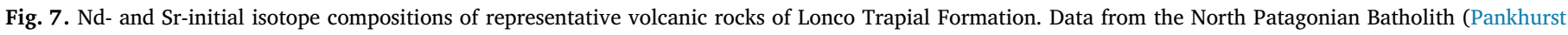

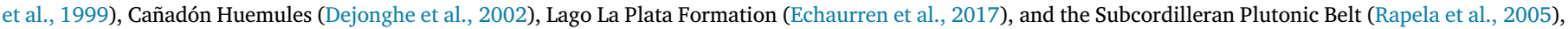

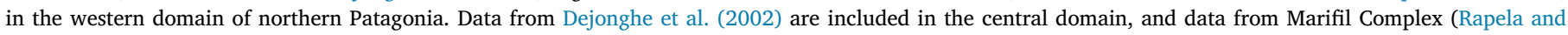

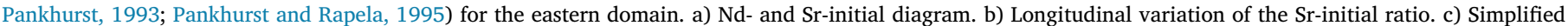

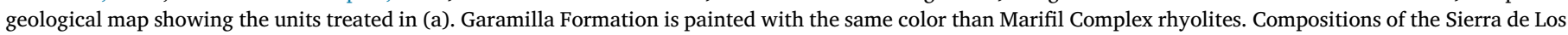

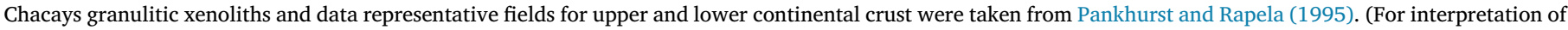
the references to color in this figure legend, the reader is referred to the Web version of this article.)

(Dejonghe et al., 2002). Within the Marifil Complex, the rhyolitic rocks show more evolved radiogenic isotopic signatures, whereas the rocks with lower silica content (basaltic sample DA7 from Dique Ameghino and andesitic sample TAQUE13 from the Rio Chubut area, Pankhurst and Rapela, 1995) have Sr isotopes more primitive, similar to the andesites of Lonco Trapial Formation presented here (Fig. 7a).

Fig. 7a, b and c also show that, when comparing the western and the central-eastern domains of northern Patagonia, the initial ${ }^{87} \mathrm{Sr} /{ }^{86} \mathrm{Sr}$ ratios increase from west to east while the initial epsilon $\mathrm{Nd}$ values become more negative.

\section{Petrogenetic and tectonic discussion}

\subsection{Magmatic evolution concerning andesites and rhyolites}

The synchronicity of the andesitic and rhyolitic volcanic events in the Early-Middle Jurassic magmatic suites from northern Patagonia is confirmed by the ages which were compiled in the introduction. The new age of $177.26 \pm 0.96$ Ma reported in Lagorio et al. (2018) and fully presented here for a rhyolitic dike ascribed to Lonco Trapial Formation also corroborates that andesites and rhyolites are coeval (rhyolite dike G4-231, Fig. 3).

As is well known in the literature, the origin of rhyolites is a controversial topic in petrology (Mahood and Halliday, 1988; Bachmann and Bergantz, 2008; Ayalew and Ishiwatari, 2011; Shellnutt et al., 2012; Lee et al., 2015; Lundstrom and Glazner, 2016; Aravena et al., 2017). While in some cases the felsic rocks are considered to be the result of lower crustal melting, with heat provided by mafic magma underplating, in other cases the felsic rocks are fractionation products from mafic mantle-derived magmas.

Considering major and trace elements, magmatic evolution involving fractionation of crystallizing minerals can be envisaged from $\mathrm{CaO}$, $\mathrm{Al}_{2} \mathrm{O}_{3}, \mathrm{MgO}$ and $\mathrm{FeO}_{(\mathrm{t})}$ which decrease with increasing silica contents (Fig. 4). Intermediate rocks from all suites have an evolution dominated by early fractionation of amphibole and clinopyroxene, titanomagnetite and minor plagioclase. The latter is attested by the lack of significant negative Eu, Sr and Ba anomalies (Fig. 6b, f, j; Fig. 8a) suggesting that feldspar fractionation was not a dominant process in the early evolution of the Jurassic magma suites. It should be considered that in water-rich andesitic melts, the liquidus of plagioclase is suppressed by $>100{ }^{\circ} \mathrm{C}$ (Sisson and Grove, 1993; Molina et al., 2009). On the other hand, fractionation of middle rare earth elements (Fig. 6a, e, i) and the negative trend in the $[\mathrm{Dy} / \mathrm{Yb}]_{\mathrm{N}}$ vs. silica (Fig. $8 \mathrm{~b}$ ) are compatible with amphibole and clinopyroxene fractionation while garnet did not fractionate nor remained as a residual phase in the source, according to Davidson et al. (2013).

Amphibole fractionation can also be inferred in the felsic rocks from all the studied unites, which is coherent with the depletion in middle rare earth elements (Fig. $6 \mathrm{c}, \mathrm{g}, \mathrm{k}$ ). With respect to plagioclase fractionation, two different behaviors can be outlined. On one hand, the rhyolites from the western domain (Lago La Plata and Piltriquitrón formations) lack negative $\mathrm{Eu}$ anomalies and $\mathrm{Sr}$ and $\mathrm{Ba}$ depletions (Fig. $6 \mathrm{~g}$ ). On the other hand, the rhyolites of the eastern domain (Marifil Complex and base of Marifil Complex, Fig. 6i) have marked negative Eu anomalies (Fig. 8a) together with the negative spikes in $\mathrm{Sr}$ and Ba consistent with feldspar crystallization. REE patterns of the rhyolites from the western domain are similar to the cold-wet-oxidized rhyolites typical of subduction zones, whereas the REE patterns of the rhyolites of the eastern domain resemble the hot-dry-reduced rhyolites, which are fueled by decompression melting of the mantle in intraplate settings (Christiansen, 2005; Christiansen and McCurry, 2008; Bachmann and Bergantz, 2008). In the central domain, Lonco Trapial rhyolites resemble the cold-wet-oxidized types of the western domain, whereas the rhyolites of the Garamilla Formation are more akin to the hot-dry-reduced rhyolites like those of the eastern domain (Fig. 6h; Fig. 8a).

Apatite fractionation can be inferred from $\mathrm{P}_{2} \mathrm{O}_{5}$ which decreases (Fig. $4 \mathrm{~h}, \mathrm{j}$ ) only in the most felsic rocks and shows a strong negative anomaly in normalized trace element patterns (Fig. 6 b, f, j, d, h, l).

\subsection{Mass balance constraints and petrological modeling}

Mass balance estimations based on major elements were performed in order to investigate the evolution of intermediate to felsic volcanic rocks within Lonco Trapial magmas. First, the andesite G2-63 was considered as the starting material, and the trachydacite G2-69 was regarded as the final composition (Table 1-Appendix d). The results of the mass balance model returned plagioclase $(10 \%)$, clinopyroxene (5\%), hornblende $(10 \%)$ and biotite $(1 \%)$ as fractionated minerals, with $26 \%$ of residual melt and the sum of the squares of the residuals was 1.6 (Table 2). These percentages of the fractionating minerals roughly correlate with the observed phenocryst assemblage in the andesite G263, but $\Sigma \mathrm{res}^{2}>1$ does not support fractional crystallization from mass balance calculations. On the other hand, calculations starting from trachydacites (sample G2-69) to obtain rhyolites (sample G4-185, Table 1-Appendix d), were not successful at all as the sum of squares of residuals was very high ( $\Sigma \mathrm{res}^{2}$ up to 8.6 ) when plagioclase, amphibole and biotite were considered as the fractionating mineral phases (Table 2).

In order to test the possibility of rhyolite genesis from andesitic magmas by crystal fractionation, crustal assimilation or mixing, we employed the software by Ersoy and Helvaci (2010) that models fractional crystallization (FC), fractional crystallization combined with assimilation (AFC), and decoupled fractional crystallization and assimilation (FCA). Again, the starting sample is the andesite G2-63, and the assimilant composition was the upper continental crust (Taylor and McLennan, 1995). The composition of the lower crust (Taylor and McLennan, 1995) is included in the diagram as well, but it overlaps with the andesitic samples of Lonco Trapial (Fig. 9). Intermediate melt compositions partition coefficients were chosen (Ersoy and Helvaci, 2010 and references therein). Model results for La and Th are shown in Fig. 9 and better describe the evolution from andesites to rhyolites in Lonco Trapial Formation by fractional crystallization decoupled from crustal assimilation (FCA). La concentrations are significantly higher in magmas that evolve by this process than in those that evolve by combined fractional crystallization and crustal assimilation (AFC; De Paolo, 1981, Fig. 9). In decoupled assimilation and fractional crystallization processes, the rate of assimilation need not be strictly dependent upon the rate of crystallization. This allows for additional heat input that leads to raise the temperature and melt the wall rocks by advection involving hot, primitive magma which pond beneath the evolved magma chamber without compositional interaction. This provides sufficient heat for magmas to assimilate crustal material without undergoing crystallization. In this scenario, assimilation processes are similar 

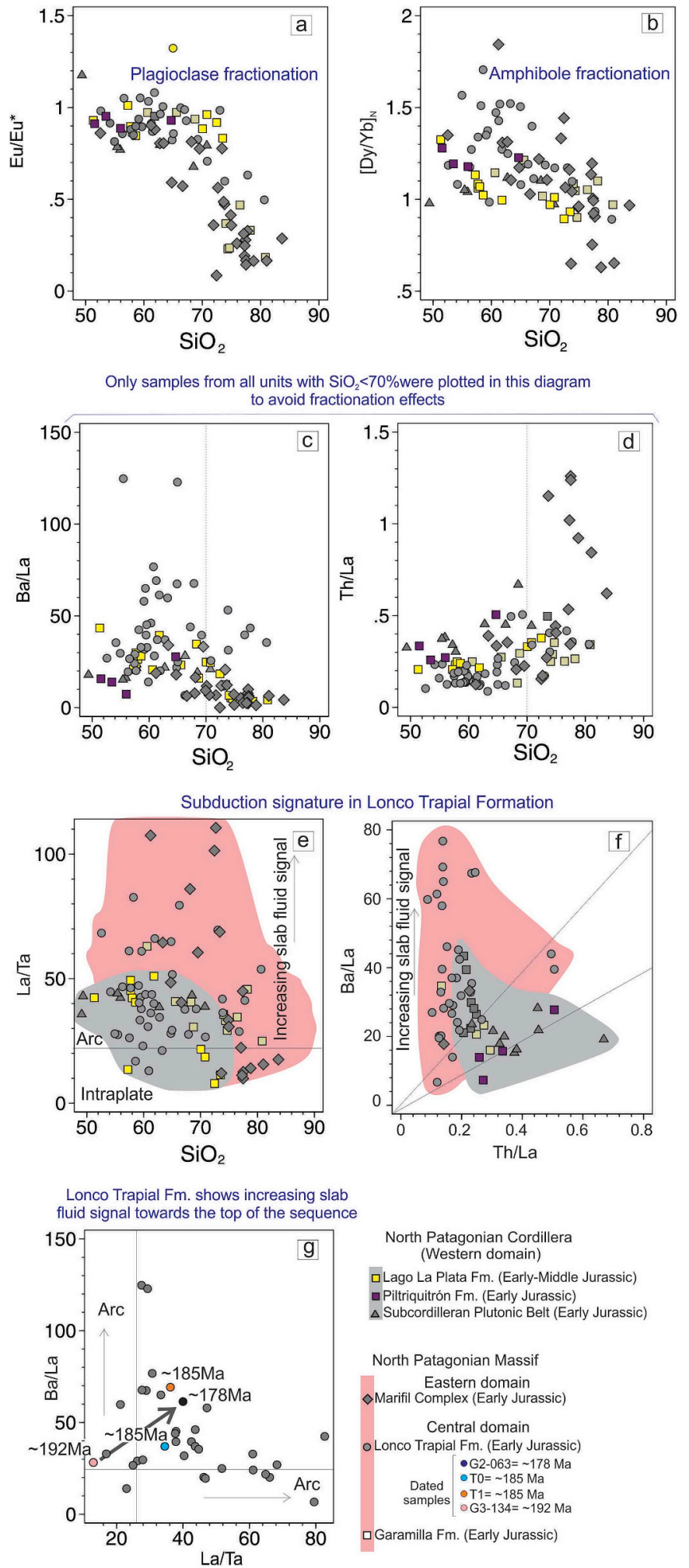

Fig. 8. Selected trace element ratios for Early-Middle Jurassic igneous rocks. a) Descending trend of $\mathrm{Eu} / \mathrm{Eu}^{*}$ vs. $\mathrm{SiO}_{2}$ suggesting plagioclase fractionation. b) $[\mathrm{Dy} / \mathrm{Yb}]_{\mathrm{N}}$ vs. $\mathrm{SiO}_{2}$ diagram. The negative trend with increasing silica suggests amphibole fractionation c-e) $\mathrm{Ba} / \mathrm{La}, \mathrm{Th} / \mathrm{La}$ and $\mathrm{La} / \mathrm{Ta}$ vs. silica diagrams. f) $\mathrm{Ba} /$ La vs. La/Ta diagram. g) Ba/La vs. La/Ta diagram. Data from Lago La Plata Formation (Echaurren et al., 2017), Marifil Complex (Pankhurst and Rapela, 1995; Márquez et al., 2011; Navarrete et al., 2019; Pavón Pivetta et al., 2019), Subcordilleran Plutonic Belt (Haller et al., 1999; Rapela et al., 2005) and Lonco Trapial Formation (Dejonghe et al., 2002) are included for comparison. Lines defining arc field ratios according to Kay et al. (2006).

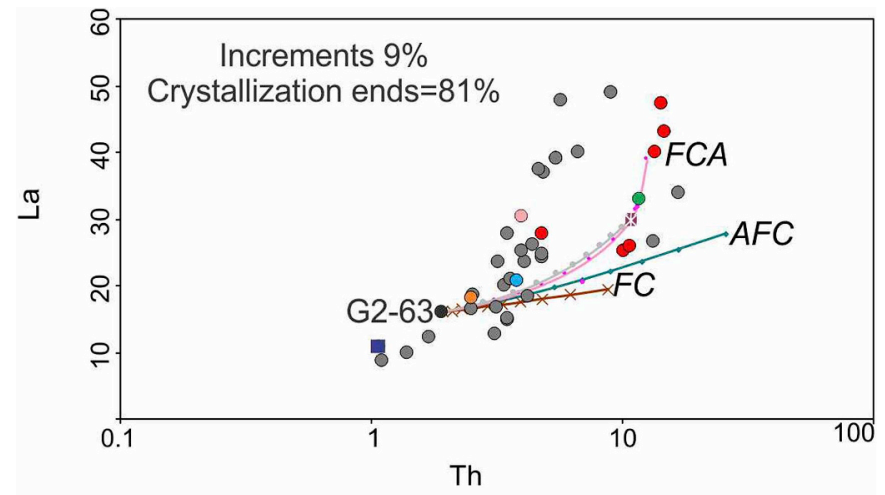

$$
\begin{aligned}
& \text { Lonco Trapial Fm. } \\
& \text { - Rocks with }<70 \% \mathrm{SiO}_{2} \\
& \text { - High-silica rocks }\left(>70 \% \mathrm{SiO}_{2}\right) \\
& \text { * Upper continental crust } \\
& \text { (Taylor \& McLennan 1995) } \\
& \text { Lower continental crust } \\
& \text { (La=30; Th=10.7) } \\
& \text { (Taylor \& McLennan 1995) }
\end{aligned}
$$$$
\text { Dated }\left[\begin{array}{l}
\bullet \mathrm{G} 4-231=\sim 177 \mathrm{Ma} \\
\bullet \mathrm{G} 2-063=\sim 178 \mathrm{Ma}
\end{array}\right.
$$$$
\text { samples } \bigcirc \mathrm{T} 0=\sim 185 \mathrm{Ma}
$$$$
\text { - } \mathrm{T} 1=\sim 185 \mathrm{Ma}
$$$$
\text { o G3-134= 192 Ma }
$$

Fig. 9. Origin of the rhyolites in Lonco Trapial Formation. Geochemical model made with the Excel spreadsheet of Ersoy and Helvaci (2010). We have approximated the composition of the parental magma by using the most primitive sample (amphibole-andesite G2-63). As contaminants we have used the upper continental crust of Taylor and McLennan (1995). The figure shows that to produce the rhyolites of Lonco Trapial and Garamilla, a curve of FCA (decoupled fractional crystallization and assimilation) is needed, and not only coupled fractional crystallization and assimilation (AFC) or fractional crystallization (FC) alone.

to simple bulk mixing (Cribb and Barton, 1996). Decoupled assimilation and fractional crystallization are likely to be important in MASH zones, located near the base of the crust, where ambient temperatures are relatively high, and the heat released by crystallization of multiple batches of mafic magma should cause crustal anatexis (Hildreth and Moorbath, 1988). In conclusion, a process of crustal assimilation decoupled from fractional crystallization, with amphibole, clinopyroxene, minor plagioclase (as no significative Eu and $\mathrm{Sr}$ anomalies were found in the intermediate rocks of this series, Figs. $6 \mathrm{~b}$ and $8 \mathrm{c}$ ) and biotite as the main fractionating phases within a MASH zone, can be envisaged as reasonable for producing the more silicic magmas of Lonco Trapial Formation. The presence of plagioclases with sieve texture and with evidence of corrosion (corroded and uncorroded crystals in the same sample) in andesites of Lonco Trapial Formation may be interpreted as petrographic evidence of the crustal assimilation process as well. Furthermore, the crustal isotopic signature of Lonco Trapial magmas (Fig. 7) reinforces the contribution of crustal assimilation.

\subsection{Isotopic composition and assessment of the role of crustal contamination}

The Lonco Trapial Formation rocks extend the isotope trends indicated by the Subcordilleran Batholiths and the Lago La Plata Formation, that are characterized by an increase in Sr isotope correlated to a decrease in $\mathrm{Nd}$ isotopes. It should be noted that andesitic samples of Lonco Trapial plot near the field of lower crust compositions (Fig. 7)

The obtained $T_{\mathrm{DM}}$ that span from 1.056 to $1.458 \mathrm{Ga}$ (average $1.3 \mathrm{Ga}$, Table 1) suggest reworking of continental crust of Mesoproterozoic age in the origin of the magmas of this central volcanic belt of northern Patagonia, as was previously pointed out by Pankhurst and Rapela (1995) for the Chon Aike Volcanic Province. Lower crustal pyroxene- 
granulite xenoliths enclosed in some Tertiary alkalic intrusions from Los Chacays were considered as residual source after magma extraction by the latter authors. $\mathrm{Nd}$ and $\mathrm{Sr}$ isotope compositions of the granulites $($ Sri $=0.7065-07078 ; \epsilon \mathrm{Ndt}=-3.0$ to -6.8 ; TDM $=1270-1537 \mathrm{Ma})$ overlap with many high-silica rocks of the Marifil complex $($ Sri $=0.7067 \pm 0.0005 ; \quad \epsilon \mathrm{Ndt}=-3.9$ to -8.2 ; $\mathrm{TDM}=1323-1556 \mathrm{Ma}$ ) and some andesites and rhyolites of the central domain. More recently, Castro et al. (2011b) presented data from granulite nodules from Tertiary alkali basalts in Paso de Indios locality. Their geochemical data, an U-Pb zircon age (176 $\pm 5 \mathrm{Ma})$ and a proposed decompression path from pressure of $0.9 \mathrm{GPa}$ at temperatures of about $1000{ }^{\circ} \mathrm{C}$ suggests that the lower crust of northern Patagonia underwent a high temperature melting event in Early Jurassic times. In both cases, these xenoliths that are considered representative of the lower crust, are strongly depleted in incompatible elements which is attributed to a residual origin of the granulites.

Pankhurst and Rapela (1995) inferred an andesite composition for the magma in equilibrium with the granulites. More silicic rocks could then be produced by partial re-melts of andesite magmas that had crystallized in the lower crust, with later stages of evolution by fractional crystallization of plagioclase, amphibole and accessory minerals. However, Castro et al. (2011b) suggested, based on the average composition of restites in experiments, that their partial melts can be of granitic to granodioritic composition. In any case, all these arguments indicate that a Mesoproterozoic lower crust must be considered as an important alternative source for Early-Middle Jurassic magmas in the eastern and central sectors of northern Patagonia.

In addition, contamination with the upper crustal metasediments could have produced higher $\mathrm{Sr}$ ratios as well, for example those observed in highly evolved Sierra Grande rhyolites. Anyway, the range of $\mathrm{Pb}$ isotope values for Lonco Trapial rocks presented by Dejonghe et al. (2002) indicate the contribution of both, mantle and crust, with a particular role of a lower crustal component. Thus, according to these authors, the lead isotope compositions across the entire region indicate a crustal contribution to mantle derived magmas that increased from west to east. Anyway, high $\mathrm{Pb}$ concentrations ranging from 4.8 to $36 \mathrm{ppm}$ in samples from Cañadón Asfalto and Lonco Trapial Formations, suggest assimilation with the upper crust (Bouhier et al., 2017).

Furthermore, based on $\mathrm{Pb}$ isotopic values, samples of Lonco Trapial Formation as well as basic to intermediate volcanic rocks of the Cañadón Asfalto Formation fall near the orogeny curve of Zartman and Doe (1981) and thus suggest mixing between two reservoirs of $\mathrm{Pb}$, with contributions of mantle and crust (Bouhier et al., 2017).

Isotopic data show that, when going from the western to the central and eastern domains of northern Patagonia, there is a gradient of increasing radiogenic Sr content which is ascribed to increasing crustal contribution to the Early-Middle Jurassic magmas (Fig. 7b-c; see also Bruce et al., 1991; Rapela et al., 2005). We performed some diagrams to test if there was a west-east variation of crustal thickness along the western and central-eastern domains of northern Patagonia. These diagrams were designed for calc-alkaline, arc-derived magmas (Profeta et al., 2015), but they are used here as broad estimations of the depth to the source, because the intermediate rocks $\left(55-68 \mathrm{SiO}_{2} \mathrm{wt} \%\right.$ ) of all the suites analyzed here have unmistakable calc-alkaline features (see the previous section). To construct the diagrams, samples with less than $4 \mathrm{wt} \% \mathrm{MgO}$ were left out, as well as samples with $\mathrm{Rb} / \mathrm{Sr}>0.2$ and $\mathrm{Rb} /$ $\mathrm{Sr}<0.05$ (Profeta et al., 2015). After this filtering, the $[\mathrm{Sm} / \mathrm{Yb}]_{\mathrm{N}}$ and $\mathrm{Sr} / \mathrm{Y}$ ratios of the intermediate rocks from the western magmatic series from northern Patagonia (Lago La Plata, Piltriquitrón and the Subcordilleran Plutonic Belt) are lower than the ones from the central and eastern magmatic series (Lonco Trapial, Marifil, Garamilla, Fig. 10a-b).

Fig. 10a indicates that $[\mathrm{Sm} / \mathrm{Yb}]_{\mathrm{N}}$, which is normally ascribed to increasing depth of the magma processing within the crust is greater for rocks from the eastern and central regions than for rocks of the western region. In addition, geothermobarometric determinations performed on amphiboles and plagioclases from andesitic rocks from Lonco Trapial
Formation show that they crystallized at a maximum depth of $\sim 28 \mathrm{~km}$, which can be considered as the maximum crustal thickness in the Gastre region in Early Jurassic times (Zaffarana et al., 2018). Probably, the greater crustal thickness in the eastern domain could have increased the role of crustal contamination.

\subsection{Geochemical signature of the Early-Middle Jurassic rocks and tectonic setting}

Intermediate magmas from Lonco Trapial, Garamilla, Lago La Plata and Piltriquitrón formations have relatively low $\mathrm{Cr}$ and $\mathrm{Ni}$ and thus do not represent primitive magmas (Table 1-Appendix a-e). Ba/La (Fig. $8 \mathrm{c}$ ), $\mathrm{Ba} / \mathrm{Nb}$ and $\mathrm{Th} / \mathrm{U}$ ratios of the analyzed suites are rather constant with increasing silica, whereas $\mathrm{Nb} / \mathrm{Yb}$ and $\mathrm{Th} / \mathrm{La}$ tend to increase with silica, especially at $\mathrm{SiO}_{2}>70 \%$ (Fig. $8 \mathrm{~d}$ for Th/La vs. silica, the other ratios are not shown). In order to attempt to better constrain the composition of the source of these contaminated magmas, the effect of fractionation and assimilations needs to be reduced. Therefore, only the rocks with $\mathrm{SiO}_{2}<70 \%$ were considered to evaluate source characteristics.

Rocks from the Lonco Trapial and Garamilla formations and Marifil Complex have high $\mathrm{La} / \mathrm{Ta}$ ratios (Fig. $8 \mathrm{e}, \mathrm{La} / \mathrm{Ta}$ vs. $\mathrm{SiO}_{2}$ ) which locate them in the arc field ( $\mathrm{La} / \mathrm{Ta}$ ratios up to $\sim 83$, Table 1-Appendix). However, the compositions of these units show great scatter, with some of them having rather low $\mathrm{La} / \mathrm{Ta}$ ratios $(\mathrm{La} / \mathrm{Ta}$ ratios as low as 13 , Table 1-Appendix) more compatible with intraplate magmas. The high to moderate $\mathrm{La}$ /Ta ratios from Lago La Plata Formation are transitional within arc and intraplate magmas fields (La/Ta between 8 and 42). In contrast, the $\mathrm{La} / \mathrm{Ta}$ ratios greater than 25 from the Subcordilleran Plutonic Belt (La/Ta ratios are between 38 and 44), fall well within the field of arc-related rocks (Fig. 8e).

As both Lonco Trapial and Garamilla show large $\mathrm{Ba} / \mathrm{La}$ variations, the high $\mathrm{Ba} / \mathrm{La}$ values that can be reached (up to almost 80 ) are clearly reflecting the influence of the fluids coming from the subducting slab (Fig. 8f). In summary, the subduction affinity of Lonco Trapial is evidenced in the high La/Ta and $\mathrm{Ba} / \mathrm{La}$ ratios (diagrams of Fig. 8e-f).

The arc signature of Lonco Trapial magmas is also indicated by their depletion in $\mathrm{Nb}$ and $\mathrm{Ta}$ as well as $\mathrm{Pb}$ positive anomalies (Fig. 6e). Nevertheless, these geochemical features can also be caused by large degrees of crustal contamination.

In addition, the arc signature of Lonco Trapial magmas increased towards the top of the sequence, as ratios increase with decreasing age (Fig. 8g). The initial magmas of this unit are enriched in incompatible elements suggestive of intraplate affinities (represented by G3-134, $\sim 192 \mathrm{Ma}$ ) whereas later magmas clearly show a calc-alkaline geochemical signature (e.g. G2-73, 178 Ma).

It should be noted that even though some geochemical indicators suggest decreasing subduction characteristics of the Early-Middle Jurassic magmatic series towards the east (Fig. 5), others show opposite trend (Fig. 8e-f).

The products of the western magmatic domain in northern Patagonia are thought to have originated in response to easterly subduction of oceanic crust along the western Gondwana margin (i.e. Baker et al., 1981; Gust et al., 1985; Pankhurst et al., 1998, Echaurren et al., 2017) as represented by the Subcordilleran Plutonic Belt and associated units (Fig. 7).

Instead, the Garamilla Formation and the Marifil Complex from the central and eastern domain respectively, formed farther away from this paleo-subduction zone and in a more cratonic environment towards the east and north. These also show a higher proportion of felsic rocks in this intraplate position. In addition, the rhyolites of these units are hotdry-reduced, typical of intraplate tectonic settings. As previously mentioned, rhyolites predominate in these units, and they are associated with minor basaltic andesites and andesites, and, more rarely, with basalts (Malvicini and Llambías, 1972; Pankhurst and Rapela, 1995; Pankhurst et al., 1998). As pointed out by Pankhurst and Rapela 


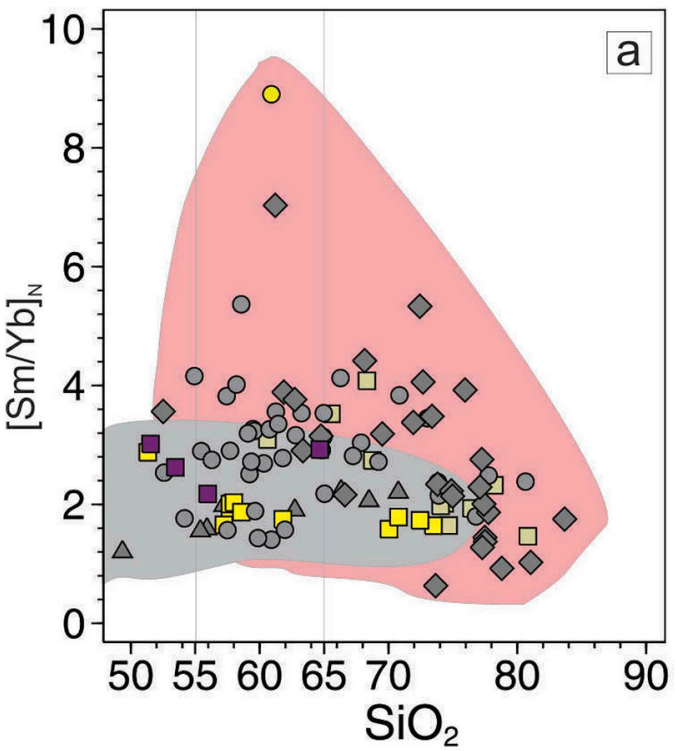

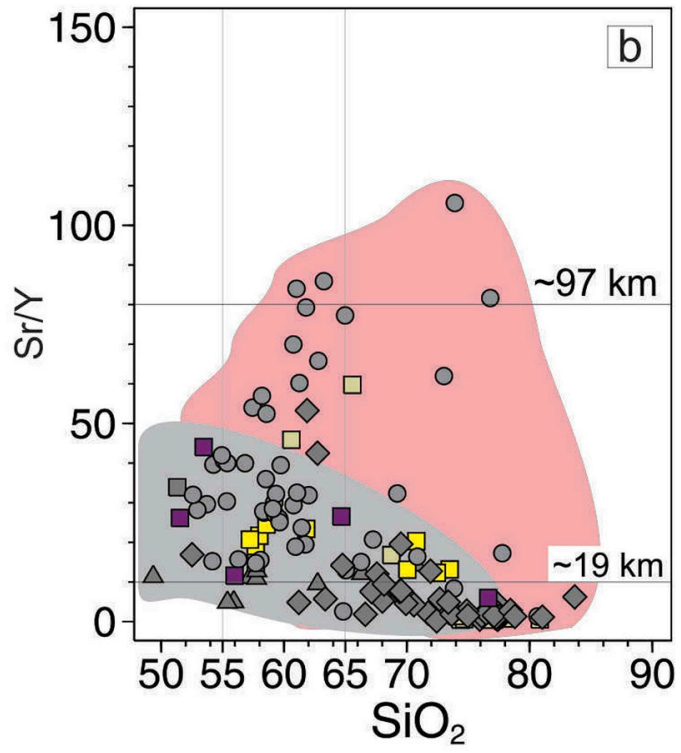

North Patagonian Massif

Eastern domain

$\diamond$ Marifil Complex (Early Jurassic)

Central domain

o Lonco Trapial Fm. (Early Jurassic)

$\square$ Garamilla Fm. (Early Jurassic)

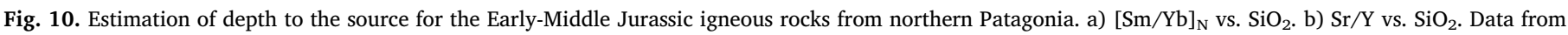
other units as in Fig. 8.

(1995) these felsic magmas, particularly those located in the eastern domain as represented by rhyolitic rocks of the Marifil Complex are mainly the product of the anatexis of lower crust.

The limit between the western and central domains of northern Patagonia coincides, in fact, with the limit between two morphostructural units, the North Patagonian Massif and the North Patagonian Cordillera (Fig. 7; i.e. Oriolo et al., 2019). The thicker crust presented by the North Patagonian Massif (comprising the central and eastern domains of northern Patagonia, Fig. 10a-b) would have been inherited from the Gondwanide Orogeny, which affected the Pacific subduction margin of Pangea (Keidel, 1921; Cawood, 2005; Cawood and Buchan, 2007).

The subduction signature of the rocks of Lonco Trapial from the central Patagonia domain could be ascribed to their rear-arc position with respect to the ongoing subduction in the western Gondwana margin. Instead, decompression melting of mantle enriched by previous subduction events rather than by contemporaneous subduction can be considered (Hooper et al., 1995) in order to explain calc-alkaline magmatism associated with lithospheric extension. Furthermore, crustal contamination may have played a role as well. Previous subduction events can be attributed to Gondwanide Orogeny in Late Permian times (Keidel, 1921; Cawood, 2005; Cawood and Buchan, 2007). Anyway, it should be noted that previous orogenic processes occurred along the western edge of Gondwana (i.e. Varela et al., 2005; Pankhurst et al., 2006; Vizán et al., 2017) between the Devonian and the Late Carboniferous. This active continental margin would have a been located approximately along the present Chubut River, which represents the southern limit of the North Patagonian Massif, as observed in the reconstruction of Gondwana (Fig. 7 of Renda et al., 2019). This margin has a NW-SE direction where also the outcrops of Lonco Trapial rocks are located. Subduction processes at that margin up to Late Carboniferous times may have enriched the underlying mantle by subduction-related fluids.

Partial melting of this metasomatized mantle and lower crust, involving mixed source according to $\mathrm{Pb}$ isotope data (i.e. Dejonghe et al., 2002; Bouhier et al., 2017), formed magmas that were subsequently modified at shallow crustal levels by low-pressure differentiation and assimilation to produce Lonco Trapial andesitic to rhyolitic magmas. Further isotopic data would be needed to better constrain and quantify the source contributions and evolution of the felsic members of this suite. Future studies especially focused on Hf isotopes of felsic rocks of the Lonco Trapial and Garamilla formations should help to better define their origin. In particular, we need to better constrain whether these magmas were generated purely by lower crustal anatexis (as the rocks of the Marifil Complex) or rather represent products of dominantly magmatic differentiation at shallow upper crustal levels. A study of this kind would also allow to elucidate the genesis of the felsic terms of the Early Jurassic bimodal volcanism in northern Cordillera del Viento (e.g. Zappettini et al., 2018).

Another important related issue is the heat source needed to produce large volumes of lower crustal melt to generate rhyolite magmas of the Marifil Complex. Assimilation and melting of the crust requires significant and persistent heat input by intrusions of large volumes of mantle-derived magmas into the lower crust (Annen and Sparks, 2002; Annen, 2009; Whittington et al., 2009; Furlong and Chapman, 2013). Pankhurst and Rapela (1995) considered that extension associated with Gondwana break-up could explain the important anatexis process. Riley et al. (2001) and Pankhurst and Rapela (1995) proposed that lower crustal melting in Patagonia and on the Antarctic Peninsula could have been caused by heating and underplating of basaltic magma related to a mantle plume that was also responsible for the Karroo and Ferrar flood basalts (Discovery-Shona-Bouvet group; Storey et al., 2001). Migration over a mantle plume was also invoked to explain the age progression of magmatism in the Chon Aike Volcanic Province (Riley and Leat, 1999; Pankhurst et al., 2000; Riley et al., 2001; Navarrete et al., 2019).

A mafic underplating below the eastern domain of northern Patagonia is supported by the geophysical modeling of Introcaso (2003) 
in the Colorado basin, Argentina, which is elongated in a direction perpendicular to the present Atlantic coast. The Colorado basin was related by Introcaso and Ramos (1984) to the opening of the Southern Atlantic Ocean. This basin shows a positive gravimetric anomaly compatible with an isostatic overcompensation caused by the lower crustal intrusion of hot asthenospheric material (Introcaso, 2003). Pedraza de Marchi et al. (2017) also showed that the Argentinian passive margin (Hinz et al., 1999) a positive gravimetric anomaly caused by mafic underplating in the present marine platform, originated during the Gondwana breakup stage.

\section{Conclusions}

The following conclusions can be reached by considering all the Early-Middle Jurassic magmatic units from northern Patagonia:

-The units under analysis were separated in three domains: western, central and eastern. The rocks of the central domain constituted the main part of this study. New data are presented, also, from rocks of the western domain (Piltriquitrón and Lago La Plata formations).

-Within the central domain, the rocks can be broadly classified as andesites and rhyolites. The stratigraphic relationship between them is variable: the rhyolites can be either above or below the andesites. At the north, in the area between Ingeniero Jacobacci and Piedra del Águila, the rhyolites are more abundant than in the southern area around Gastre (Fig. 1). In the northern part of the area of study, the rhyolites are generally comprised within Garamilla Formation, whereas in the southern part both andesites and rhyolites are gathered under the name of Lonco Trapial Formation. In general terms, the petrographic association of the central domain of northern Patagonia is formed by andesites, dacites and rhyolites.

-A new U-Pb age of $177.26 \pm 0.96 \mathrm{Ma}$ is presented for a rhyolite dike of Lonco Trapial Formation that belongs to the Los Manantiales district, near Gastre.

-Lonco Trapial lavas are metaluminous to peraluminous and belong to the calc-alkaline series indicative of a volcanic arc setting. However, some samples show trace elements ratios and mineral compositions with a slight alkaline affinity, characteristic of intraplate magmas.

-A significant thermal and melting event affected the lower crust during the Early Jurassic times. Depleted-mantle model ages agree with previous results and reinforce the important role of Mesoproterozoic lower crust as a source of the Early Middle Jurassic magmas in the eastern and central sectors of northern Patagonia.

- The heat source was likely associated with widespread basaltic underplating related to mantle melting during the initial break-up of Gondwana. Such a heat source is confirmed by published geophysical data.

-Felsic rocks from the eastern domain (Marifil Complex) mainly reflect anatexis of the lower crust, as was pointed out by previous authors. In the central domain, for the andesitic rocks of Lonco Trapial Formation, melting must have involved mantle and lower crustal sources as supported by $\mathrm{Pb}$ isotopic data provided by other authors.
Ascent to shallow crustal levels with subsequent low-pressure differentiation and assimilation can explain the geochemical features of Lonco Trapial magmas from andesites to highly evolved rhyolites.

- The rhyolites of Marifil Complex and of Garamilla Formation are hot-dry-reduced, typical of intraplate environments, whereas the rhyolites of Lonco Trapial Formation are cold-wet-oxydized, more akin the rhyolites from the western magma series (Piltriquitrón and Lago La Plata formations and the Subcordilleran Plutonic Belt), which are typical of subduction environments. Isotopic data are needed to better constrain the genesis of felsic magmatism from the central domain in order to elucidate if they were formed by anatexis of the lower crust such as the rocks of the Marifil Complex or reflect differentiation processes.

- By contrast, the geochemical and isotopic trends shown by rocks from the western domain clearly contain an asthenospheric mantle component followed by contamination of magmas with the upper crustal rocks.

- The arc signature of magmatic rocks of the western domain reflects the subduction during Early Jurassic times and relates to the Subcordilleran Plutonic Belt. The arc signature of Lonco Trapial magmas from the central domain, located far from the volcanic arc, is considered to result from decompression melting of mantle that was enriched by previous subduction events (i.e. Devonian to Late Carboniferous times) rather than by contemporaneous Early Jurassic subduction. In addition, crustal contamination may have played a role as well, in particular where crustal thicknesses increase eastwards.

- Overall, variable mantle and crustal components and different settings with respect to the active margin can explain the mixed characteristics of slab-derived and intraplate magmas that characterize the Early-Middle Jurassic igneous sequences from northern Patagonia.

\section{Declaration of competing interest}

The author(s) declare(s) that there is no conflict of interest.

\section{Acknowledgements}

This work was financed with PIP CONICET 112-200901-00766, PICT 2014-1394 and with the Torandes Project (CGL 2012-38396-C03) from the Plan de I + D + i Español with UE-FEDER funds and the projects PI40A-547 and PI-40A-631 from the Universidad Nacional de Río Negro. Special thanks are given to Maria Helena Hollanda for helping with the geochemical analysis of some samples at Acmelabs. Thanks are given to Dr. Alberto Saal for his valuable comments which helped to improve this manuscript. We would like to thank the landowners who kindly permitted us to study the rocks of their field. Special thanks are given to Carlos Rapela and to Gabriela Massaferro for their valuable suggestions which greatly helped to improve this manuscript. We want to dedicate this work to the memory of our mentor and friend Rubén Somoza.

\section{Appendix}

Whole-rock geochemical data presented on anhydrous basis. Laboratory code is:

\begin{tabular}{|c|c|c|c|c|c|c|c|c|c|c|c|}
\hline Sample name & 1 & 2 & TAQUE1 & TAQUE2 & TAQUE3 & TAQUE5 & TAQUE6 & TAQUE7 & TAQUE8 & GARA1 & GARA3 \\
\hline Latitude & -41.21 & -41.21 & -41.30 & -41.30 & -41.30 & -41.28 & -41.28 & -41.27 & -41.28 & -41.23 & -41.29 \\
\hline Longitude & -69.35 & -69.35 & -70.18 & -70.18 & -70.18 & -70.18 & -70.17 & -70.15 & -70.11 & -69.42 & -70.07 \\
\hline \multirow[t]{2}{*}{ Locality } & Ingeniero & Ingeniero & Ingeniero & Ingeniero & Ingeniero & Ingeniero & Ingeniero & Ingeniero & Ingeniero & Ingeniero & Ingeniero \\
\hline & Jacobacci & Jacobacci & Jacobacci & Jacobacci & Jacobacci & Jacobacci & Jacobacci & Jacobacci & Jacobacci & Jacobacci & Jacobacci \\
\hline Unit & $\mathrm{G}$ & G & G & $\mathrm{G}$ & G & $\mathrm{G}$ & G & G & $\mathrm{G}$ & G & G \\
\hline Age & - & - & - & - & - & - & - & - & - & - & - \\
\hline $\begin{array}{l}\text { Geochemical clas- } \\
\text { sification }\end{array}$ & Dacite & Dacite & Andesite & Rhyolite & Dacite & Dacite & Rhyolite & Rhyolite & Rhyolite & Rhyolite & Rhyolite \\
\hline Laboratory & 1 & 1 & 2 & 2 & 2 & 2 & 2 & 2 & 2 & 2 & 2 \\
\hline
\end{tabular}




\begin{tabular}{|c|c|c|c|c|c|c|c|c|c|c|c|}
\hline $\mathrm{SiO}_{2}$ & 68.33 & 64.23 & 60.60 & 74.05 & 65.57 & 68.74 & 76.45 & 74.37 & 80.82 & 78.23 & 74.67 \\
\hline $\mathrm{TiO}_{2}$ & 0.68 & 0.64 & 0.64 & 0.35 & 0.52 & 0.41 & 0.31 & 0.22 & 0.16 & 0.20 & 0.22 \\
\hline $\mathrm{Al}_{2} \mathrm{O}_{3}$ & 14.01 & 14.07 & 16.74 & 12.62 & 16.70 & 16.71 & 12.78 & 13.68 & 9.50 & 11.11 & 13.47 \\
\hline $\mathrm{FeO}$ & 5.74 & 10.25 & 5.89 & 2.54 & 3.88 & 3.11 & 2.29 & 2.04 & 1.82 & 1.89 & 1.73 \\
\hline MnO & 0.08 & 0.05 & 0.13 & 0.09 & 0.08 & 0.10 & 0.02 & 0.03 & 0.03 & 0.10 & 0.05 \\
\hline MgO & 1.20 & 1.33 & 4.51 & 0.75 & 1.97 & 1.11 & 0.20 & 0.17 & 0.04 & 0.21 & 0.23 \\
\hline $\mathrm{CaO}$ & 4.15 & 3.76 & 6.45 & 1.10 & 4.57 & 3.57 & 0.11 & 0.21 & 0.06 & 0.26 & 0.40 \\
\hline $\mathrm{Na}_{2} \mathrm{O}$ & 3.47 & 3.63 & 3.14 & 0.43 & 3.56 & 3.45 & 1.80 & 3.01 & 0.96 & 3.36 & 3.83 \\
\hline $\mathrm{K}_{2} \mathrm{O}$ & 2.04 & 1.79 & 1.70 & 7.99 & 2.98 & 2.61 & 6.02 & 6.24 & 6.56 & 4.60 & 5.36 \\
\hline $\mathrm{P}_{2} \mathrm{O}_{5}$ & 0.30 & 0.27 & 0.17 & 0.06 & 0.18 & 0.18 & 0.03 & 0.02 & 0.03 & 0.04 & 0.04 \\
\hline $\mathrm{Cr}_{2} \mathrm{O}_{3}$ & & & 0.02 & 0.00 & 0.00 & 0.00 & 0.00 & 0.00 & 0.00 & 0.00 & 0.00 \\
\hline LOI & 1.90 & 1.99 & 6.10 & 2.70 & 2.60 & 5.20 & 1.70 & 1.70 & 1.00 & 1.80 & 1.20 \\
\hline Total & 100.00 & 100.00 & 100.00 & 100.00 & 100.00 & 100.00 & 100.00 & 100.00 & 100.00 & 100.00 & 100.00 \\
\hline $\mathbf{U}$ & 1.0 & & 1.4 & 2.1 & 2.2 & 1.6 & 2.2 & 1.7 & 2.0 & 1.3 & 1.7 \\
\hline Th & 4.0 & & 4.7 & 12.5 & 6.7 & 6.3 & 13.9 & 15.3 & 12.8 & 12.1 & 13.4 \\
\hline $\mathrm{Zr}$ & 127.0 & & 103.5 & 392.6 & 119.4 & 136.2 & 479.3 & 325.5 & 336.9 & 350.7 & 304.0 \\
\hline Hf & 3.6 & & 2.8 & 10.3 & 3.3 & 3.6 & 12.0 & 9.4 & 9.3 & 8.7 & 8.0 \\
\hline $\mathbf{T a}$ & 0.7 & & 0.3 & 1.4 & 0.6 & 0.7 & 1.6 & 1.6 & 1.5 & 1.0 & 1.3 \\
\hline $\mathrm{Nb}$ & & & 4.0 & 21.0 & 5.6 & 7.4 & 24.1 & 21.1 & 21.7 & 15.8 & 16.8 \\
\hline $\mathbf{Y}$ & & & 11.7 & 39.9 & 11.7 & 12.0 & 49.0 & 36.6 & 40.0 & 30.4 & 24.2 \\
\hline Ba & 1050.0 & & 390.0 & 337.0 & 570.0 & 343.0 & 301.0 & 281.0 & 158.0 & 159.0 & 184.0 \\
\hline Sr & 664.0 & & 536.8 & 56.0 & 699.1 & 201.4 & 23.4 & 17.6 & 21.6 & 23.3 & 15.4 \\
\hline Cs & 0.9 & & 1.3 & 6.4 & 1.1 & 3.7 & 4.3 & 3.8 & 3.4 & 1.4 & 1.7 \\
\hline $\mathbf{R b}$ & 60.8 & & 22.2 & 265.0 & 51.3 & 61.7 & 185.6 & 205.0 & 264.0 & 120.9 & 145.1 \\
\hline $\mathrm{Na}$ & 3.1 & & & & & & & & & & \\
\hline Sb & 0.1 & & & & & & & & & & \\
\hline $\mathrm{Cr}$ & 171.0 & & & & & & & & & & \\
\hline Co & 19.0 & & 17.9 & 1.9 & 9.2 & 5.7 & 0.7 & 1.0 & 0.9 & 1.2 & 0.6 \\
\hline $\mathrm{Ni}$ & 97.0 & & 60.0 & $<20$ & $<20$ & $<20$ & $<20$ & $<20$ & $<20$ & $<20$ & $<20$ \\
\hline Sc & 15.6 & & 16.0 & 7.0 & 10.0 & 5.0 & 7.0 & 4.0 & 3.0 & 4.0 & 3.0 \\
\hline $\mathrm{Fe}$ & 4.3 & & & & & & & & & & \\
\hline La & 30.3 & & 18.9 & 49.9 & 24.5 & 21.4 & 55.3 & 53.0 & 37.4 & 45.7 & 38.0 \\
\hline $\mathrm{Ce}$ & 58.4 & & 39.2 & 104.6 & 47.7 & 42.0 & 116.2 & 103.2 & 72.1 & 91.8 & 78.0 \\
\hline Pr & & & 4.9 & 12.0 & 6.1 & 5.2 & 13.7 & 12.1 & 9.1 & 10.2 & 7.7 \\
\hline Nd & 22.2 & & 18.5 & 42.8 & 23.3 & 19.1 & 48.7 & 40.9 & 31.4 & 34.9 & 28.2 \\
\hline $\mathrm{Sm}$ & 3.8 & & 3.4 & 7.9 & 3.8 & 3.4 & 9.4 & 7.4 & 6.2 & 6.7 & 4.5 \\
\hline Eu & 1.1 & & 1.0 & 0.9 & 1.1 & 0.9 & 1.4 & 0.5 & 0.4 & 0.7 & 0.3 \\
\hline Gd & & & 2.9 & 7.2 & 3.1 & 2.8 & 8.4 & 6.2 & 5.8 & 5.9 & 4.3 \\
\hline $\mathrm{Tb}$ & 0.4 & & 0.4 & 1.2 & 0.4 & 0.4 & 1.4 & 1.1 & 1.1 & 0.9 & 0.7 \\
\hline Dy & & & 2.1 & 7.2 & 2.2 & 2.1 & 8.5 & 6.4 & 6.8 & 5.3 & 4.1 \\
\hline Ho & & & 0.4 & 1.5 & 0.4 & 0.4 & 1.8 & 1.3 & 1.5 & 1.0 & 0.9 \\
\hline Er & & & 1.2 & 4.4 & 1.3 & 1.3 & 5.5 & 4.0 & 4.5 & 3.2 & 2.8 \\
\hline $\mathrm{Tm}$ & & & 0.2 & 0.7 & 0.2 & 0.2 & 0.8 & 0.6 & 0.7 & 0.5 & 0.4 \\
\hline $\mathbf{Y b}$ & 1.0 & & 1.2 & 4.4 & 1.2 & 1.4 & 5.3 & 4.0 & 4.6 & 3.1 & 3.0 \\
\hline Lu & & & 0.2 & 0.7 & 0.2 & 0.2 & 0.8 & 0.6 & 0.7 & 0.5 & 0.5 \\
\hline W & 0.4 & & & & & & & & & & \\
\hline As & 5.4 & & & & & & & & & & \\
\hline Mo & 1.6 & & & & & & & & & & \\
\hline $\mathrm{Br}$ & 0.2 & & & & & & & & & & \\
\hline $\mathrm{Be}$ & & & $<1$ & 4.0 & 2.0 & 1.0 & 3.0 & 3.0 & 2.0 & 3.0 & 2.0 \\
\hline V & & & 129.0 & 41.0 & 104.0 & 66.0 & 37.0 & 22.0 & 26.0 & 27.0 & 16.0 \\
\hline
\end{tabular}

Mo

$\mathrm{Cu}$

$\mathrm{Pb}$

Cd

\begin{tabular}{|c|c|c|c|c|c|c|c|c|c|c|c|}
\hline Ga & & & 14.90 & 15.30 & 15.80 & 15.10 & 17.60 & 16.00 & 13.20 & 15.30 & 15.80 \\
\hline FeOt/MgO & 4.76 & 7.73 & 1.31 & 3.37 & 1.96 & 2.79 & 11.19 & 11.74 & 44.95 & 8.82 & 7.39 \\
\hline $\mathrm{Ba} / \mathrm{La}$ & 34.65 & & 20.63 & 6.75 & 23.27 & 16.03 & 5.44 & 5.30 & 4.22 & 3.48 & 4.84 \\
\hline $\mathrm{La} / \mathrm{Sm}$ & 8.08 & & 5.54 & 6.32 & 6.46 & 6.29 & 5.86 & 7.19 & 6.05 & 6.84 & 8.46 \\
\hline $\mathrm{Sm} / \mathrm{Yb}$ & 3.75 & & 2.84 & 1.82 & 3.24 & 2.52 & 1.78 & 1.86 & 1.35 & 2.13 & 1.51 \\
\hline $\mathbf{E u} / \mathbf{E u}$ * & & & 0.97 & 0.37 & 0.97 & 0.94 & 0.47 & 0.23 & 0.18 & 0.33 & 0.24 \\
\hline $\mathbf{L a} / \mathrm{Yb}$ & 30.30 & & 15.75 & 11.47 & 20.94 & 15.85 & 10.41 & 13.35 & 8.15 & 14.60 & 12.79 \\
\hline Th/Hf & 1.14 & & 1.68 & 1.21 & 2.03 & 1.75 & 1.16 & 1.63 & 1.38 & 1.39 & 1.68 \\
\hline Ta/Hf & 0.21 & & 0.11 & 0.14 & 0.18 & 0.19 & 0.13 & 0.17 & 0.16 & 0.11 & 0.16 \\
\hline La/Ta & 40.62 & & 63.00 & 35.64 & 40.83 & 30.57 & 34.56 & 33.13 & 24.93 & 45.70 & 29.23 \\
\hline Th/La & 0.13 & & 0.25 & 0.25 & 0.27 & 0.29 & 0.25 & 0.29 & 0.34 & 0.26 & 0.35 \\
\hline $\mathrm{Th} / \mathrm{U}$ & 3.96 & & 3.36 & 5.95 & 3.05 & 3.94 & 6.32 & 9.00 & 6.40 & 9.31 & 7.88 \\
\hline $\mathrm{Nb} / \mathrm{Y}$ & & & 0.34 & 0.53 & 0.48 & 0.62 & 0.49 & 0.58 & 0.54 & 0.52 & 0.69 \\
\hline $\mathrm{Dy} / \mathrm{Yb}$ & 0.00 & & 1.75 & 1.66 & 1.85 & 1.56 & 1.61 & 1.60 & 1.48 & 1.68 & 1.38 \\
\hline $\mathrm{Sr} / \mathrm{Y}$ & & & 45.88 & 1.40 & 59.75 & 16.78 & 0.48 & 0.48 & 0.54 & 0.77 & 0.64 \\
\hline $\mathrm{Sr} / \mathrm{Nd}$ & 29.91 & & 29.02 & 1.31 & 30.00 & 10.54 & 0.48 & 0.43 & 0.69 & 0.67 & 0.55 \\
\hline $\mathrm{Nb} / \mathrm{Yb}$ & 0.00 & & 3.33 & 4.83 & 4.79 & 5.48 & 4.54 & 5.31 & 4.73 & 5.05 & 5.66 \\
\hline$[\mathrm{Dy} / \mathrm{Yb}]_{\mathrm{N}}$ & 0.00 & & 1.15 & 1.08 & 1.21 & 1.02 & 1.05 & 1.05 & 0.97 & 1.10 & 0.90 \\
\hline$[\mathrm{La} / \mathrm{Sm}]_{N}$ & 5.05 & & 3.46 & 3.94 & 4.04 & 3.93 & 3.66 & 4.49 & 3.78 & 4.27 & 5.29 \\
\hline$[\mathrm{Gd} / \mathrm{Yb}]_{\mathrm{N}}$ & 0.00 & & 1.94 & 1.34 & 2.16 & 1.65 & 1.28 & 1.27 & 1.02 & 1.52 & 1.18 \\
\hline$[\mathrm{La} / \mathrm{Yb}]_{N}$ & 20.58 & & 10.70 & 7.79 & 14.23 & 10.77 & 7.07 & 9.07 & 5.54 & 9.92 & 8.69 \\
\hline$[\mathrm{Sm} / \mathrm{Yb}]_{\mathrm{N}}$ & 4.08 & & 3.09 & 1.98 & 3.52 & 2.74 & 1.93 & 2.02 & 1.46 & 2.32 & 1.64 \\
\hline
\end{tabular}




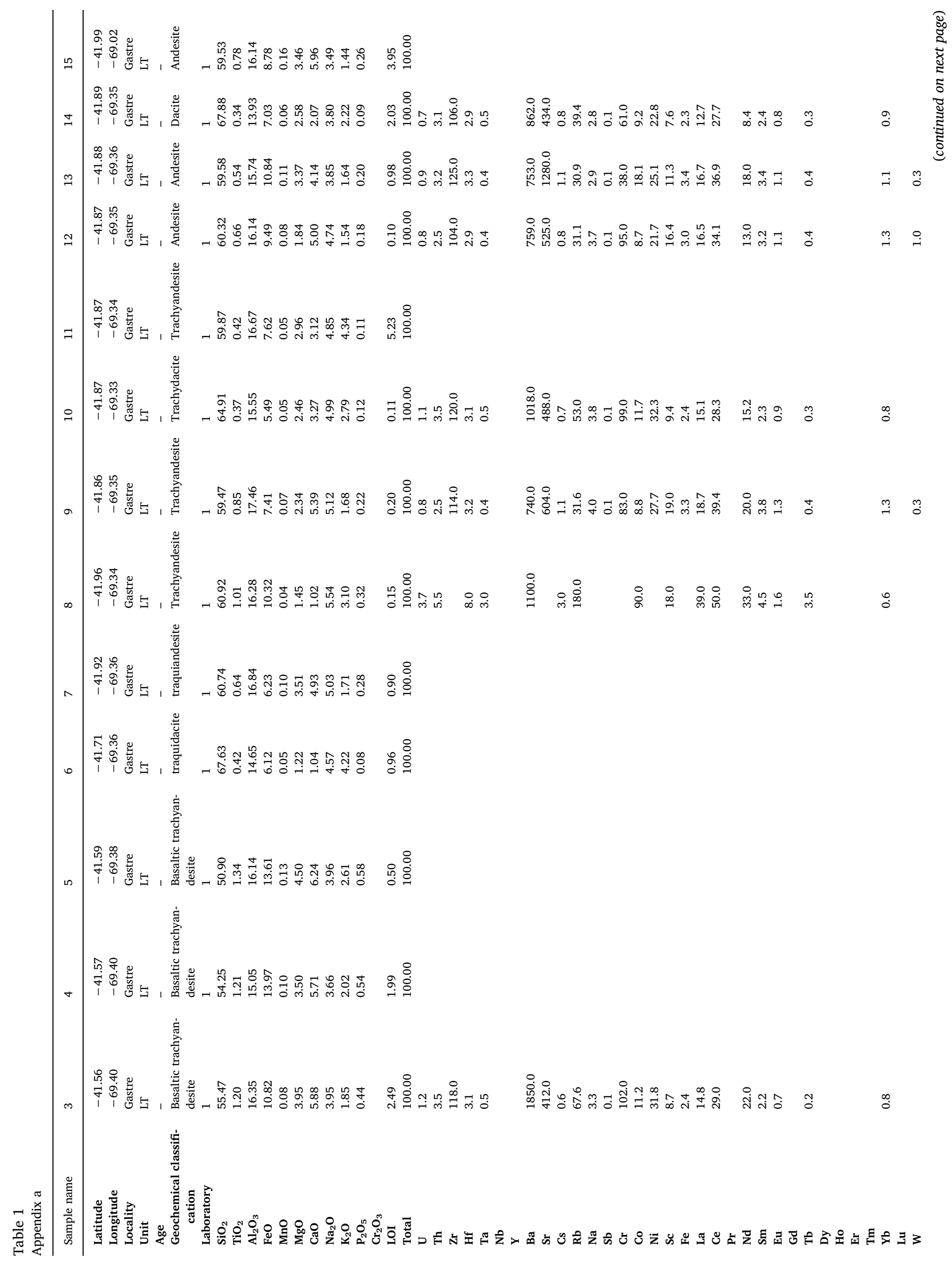



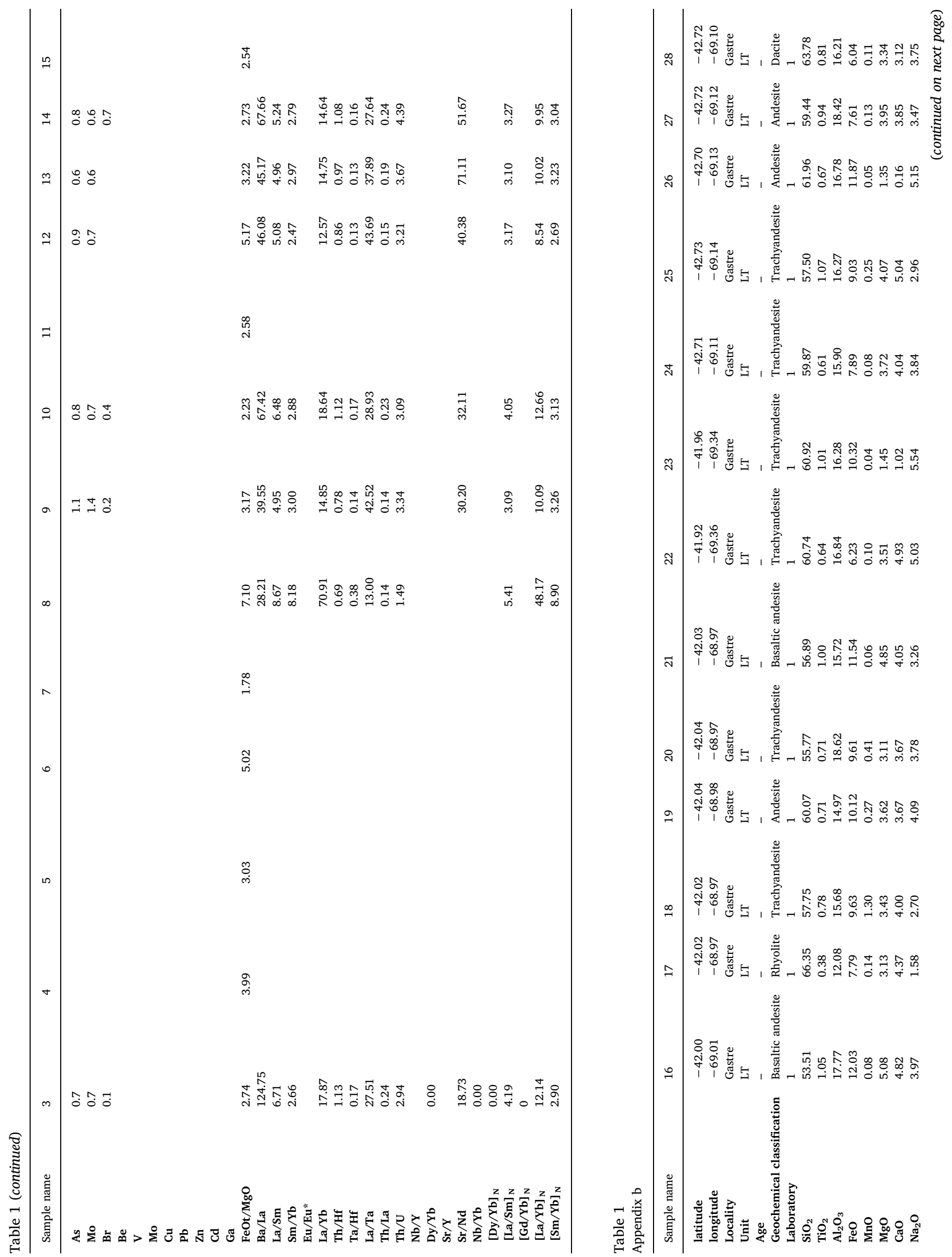


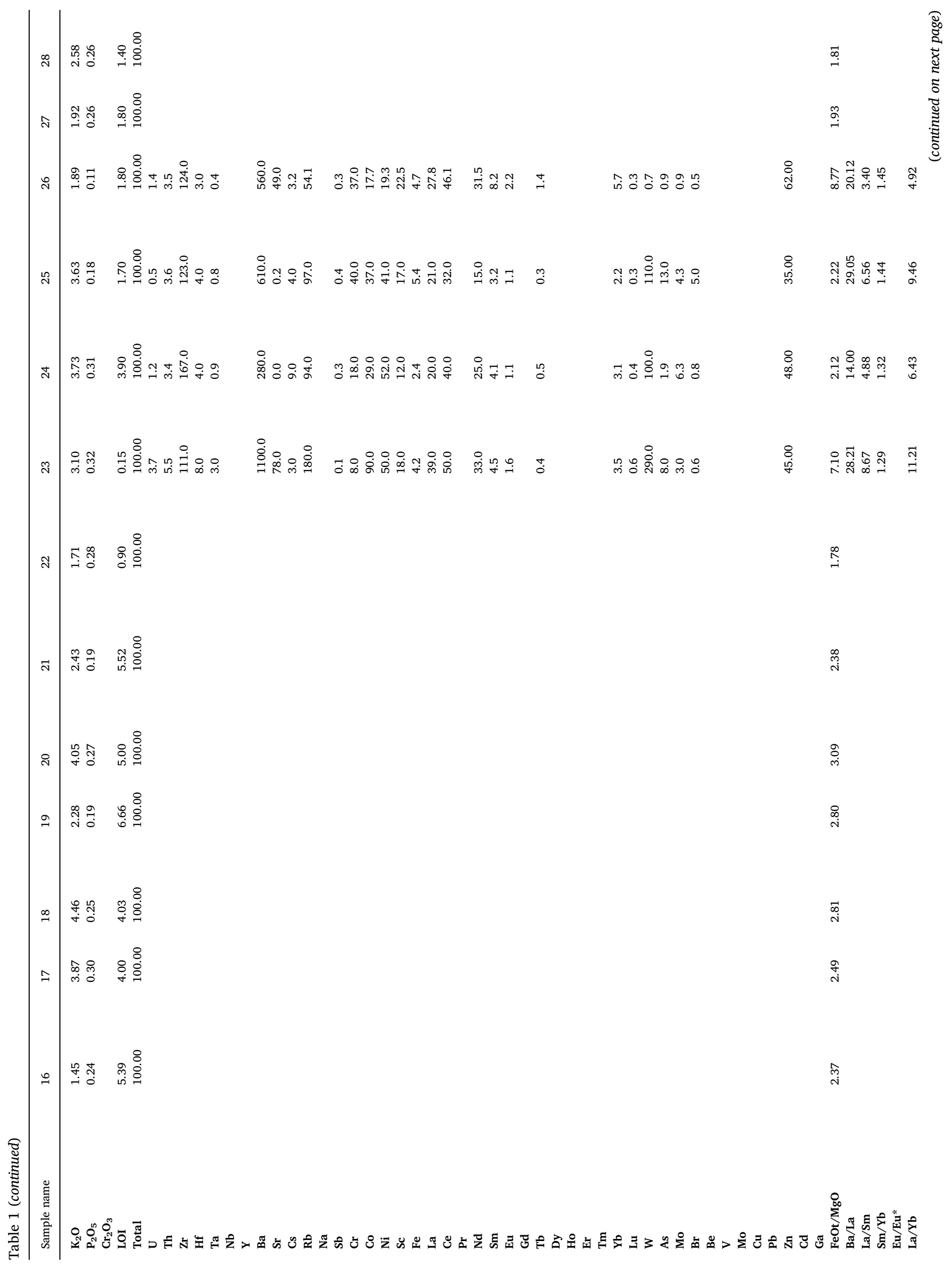




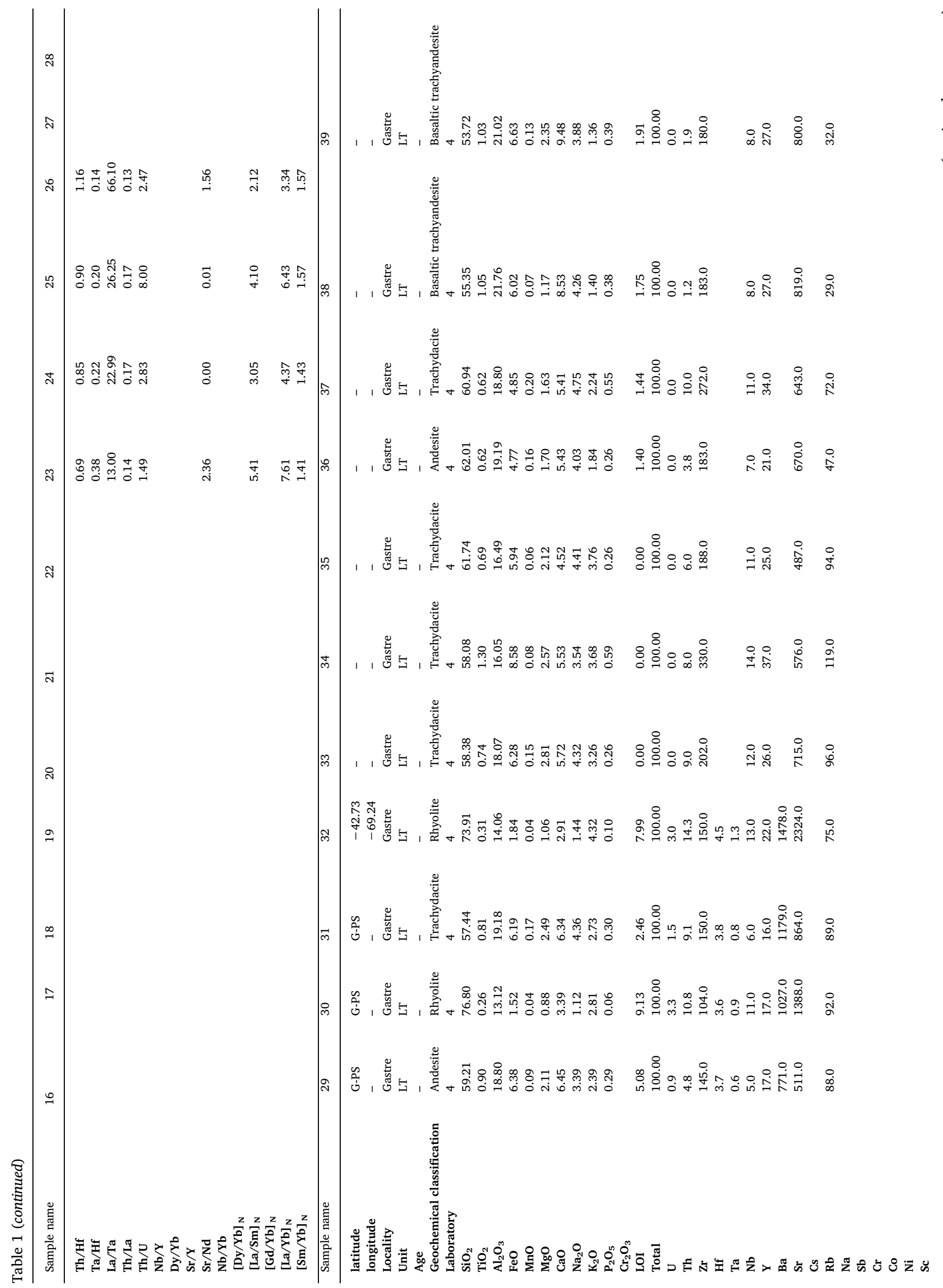




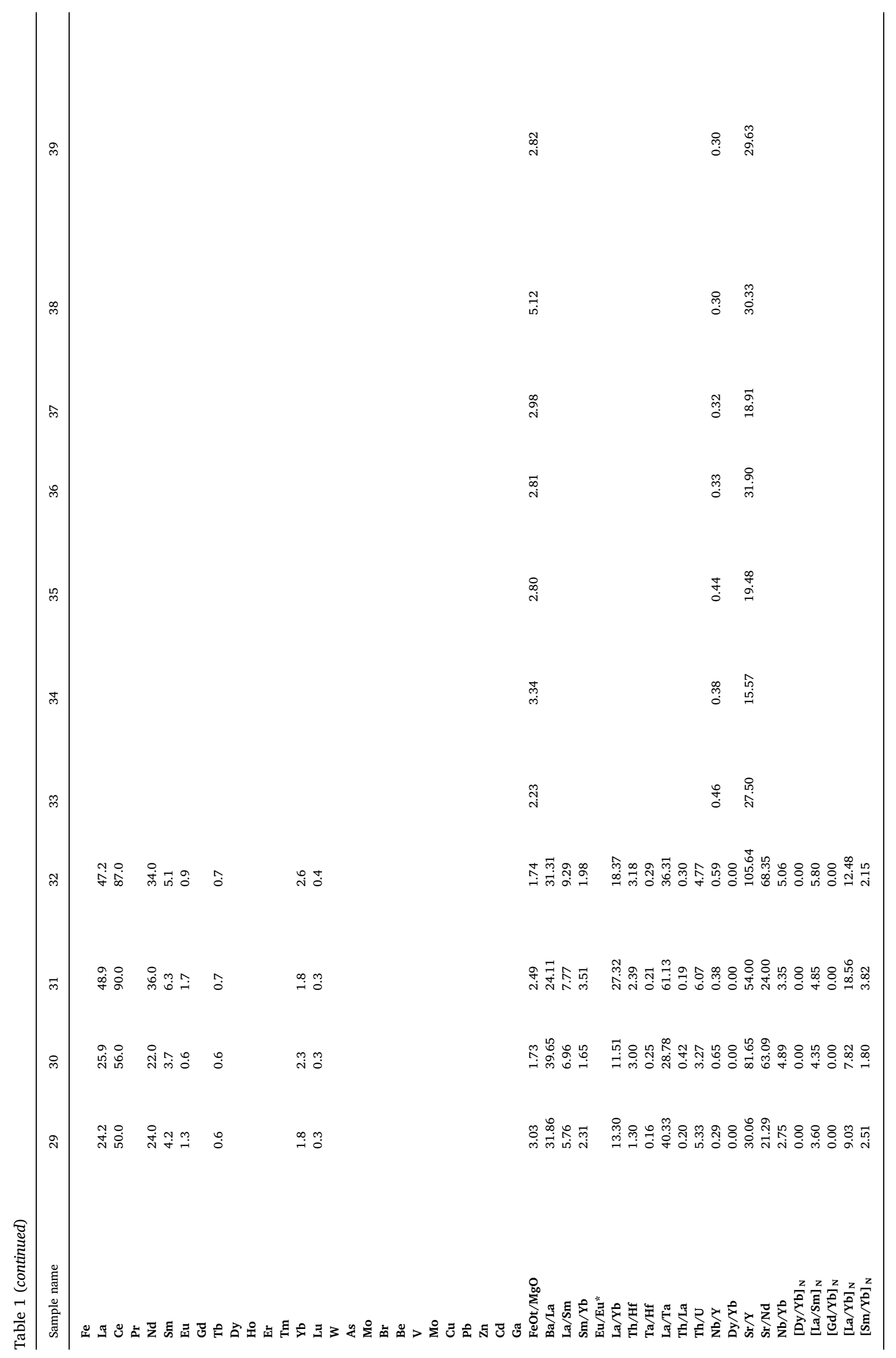




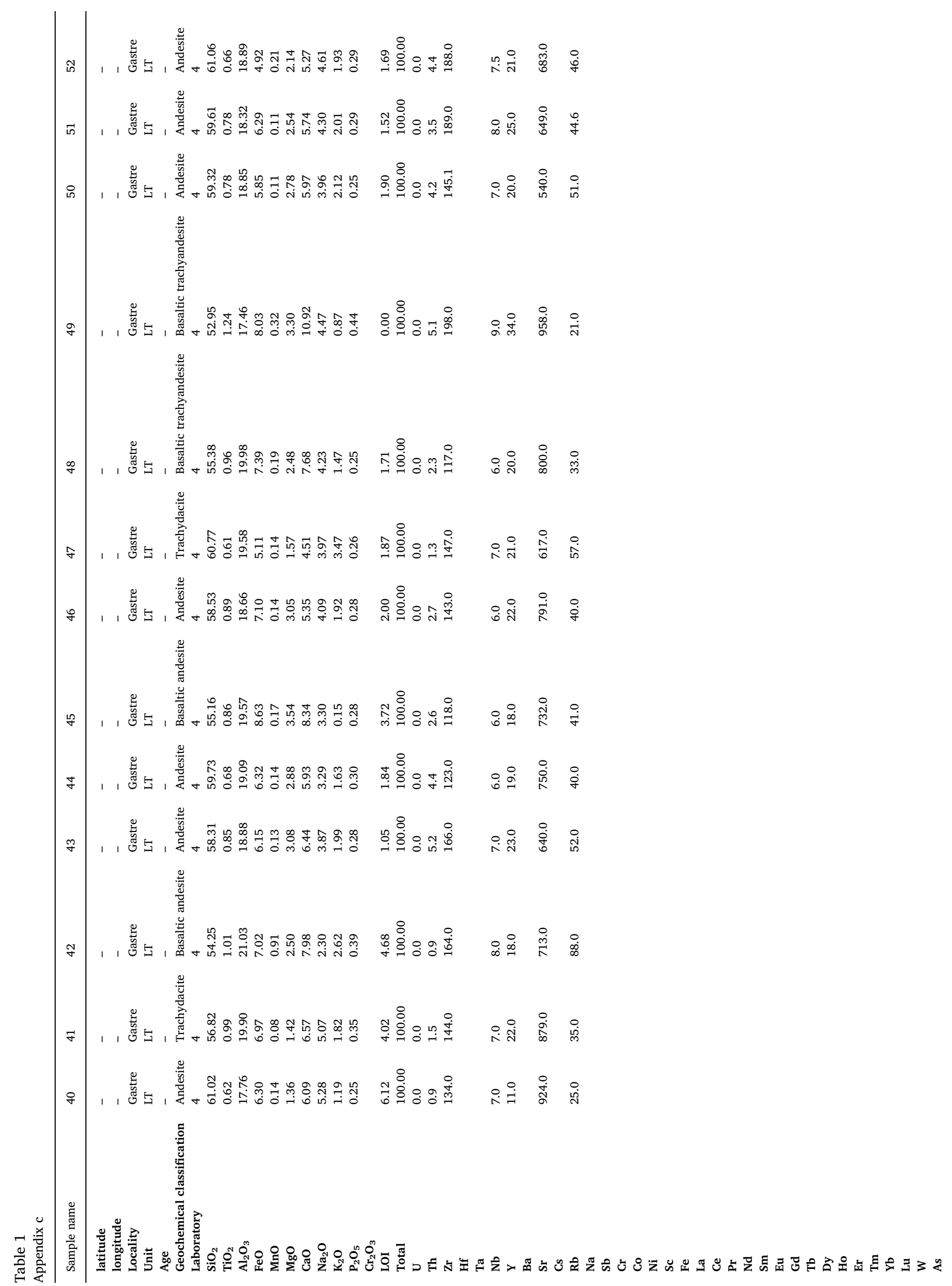




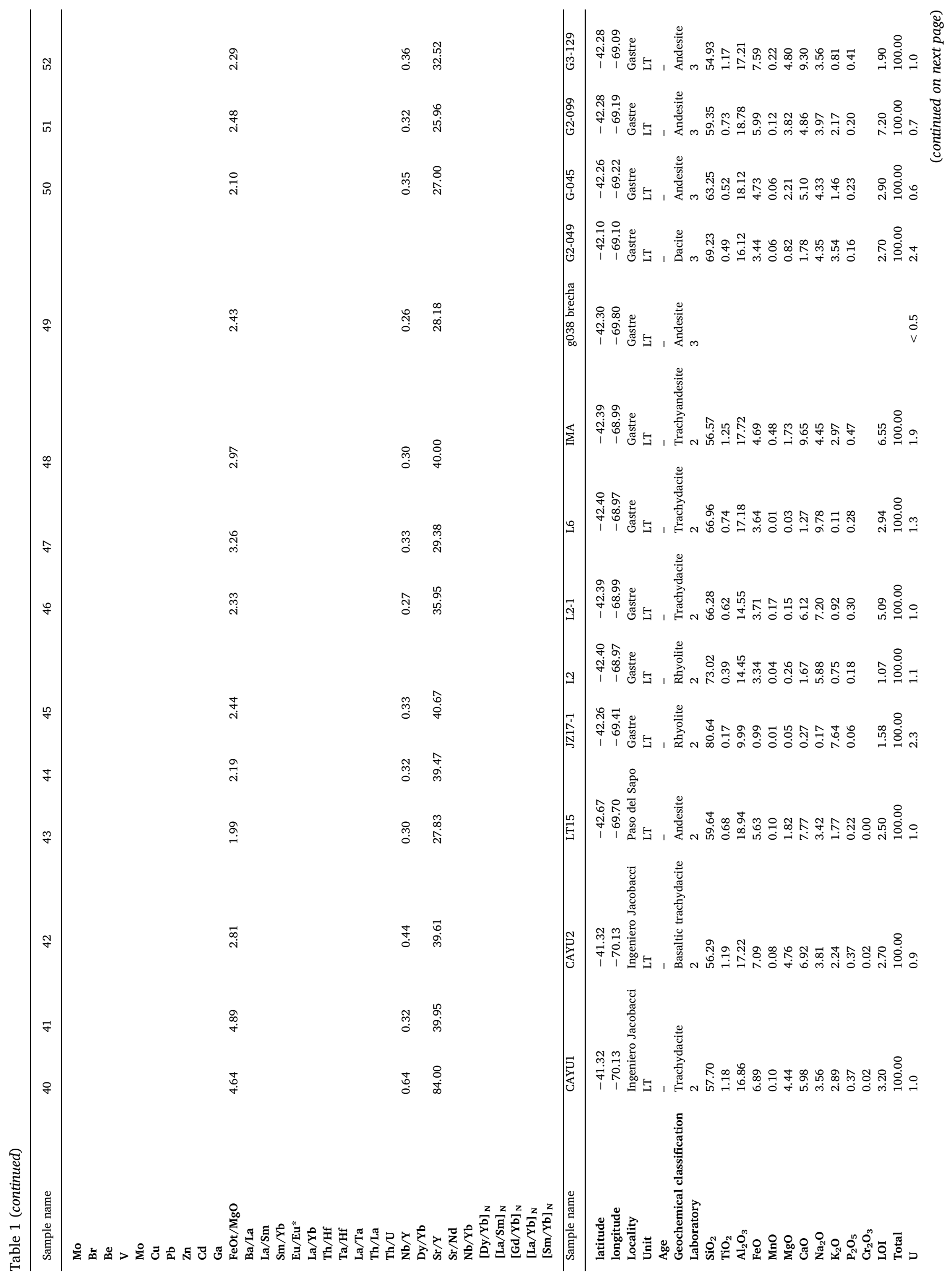




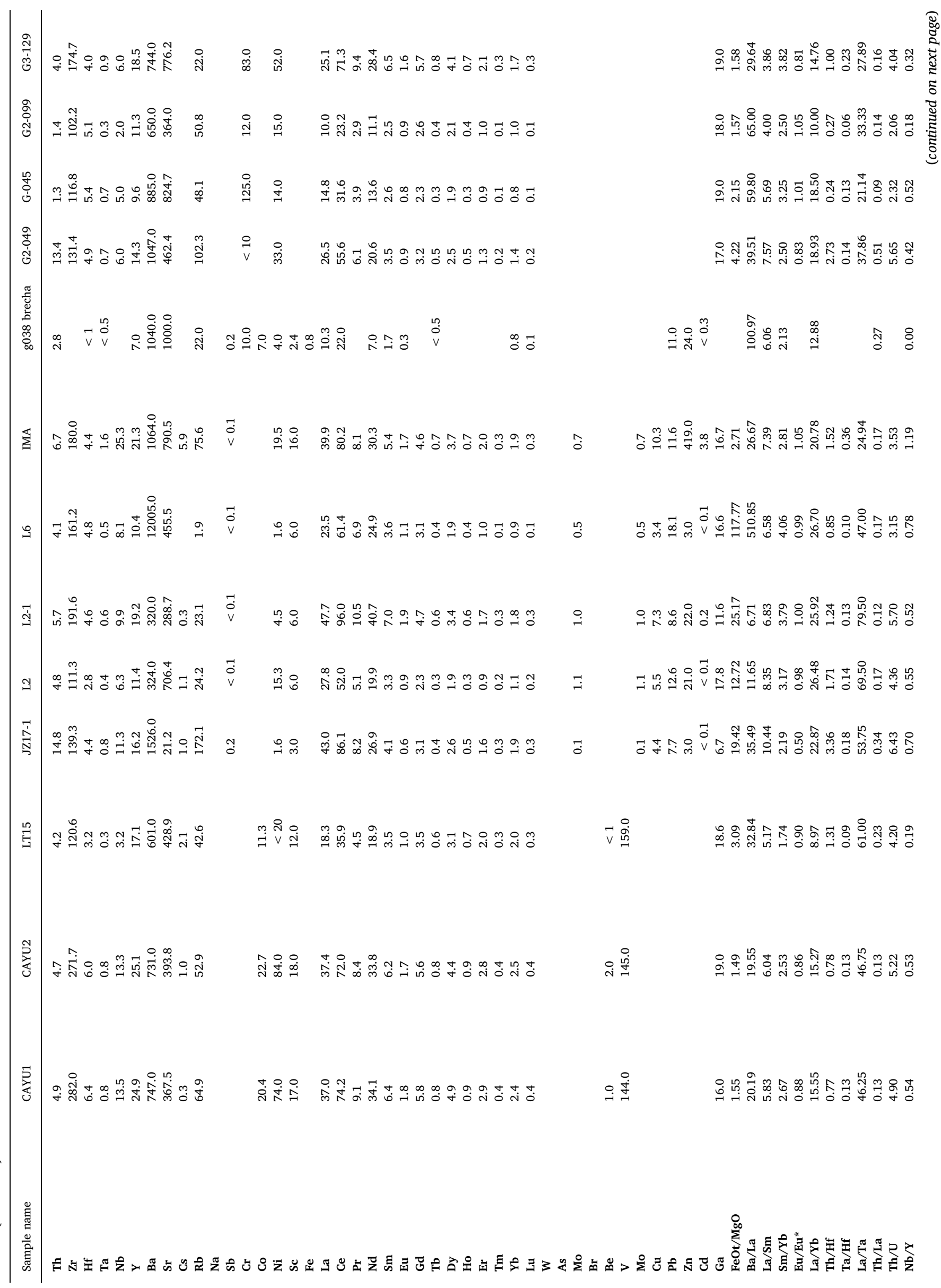




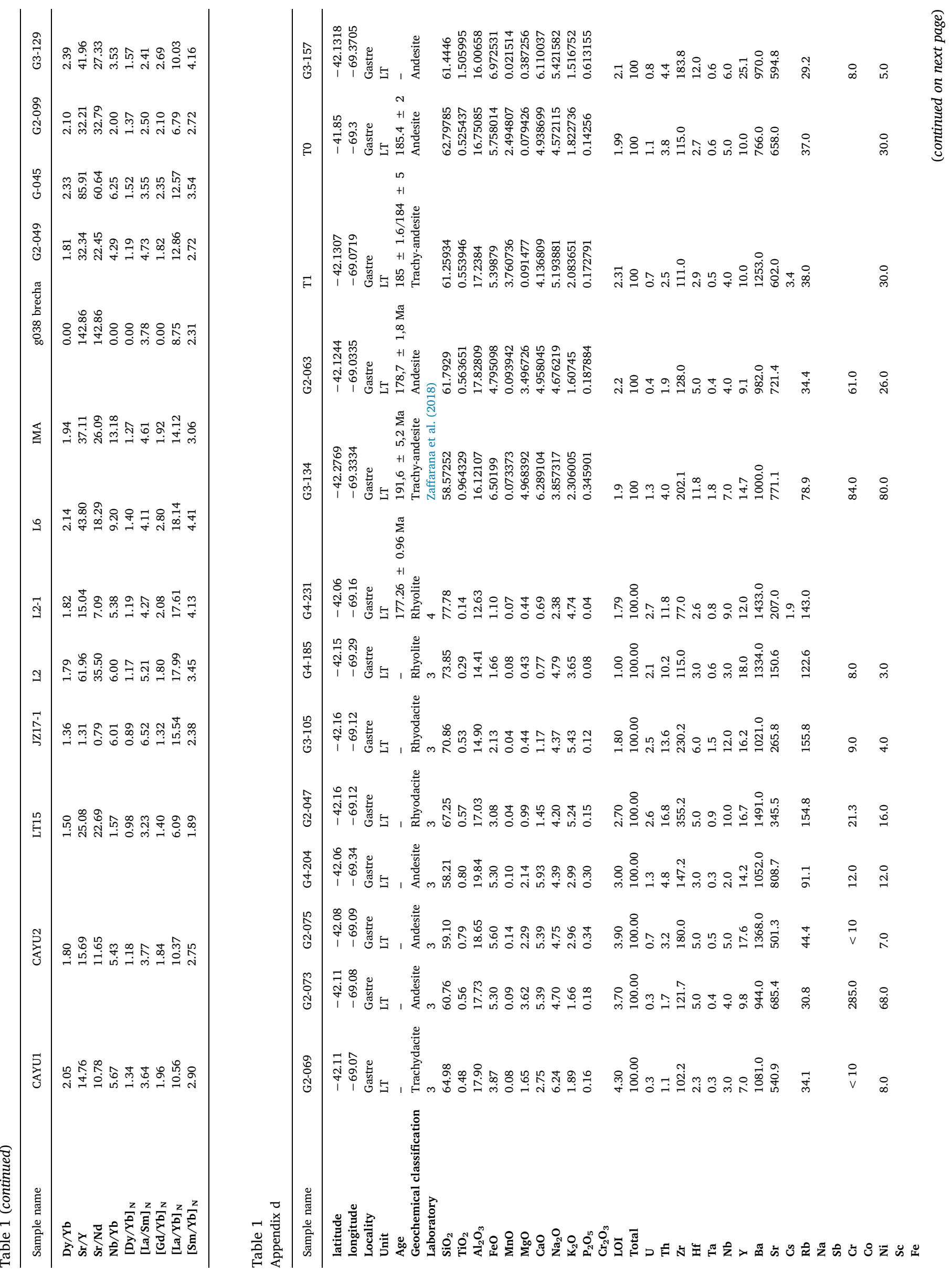




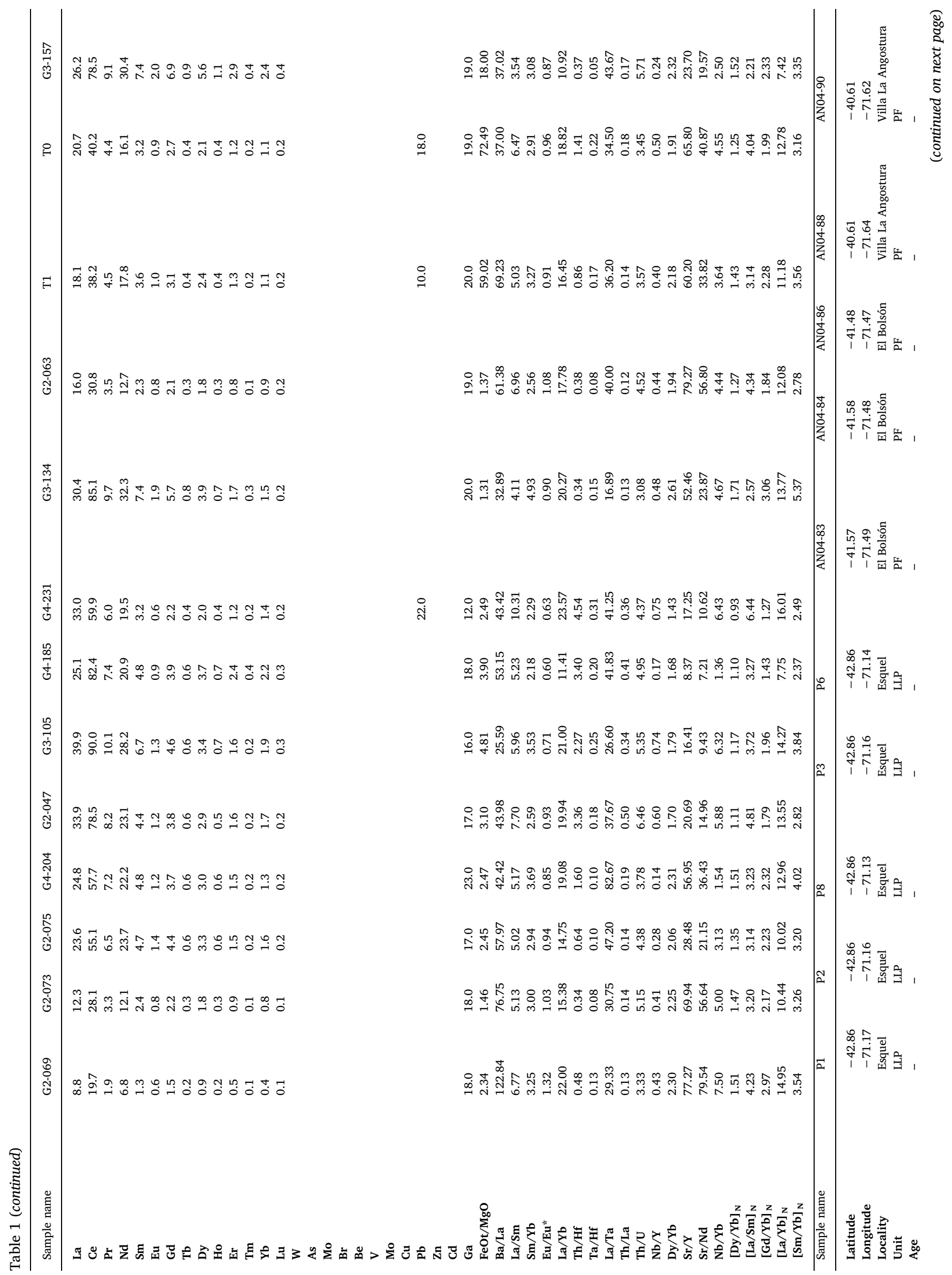




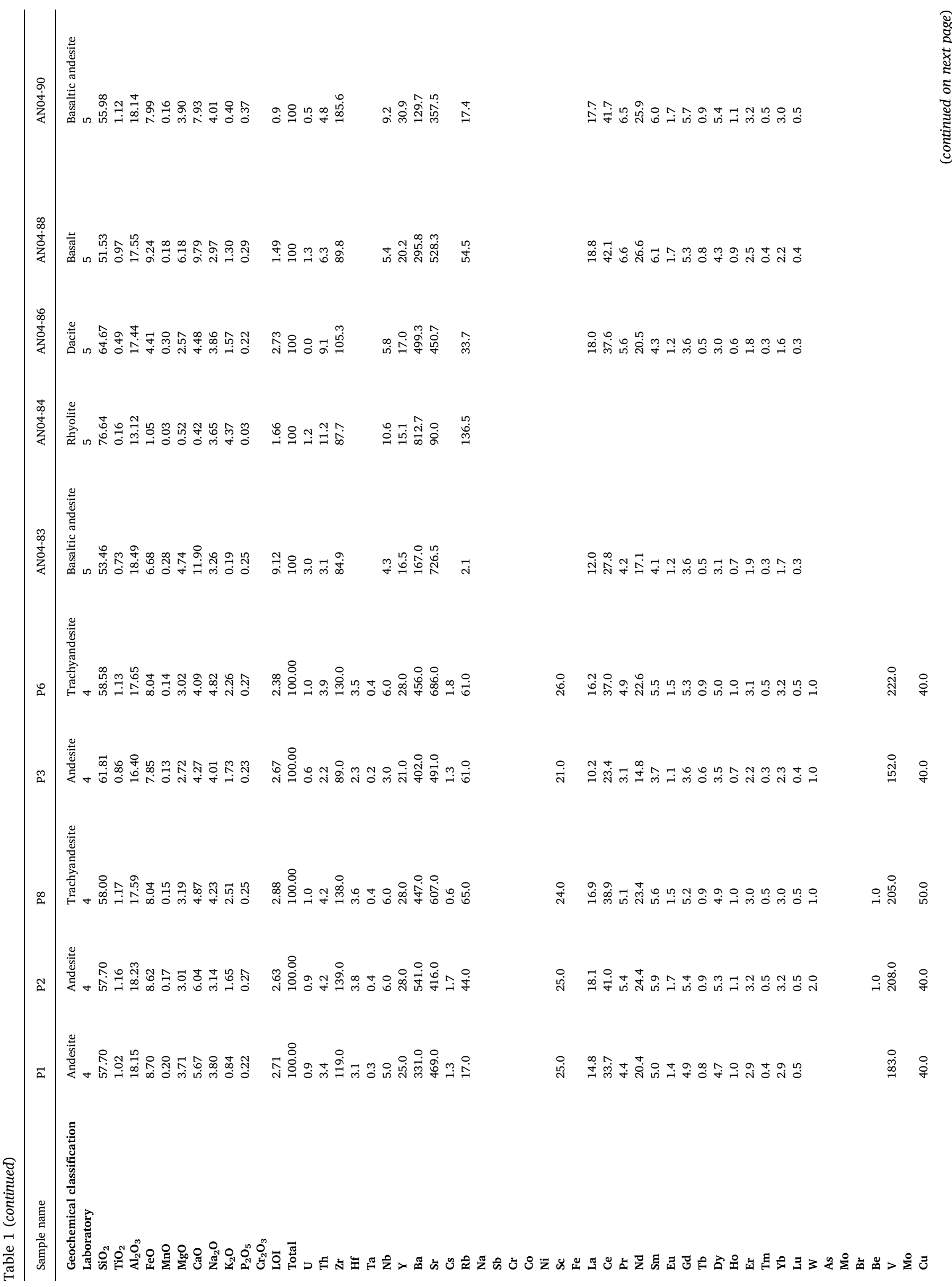




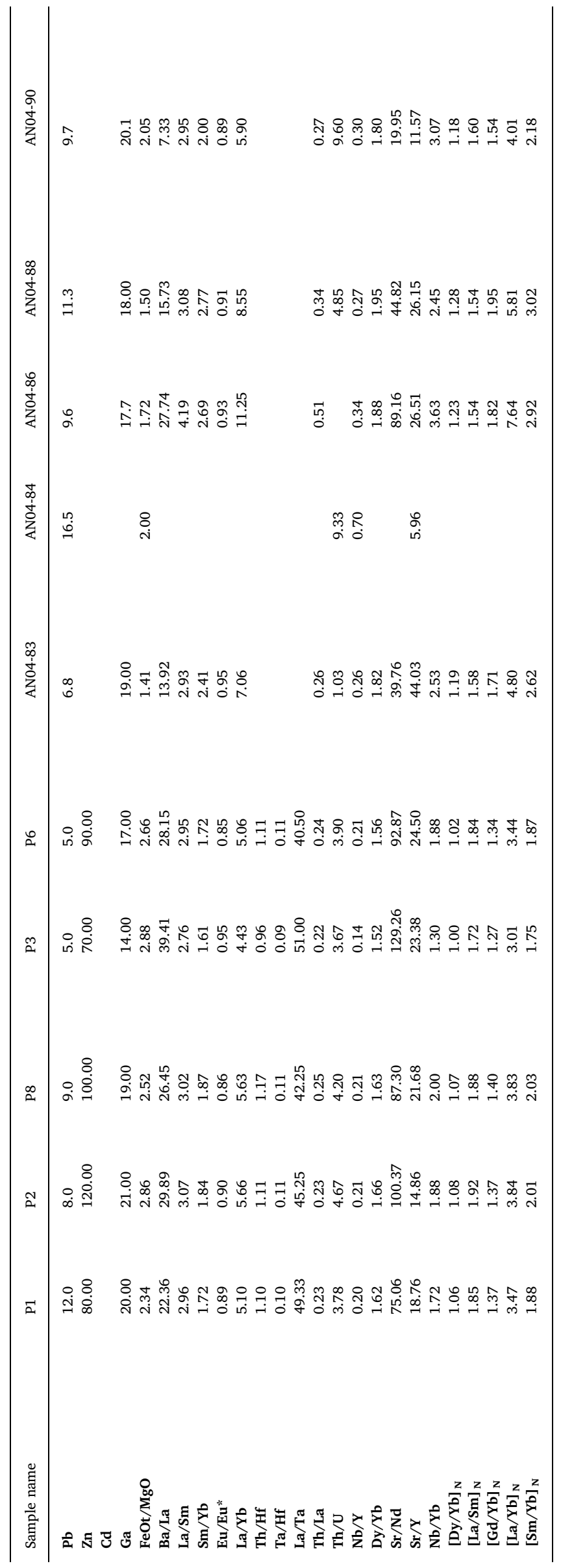

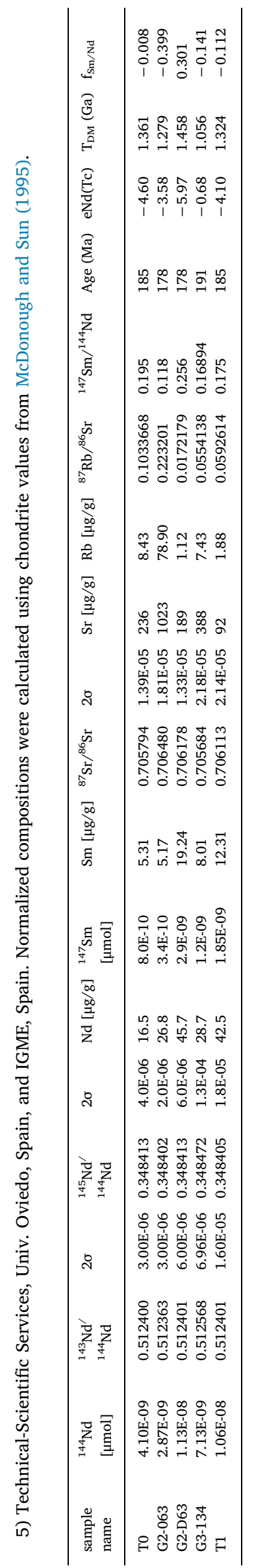




\section{Author statement}

All persons who meet authorship criteria are listed as authors, and all authors certify that they have participated sufficiently in the work to take public responsibility for the content, including participation in the concept, design, analysis, writing, or revision of the manuscript.

\section{References}

Alric, V.I., Haller, M.J., Feraud, G., Bertand, H., Zubia, M., 1996. Cronología ${ }^{40} \mathrm{Ar} /{ }^{39} \mathrm{Ar}$ del vulcanismo jurasico de la Patagonia extraandina. In: Actas del XIII Congreso Geológico Argentino, vol. 5. Buenos Aires, Tomo, pp. 243-250.

Annen, C., 2009. From plutons to magma chambers: thermal constraints on the accumulation of eruptible silicic magma in the upper crust. Earth Planet Sci. Lett. 284 (3-4), 409-416. https://doi.org/10.1016/j.epsl.2009.05.006.

Annen, C., Sparks, R.S.J., 2002. Effects of repetitive emplacement of basaltic intrusions on thermal evolution and melt generation in the crust. Earth Planet Sci. Lett. 203 (3-4), 937-955. https://doi.org/10.1016/S0012-821X(02)00929-9.

Aragón, E., González, P.D., Aguilera, Y.E., Cavarozzi, C., Llambías, E.J., 2000. Andesitas Alvar: volcanismo alcalino jurásico en el área de Paso del Sapo, provincia del Chubut. Rev. Asoc. Geol. Argent. 55 (12), 44-58.

Aravena, A., Gutiérrez, F.J., Parada, M.A., Payacan, I., Bachmann, O., Poblete, F., 2017. Late-stage magma flow in a shallow felsic reservoir: Merging the anisotropy of magnetic susceptibility record with numerical simulations in La Gloria Pluton, central Chile. Lithos 284-285, 578-587. https://doi.org/10.1002/jgrb.50164.

Ayalew, D., Ishiwatari, A., 2011. Comparison of rhyolites from continental rift, continental arc and oceanic island arc: Implication for the mechanism of silicic magma generation. Isl. Arc 20 (1), 78-93. https://doi.org/10.1111/j.1440-1738.2010. 00746.x.

Bachmann, O., Bergantz, G.W., 2008. Rhyolites and their source mushes across tectonic settings. J. Petrol. 49 (12), 2277-2285. https://doi.org/10.1093/petrology/egn068.

Baker, P.E., Rea, W.J., Skarmeta, J., Caminos, R., Rex, D.C., 1981. Igneous history of the andean Cordillera and Patagonian plateau around Latitude 46 degrees S. Phil. Trans. Roy. Soc. Lond.: Mathematical, Physical and Engineering Sciences 303 (1474), 105-149. https://doi.org/10.1098/rsta.1981.0194.

Benedini, L., Gregori, D., 2012. La Formación Garamilla: evento volcánico del Jurásico Inferior del sector Occidental de la Comarca Nordpatagónica, Provincia de Río Negro , Argentina. 2. Aportes Al Magmatismo y Metalogénesis Asociada I - 1. Ser. Correlación Geol. 28 (1), 131-144.

Benedini, L., Gregori, D., 2013. Significance of the early jurassic Garamilla Formation in the western Nordpatagonian massif. J. S. Am. Earth Sci. 45, 259-277. https://doi. $\operatorname{org} / 10.1016 /$ j.jsames.2013.03.016.

Blesa, A., 2004. Geology and Mineralization of the Esquel Area, Patagonia, Argentina. Ph.D. Thesis. Colorado School of Mines.

Bouhier, V.E., Franchini, M.B., Caffe, P.J., Maydagán, L., Rapela, C.W., Paolini, M., 2017. Petrogenesis of volcanic rocks that host the world-class Ag-Pb Navidad district, North Patagonian massif: comparison with the jurassic Chon Aike volcanic province of Patagonia, Argentina. J. Volcanol. Geoth. Res. 338, 101-120. https://doi.org/10. 1016/j.jvolgeores.2017.03.016.

Bruce, R.M., Nelson, E.P., Weaver, S.G., Lux, D.R., 1991. Temporal and spatial variations in the southern Patagonian batholith; Constraints on magmatic arc development. In: In: Harmon, C.W., Rapela, R.S. (Eds.), Andean Magmatism and its Tectonic Setting, vol. 265. Special Paper-Geological Society of America, Boulder, Colorado, pp. 1-12.

Busteros, A., Franchi, M., Lema, H.A., 1993. E1 magmatismo calcoalcalino del área de José de San Martín, provincia del Chubut. In: XII Congreso Geológico Argentino, Actas IV, pp. 128-133 (Mendoza).

Castro, A., Moreno-Ventas, I., Fernández, C., Vujovich, G., Gallastegui, G., Heredia, N., Martino, R., Becchio, R., Corretgé, L.G., Díaz-Alvarado, J., Such, P., García-Arias, M., Liu, D., 2011a. Petrology and SHRIMP U-Pb zircon geochronology of Cordilleran granitoids of the Bariloche area, Argentina. J. S. Am. Earth Sci. 32 (4), 508-530. https://doi.org/10.1016/j.jsames.2011.03.011.

Castro, A., Aragón, E., Díaz-Alvarado, J., Blanco, I., García-Casco, A., Vogt, K., Liu, D.-Y., 2011b. Age and composition of granulite xenoliths from Paso de Indios, Chubut province, Argentina. J. S. Am. Earth Sci. 32 (4), 567-574. https://doi.org/10.1016/j. jsames.2011.03.011.

Cawood, P.A., 2005. Terra Australis orogen: Rodinia breakup and development of the Pacific and Iapetus margins of Gondwana during the neoproterozoic and paleozoic Earth Sci. Rev. 69, 249-279.

Cawood, P.A., Buchan, C., 2007. Linking accretionary orogenesis with supercontinent assembly. Earth Sci. Rev. 82, 217-256. https://doi.org/10.1016/j.earscirev.2007.03. 003.

Christiansen, E.H., 2005. Contrasting processes in silicic magma chambers: evidence from very large volume ignimbrites. Geol. Mag. 142, 669-681.

Christiansen, E.N., McCurry, M., 2008. Contrasting origins of Cenozoic silicic volcanic rocks from the western Cordillera of the United States. Bull. Volcanol. 70, 251-267.

Cortés, J.M., 1981. El substrato precretácico del extremo noreste de la Provincia del Chubut. Rev. Asoc. Geol. Argent. 36 (3), 217-235.

Cribb, J., Barton, M., 1996. Geochemical effects of decoupled fractional crystallization and crustal assimilation. Lithos 37 (95), 293-307.

Cúneo, R., Ramezani, J., Scasso, R., Pol, D., Escapa, I., Zavattieri, A.M., Bowring, S.A., 2013. High-precision U-Pb geochronology and a new chronostratigraphy for the Cañadón Asfalto Basin, Chubut, central Patagonia: implications for terrestrial faunal and floral evolution in Jurassic. Gondwana Res. 24 (3-4), 1267-1275. https://doi. org/10.1016/j.gr.2013.01.010.
D'Elia, L., Muravchik, M., Franzese, J.R., Bilmes, A., 2012. Volcanismo de sin-rift de la Cuenca Neuquina, Argentina: relación con la evolución Triásico Tardío-Jurásico Temprano del margen andino. Andean Geol. 39, 106-132.

D'Elia, L., Bilmes, A., Franzese, J.R., Veiga, G.D., Hernández, M., Muravchik, M., 2015. Early evolution of the southern margin of the Neuquén Basin, Argentina: tectonostratigraphic implications for rift evolution and exploration of hydrocarbon plays. Journal of South America Earth Sciences 64, 42-57.

Davidson, J., Turner, S., Plank, T., 2013. Dy/Dy*: variations arising from mantle sources and petrogenetic processes. J. Petrol. 54 (3), 525-537. https://doi.org/10.1093/ petrology/egs076.

De La Cruz, R., Suárez, M., 1997. El Jurásico de la cuenca de Neuquén en Lonquimay, Chile: Formación Nacientes del Biobío (38-39 S). Rev, Geol. Chile 24 (1), 3-24.

De Paolo, D.J., 1981. Trace elements and isotopic effects of combined wallrock assimilation and fractional crystallisation. Earth Planet Sci. Lett. 53, 189-202.

De Paolo, D.J., Linn, A.M., Schubert, G., 1991. The continental crustal age distribution: methods of determining mantle separation ages from Sm-Nd isotopic data and application to the southwestern United States. J. Geophys. Res. 96 (B2), 2071-2088. https://doi.org/10.1029/90JB02219.

Deer, W., Howie, R., Zussman, J., 2013. An Introduction to the Rock-Forming Minerals, $3^{\text {rd }}$. edition. The Mineralogical Society, London.

Dejonghe, L., Darras, B., Hughes, G., Muchez, P., Scoates, J.S., Weis, D., 2002. Isotopic and fluid-inclusion constraints on the formation of polymetallic vein deposits in the Central Argentinian Patagonia. Miner. Deposita 37 (2), 158-172. https://doi.org/10. 1007/s00126-001-0225-8.

Echaurren, A., Oliveros, V., Folguera, A., Ibarra, F., Creixell, C., Lucassen, F., 2017. Early Andean tectonomagmatic stages in north Patagonia: insights from field and geochemical data. J. Geol. Soc. 174 (3), 405-421. https://doi.org/10.1144/jgs2016-087.

Ersoy, Y., Helvaci, C., 2010. FC - AFC - FCA and mixing modeler: a Microsoft s Excel and spreadsheet program for modeling geochemical differentiation of magma by crystal fractionation, crustal assimilation and mixing. Comput. Geosci. 36, 383-390. https:// doi.org/10.1016/j.cageo.2009.06.007.

Franchi, M., Page, R., 1980. Los basaltos Cretácicos y la evolución magmática del Chubut Occidental. Rev. Asoc. Geol. Argent. 35 (2), 208-229.

Franzese, J.R., Pankhurst, R.J., Rapela, C.W., Spalletti, L.A., Fanning, M., Muravchik, M., 2002. Nuevas evidencias geocronológicas del magmatismo gondwánico en el Noroeste del Macizo Norpatagonico. Actas Del XV Congreso Geológico Argentino, El Calafate, pp. 1-5.

Franzese, J.R., Veiga, G.D., Schwarz, E., Gómez-Pérez, I., 2006. Tectonostratigraphic evolution of a Mesozoic graben border system: the Chachil depocentre, southern Neuquén Basin, Argentina. J. Geol. Soc. 163, 707-721.

Freytes, E., 1971. Informe geológico preliminar sobre la Sierra de Tepuel (Deptos. Languiñeo y Tehuelches. prov. de Chubut), Buenos Aires.

Furlong, K.P., Chapman, D.S., 2013. Heat flow, heat generation, and the thermal state of the Lithosphere. Annu. Rev. Earth Planet Sci. 41 (1), 385-410. https://doi.org/10. 1146/annurev.earth.031208.100051.

Ghiara, M., Haller, M.J., Stanzione, D., Barbieri, M., Menditti, I., Castorina, F., Meister, C.M., 1999. Calc-alkaline volcanic rocks from cerro ver, Patagonian Cordillera $\left(43^{\circ} 10^{\prime} \mathrm{S}\right)$ : Geochemistry and geochronology. In: $14^{\circ}$ Congreso Geológico Argentino, vol. 2. pp. 178-181 Actas.

Giacosa, R.E., 1986. Prospección y exploración minera en el Cordón Tres Morros, Cerro Granito y Cerro del Medio, Cordillera Nordpatagónica. Comodoro Rivadavia.

Giacosa, R., Heredia Carballo, N., 2001. Hoja Geológica 4172-IV San Carlos de Bariloche, vol. 279 Boletín $\mathrm{N}^{\circ}$, Buenos Aires.

González, P.D., Coluccia, A., Franchi, M., 1999. Geología y Recursos Minerales de la Hoja 4169-III 'Ingeniero Jacobacci' (provincia de Río Negro). Escala: 1:250.000. Boletín N $^{\circ}$ 311, Buenos Aires.

González, S.N., Greco, G.A., González, P.D., Sato, A.M., Llambías, E.J., Varela, R., Basei, M.A.S., 2014. Geología, petrografía y edad u-pb de un enjambre longitudinal no-se de diques del Macizo Nordpatagónico oriental, Río Negro. Rev. Asoc. Geol. Argent. 71 (2), 174-183.

González, S.N., Greco, G.A., Sato, A.M., Llambías, E.J., Basei, M.A.S., González, P.D., Díaz, P.E., 2016. Middle Triassic trachytic lava flows associated with coeval dyke swarm in the North Patagonian Massif: a postorogenic magmatism related to extensional collapse of the Gondwanide orogen. J. S. Am. Earth Sci. 75, 134-143. https:// doi.org/10.1016/j.jsames.2017.02.007.

González, S.N., Greco, G.A., Sato, A.M., Llambías, E.J., Basei, M.A.S., González, P.D., Díaz, P.E., 2017. Middle Triassic trachytic lava flows associated with coeval dyke swarm in the North Patagonian Massif: a postorogenic magmatism related to extensional collapse of the Gondwanide orogen. J. S. Am. Earth Sci. 75, 134-143. https:// doi.org/10.1016/j.jsames.2017.02.007.

Gordon, A., Ort, M.H., 1993. Edad y correlación del plutonismo subcordillerano en las provincias de Río Negro y Chubut $\left(41^{\circ}-42^{\circ} 30^{\prime}\right.$ L.S.). In: XII Congreso Geológico Argentino y II Congreso de Exploración de Hidrocarburos, vol. IV. pp. 120-127. https://doi.org/10.1017/CBO9781107415324.004.

Gulisano, C.A., Gutiérrez Pleimling, A., Digregorio, R.E., 1984. Esquema estratigráfico de la secuencia jurásica del oeste de la provincia del Neuquén. In: $9^{\circ}$ Congreso Geológico Argentino, Actas, vol. 1. pp. 236-259 Buenos Aires.

Gust, D.A., Biddle, K.T., Phelps, D.W., Uliana, M.A., 1985. Associated middle to late 
Jurassic volcanism and extension in southern South America. Tectonophysics 116, 223-253.

Haller, M.J., Lapido, O.R., 1982. The jurassic-Cretaceous volcanism in the septentrional Patagonian Andes. Earth Sci. Rev. 18 (3-4), 395-410. https://doi.org/10.1016/00128252(82)90046-0.

Haller, M.J., Linares, E., Ostera, H., Page, S., 1999. Petrology and Geochronology of the Sub-cordilleran Plutonic Belt of Patagonia. II South American Symposium on Isotope Geology. pp. 210-214.

Herbst, R., 1966. La flora liásica del Grupo Pampa de Agnia, Chubut, Patagonia. Ameghiniana 4 (9), 337-349.

Hervé, F., Calderón, M., Fanning, C.M., Pankhurst, R.J., Rapela, C.W., Quezada, P., 2018. The country rocks of Devonian magmatism in the north Patagonian massif and Chaitenia. Andean Geol. 45 (3), 301-317. https://doi.org/10.5027/andgeoV45n33117.

Hildreth, W., Moorbath, S., 1988. Crustal contributions to arc magmatism in the Andes of Central Chile. Contrib. Mineral. Petrol. 98, 455-489.

Hinz, K., Neben, S., Schreckenberger, B., Roeser, H.A., Block, M., Souza, K.G., Meyer, H., 1999. The Argentine continental margin north of $48^{\circ} \mathrm{S}$ : sedimentary successions, volcanic activity during breakup. Mar. Petrol. Geol. 16, 1-25.

Hooper, P.R., Bailey, D.G., McCarley Holder, G.A., 1995. Tertiary calc-alkaline magmatism associated with lithospheric extension in the Pacific Northwest. J. Geophys. Res. 100 (7), 303-310 319.

Introcaso, A., 2003. Significativa descompensación isostática en la Cuenca del Colorado (República Argentina). Revista de la Asociación Geológica Argentina FALTA EL VOLUMEN, pp. 474-478.

Introcaso, A., Ramos, V.A., 1984. La Cuenca del Salado: un modelo de evolución aulacogénica. In: $9^{\circ}$ Congreso Geológico Argentino. San Carlos de Bariloche, Argentina, pp. 27-46.

Irvine, T.N., Baragar, W.R.A., 1971. A guide to the chemical classification of the common volcanic rocks. Can. J. Earth Sci. 8, 523-548.

Kay, S.M., Burns, W.M., Copeland, P., Mancilla, O., 2006. Upper Cretaceous to Holocene magmatism and evidence for transient Miocene shallowing of the Andean subduction zone under the northern Neuquén Basin. Geol. Soc. Am. Spec. Pap. 407, 19-60. https://doi.org/10.1130/2006.2407(02. 2407 (02

Keidel, J., 1921. Sobre la distribución de los depósitos glaciares del Pérmico conocidos en la Argentina y su significación para la estratigrafía de la serie del Gondwana y la paleogeografía del Hemisferio Austral. 25. Academia Nacional de Ciencias, pp. 239-368 Córdoba.

Lagorio, S., Busteros, A., Silva Nieto, D., Giacosa, R., Zaffarana, C., Márquez, M., 2018. New Early Jurassic U-Pb age in rhyolitic dykes from the northeastern sector of Gastre (Chubut, Argentina) and its possible relation to the mineralization of the Los Manantiales district. In: 15th Quadriennial IAGOD Symposium.

Lee, C.T.A., Morton, D.M., Farner, M.J., Moitra, P., 2015. Field and model constraints on silicic melt segregation by compaction/hindered settling: the role of water and its effect on latent heat release. Am. Mineral. 100 (8-9), 1762-1777. https://doi.org/10. 2138/am-2015-5121.

Lesta, P., Ferello, R., 1972. Región extra-andina del Chubut y norte de Santa Cruz. In: Leanza, A. (Ed.), Geología Regional Argentina. Academia Nacional de Ciencias, Córdoba, pp. 601-654.

Linares, E., González, R.R., 1990. Catálogo de edades radimétricas de la República Argentina 1957-1987. Publicaciones Especiales Serie B, Didáctica y Complementaria, vol. 19 Asociación Geológica Argentina, Buenos Aires.

Lizuaín, A., 1999. Estratigrafía y evolución geológica del Jurásico y Cretácico de la Cordillera Patagónica septentrional. In: Caminos, R. (Ed.), Geología Argentina. vol. 29. Subsecretaría de Minería de la Nación, Servicio Geológico Minero Argentino, Instituto de Geología y Recursos Minerales, Anales, Buenos Aires, pp. 433-556.

Lizuaín, A., 1980. Las Formaciones Suprapelozoicas y Jurásicas de la Cordillera Patagónica, provincias de Río Negro y Chubut. Rev. Asoc. Geol. Argent. 25 (2), 174-182.

Lizuaín, A., 1983. Geología de la Cordillera Patagónica entre las localidades de Lago Puelo y Leleque. P. Tesis doctoral. Universidad de Buenos Aires.

Lizuaín, A., Silva Nieto, D.G., 2005. Observaciones geológicas en la región de Río Chico, Gastre, río Chubut medio, provincia del Chubut, vol. 16. Congreso Geológico Argentino, La Plata, pp. 133-139 2005.

Llambías, E.J., Leanza, H.A., Carbone, O., 2007. Evolución tectono-magmática durante el Pérmico al Jurásico temprano en la Cordillera del Viento $\left(37^{\circ} 05^{\prime} \mathrm{S}-37^{\circ} 15^{\prime} \mathrm{S}\right)$ : nuevas evidencias geológicas y geoquímicas del inicio de la Cuenca Neuquina. Rev. Asoc. Geol. Argent. 62 (2), 217-235.

López de Luchi, M.G., Rapalini, A.E., 1997. Jurassic dyke swarms in the Sierra de Mamil Choique, North Patagonian massif: lithology, age and paleomagnetism. Simposio final IGCP Project 345. Lithospheric evolution of the Andes. Actas 8th Congreso Geologico Chileno 3, 31674-31679.

López De Luchi, M.G., Rapalini, A.E., 2002. Middle jurassic dyke swarms in the north Patagonian massif: the Lonco Trapial formation in the Sierra de Mamil Choique, Río Negro province, Argentina. J. S. Am. Earth Sci. 15 (6), 625-641. https://doi.org/10. 1016/S0895-9811(02)00083-4.

Lundstrom, C.C., Glazner, A.F., 2016. Silicic magmatism and the volcanic-plutonic connection. Elements 12 (2), 91-96. https://doi.org/10.2113/gselements.12.2.91.

Mahood, G.A., Halliday, A.N., 1988. Generation of high-silica rhyolite: a Nd, Sr, and O isotopic study of Sierra La Primavera, Mexican Neovolcanic belt. Contrib. Mineral. Petrol. 100 (2), 183-191. https://doi.org/10.1007/BF00373584.

Malvicini, L., Llambías, E., 1972. Geología y génesis del depósito de manganeso Arroyo Verde, provincia del Chubut. V Congreso Geológico Argentino, vol. 2. Villa Carlos Paz, Córdoba, Actas, pp. 185-202.

Maniar, P.D., Piccoli, P.M., 1989. Tectonic discriminations of granitoids. Geol. Soc. Am. Bull. 101, 635-643.
Márquez, M.J., Massaferro, G.I., Fernández, M.I., 2010. El volcanismo del complejo Marifil en Arroyo Verde, vertiente suroriental del Macizo de Somún Cura, Chubut. Revista de la Asociación Geológica Argentina 66 (3), 314-324.

Márquez, M.J., Massaferro, G.I., Fernández, M.I., Menegatti, N., Navarrete, C.R., 2011. El centro volcánico Sierra Grande: caracterización petrográfica y geoquímica del magmatismo extensional liásico, noreste de la Patagonia. Revista de La Asociación Geológica Argentina 68 (4), 555-570.

Márquez, M.J., Zubia, M.A., Giacosa, R.E., Trevisiol, S.A., Fernández, M.I., 2016. Características geológicas y metalogenéticas del Depósito Navidad (Ag-Pb-Zn-Cu) Macizo de Sumún Curá, Chubut, Argentina. SEGEMAR-Serie Contribuciones Técnicas Recursos Minerales 40, 150. https://doi.org/10.1590/S1516-18462008000300012.

Martínez Dopico, C.I., López de Luchi, M.G., Rapalini, A.E., Kleinhanns, I.C., 2011. Crustal segments in the North Patagonian Massif, Patagonia: an integrated perspective based on Sm-Nd isotope systematics. J. S. Am. Earth Sci. 31 (2-3), 324-341. https://doi.org/10.1016/j.jsames.2010.07.009.

Massaferro, G.I., 1999. Petrología de la secuencia Mesozoica del cerro Cuche, Chubut Occidental. Rev. Asoc. Geol. Argent. 54 (1), 60-73.

Mathieu, L., 2018. Quantifying hydrothermal alteration: a Review of methods. Geosciences 8 (7), 245. https://doi.org/10.3390/geosciences8070245.

McDonough, W.F., Sun, S.-s., 1995. The composition of the Earth. Chem. Geol. 120, 223-253. https://doi.org/10.1016/0009-2541(94)00140-4.

Molina, J.F., Scarrow, J.H., Montero, P.G., Bea, F., 2009. High-Ti amphibole as a petrogenetic indicator of magma chemistry: evidence for mildly alkalic-hybrid melts during evolution of Variscan basic-ultrabasic magmatism of Central Iberia. Contrib. Mineral. Petrol. 158, 69-98. https://doi.org/10.1007/s00410-008-0371-4.

Mpodozis, C., Ramos, V.A., 1989. The Andes of Chile and Argentina. In: In: Ericksen, G.E., Cañas Pinochet, M.T., Reinemund, J.A. (Eds.), Geology of the Andes and its Relation to Hydrocarbon and Mineral Resources, Circum-Pac, vol. 11. pp. 59-90 (Houston, Texas).

Mpodozis, C., Ramos, V.A., 2008. Tectónica Jurásica en Argentina y Chile: Extensión, subducción oblicua, rifting, deriva y colisiones? Rev. Asoc. Geol. Argent. 63 (4), 481-497.

Navarrete, C., Gianni, G., Encinas, A., Márquez, M., Kamerbeek, Y., Valle, M., Folguera, A., 2019. Triassic to Middle Jurassic geodynamic evolution of southwestern Gondwana: from a large flat-slab to mantle plume suction in a rollback subduction setting. Earth Sci. Rev. 194, 125-159. https://doi.org/10.1016/j.earscirev.2019.05. 002.

Niemeyer, H., Skarmeta, J., 1984. Hojas Península de Taitao y Puerto Aisén: Región de Aisén del General Carlos Ibañez del Campo: Carta Geológica de Chile 1: 500.000. Servicio Nacional de Geología y Minería, Santiago.

Nullo, J.F., 1978. Descripción Geológica de la Hoja 41d, Lipetrén, Provincia de Rio Negro. Boletín $\mathrm{N}^{\circ}$, vol. 158 Buenos Aires.

Nullo, F., Proserpio, C., 1975. La Formación Taquetrén en Cañadón del Zaino (Chubut) y sus relaciones estratigráficas en el ámbito de la Patagonia de acuerdo a la flora, República Argentina. Rev. Asoc. Geol. Argent. 30 (2), 133-150.

Oriolo, S., Schulz, B., González, P.D., Bechis, F., Olaizola, E., Krause, J., Renda, E., Vizán, H., 2019. The late paleozoic tectonometamorphic evolution of Patagonia revisited: insights from the pressure-temperature-deformation-time (P-T-D-t) path of the Gondwanide basement of the north Patagonian Cordillera (Argentina). Tectonics 38, 2378-2400. https://doi.org/10.1029/2018TC005358.

Page, R., Page, S., 1993. Petrología y significado tectónico del Jurásico volcánico del Chubut central. Rev. Asoc. Geol. Argent. 48 (1), 41-58.

Pankhurst, R.J., Caminos, R., Rapela, C.W., 1993. Problemas geocronológicos de los granitoides gondwánicos de Nahuel Niyeu, Macizo Norpatagónico. XII Congreso Geológico Argentino y II Congreso de Exploración de Hidrocarburos. pp. 99-104 (Mendoza).

Pankhurst, R.J., Leat, P.T., Sruoga, P., Rapela, C.W., Márquez, M.J., Storey, B.C., Riley, T.R., 1998. The Chon Aike province of Patagonia and related rocks in West Antarctica: a silicic large igneous province. J. Volcanol. Geoth. Res. 81, 113-116.

Pankhurst, R.J., Rapela, C.R., 1995. Production of Jurassic rhyolite by anatexis of the lower crust of Patagonia. Earth Planet Sci. Lett. 134, 23-36.

Pankhurst, R.J., Rapela, C.W., Fanning, C.M., Márquez, M., 2006. Gondwanide continental collision and the origin of Patagonia. Earth Sci. Rev. 76, 235-257. https:// doi.org/10.1016/j.earscirev.2006.02.001.

Pankhurst, R.J., Riley, T.R., Fanning, C.M., Kelley, S.P., 2000. Episodic silicic volcanism in Patagonia and the Antarctic Peninsula: Chronology of magmatism associated with the break-up of Gondwana. J. Petrol. 41 (5), 605-625. https://doi.org/10.1093/ petrology/41.5.605.

Pankhurst, R.J., Weaver, S.D., Hervé, F., Larrondo, P., 1999. Mesozoic - Cenozoic evolution of the north Patagonian batholith in Aysén, southern Chile. J. Geol. Soc. 156, 673-694.

Pavón Pivetta, C., Gregori, D., Benedini, L., Garrido, M., Strazzere, L., Geraldes, M., Costa Dos Anderson, S., Marcos, P., 2019. Contrasting tectonic settings in northern Chon Aike igneous province of Patagonia: subduction and mantle plume-related volcanism in the Marifil Formation. Int. Geol. Rev. 1-27. https://doi.org/10.1080/00206814. 2019.1669227. 00 (00).

Peccerillo, A., Taylor, S.R., 1976. Geochemistry of eocene calc-alkaline volcanic rocks from the Kastamonu area, Northern Turkey. Contrib. Mineral. Petrol. 58, 63-81.

Pedraza de Marchi, A., Ghidella, M., Tocho, C., 2017. Anomalía de subplacado magmático en el perfil $43.5^{\circ} \mathrm{S}$ del margen continental argentino. In: XXVIII Reunión Científica de la Asociación Argentina de Geofísicos y Geodestas, pp. 146-152.

Petersen, C., 1946. Estudios geológicos en la región del Río Chubut Medio. Dirección General de Minas y Geología, Boletín Nº, vol. 59. pp. 137p (Buenos Aires).

Profeta, L., Ducea, M.N., Chapman, J.B., Paterson, S.R., Gonzales, S.M.H., Kirsch, M., Petrescu, L., DeCelles, P.G., 2015. Quantifying crustal thickness over time in mag matic arcs. Nature 5, 1-7. https://doi.org/10.1038/srep17786. 
Proserpio, C.A., 1978. Descripción Geológica de la Hoja 42d, Gastre, Provincia del Chubut (1:200000). Boletín $\mathrm{N}^{\circ}$ 159, Buenos Aires.

Rapela, C., Pankhurst, R.J., 1993. El vulcanismo riolítico del Noreste de la Patagonia: un evento Meso-Jurásico de corta duración y origen profundo. In: 12o Congreso Geológico Argentino, Actas, vol. 4. pp. 179-188. https://doi.org/10.1590/S151618462008000300012. Mendoza.

Rapela, C.W., Kay, S.M., 1988. Late paleozoic to recent magmatic evolution of northern Patagonia. Episodes 11 (3), 175-182.

Rapela, C.W., Pankhurst, R.J., Harrison, S.M., 1992. Triassic "Gondwana" granites of the Gastre district, North Patagonian massif. Trans. R. Soc. Edinb. Earth Sci. 83, 291-304.

Rapela, C.W., Pankhurst, R.J., Fanning, C.M., Hervé, F., 2005. Pacific subduction coeval with the Karoo mantle plume: the Early Jurassic Subcordilleran belt of northwestern Patagonia. Geological Society, London, Special Publications 246 (1), 217-239. https://doi.org/10.1144/GSL.SP.2005.246.01.07.

Renda, E.M., Alvarez, D., Prezzi, C., Oriolo, S., Vizán, H., 2019. Inherited basement structures and their influence in foreland evolution: a case study in Central Patagonia, Argentina. Tectonophysics 772, 228-232. https://doi.org/10.1016/j. tecto.2019.228232.

Riley, T.R., Leat, P.T., 1999. Large volume silicic volcanism along the proto-Pacific margin of Gondwana: lithological and stratigraphical investigations from the Antarctic Peninsula. Geol. Mag. 136 (1), 1-16. https://doi.org/10.1017/ S0016756899002265.

Riley, T.R., Leat, P.T., Pankhurst, R.J., Harris, C., 2001. Origins of large volume rhyolitic volcanism in the Antarctic Peninsula and Patagonia by crustal melting. J. Petrol. 42 (6), 1043-1065.

Riley, T.R., Flowerdew, M.J., Pankhurst, R.J., Curtis, M.L., Millar, I.L., Fanning, C.M., Whitehouse, M.J., 2016. Early jurassic magmatism on the Antarctic Peninsula and potential correlation with the Subcordilleran plutonic belt of Patagonia. J. Geol. Soc. 174, 365-376. https://doi.org/10.1144/jgs2016-053.

Rolando, A.P., Hartmann, L.A., Santos, J.O.S., Fernández, R.R., Etcheverry, R.O., 2002. SHRIMP zircon $\mathrm{U} \pm \mathrm{Pb}$ evidence for extended Mesozoic magmatism in the Patagonian Batholith and assimilation of Archean crustal components. J. S. Am. Earth Sci. 15, 267-283.

Rolleri, E.O., 1970. Discordancia en la base del Neopaleozoico al este de Esquel. Comunicación) Cuartas Jornadas Geológicas Argentinas, vol. 2. Actas, Buenos Aires, pp. 273-277.

Sacomani, L.E., Panza, J.L.A., Parisi, C., Pezzuchi, H., 2007. Hoja Geológica 4366-III, Las Plumas, provincia del Chubut, vol. 291 Boletín Nº Buenos Aires.

Sato, A.M., Basei, M.A.S., Tickyj, H., Llambías, E.J., Varela, R., 2004. Granodiorita El Sótano: Plutón jurásico deformado aflorante en el basamento de Las Grutas, Macizo Norpatagónico Atlántico. Rev. Asoc. Geol. Argent. 59 (4), 591-600.

Schiuma, M., Llambías, E.J., 2008. New ages and chemical analysis on lower jurassic volcanism close to the dorsal de Huincul, Neuquén. Rev. Asoc. Geol. Argent. 63 (4), 644-652.

Shand, S.J., 1943. Eruptive Rocks. Their Genesis, Composition, Classification, and Their Relation to Ore-Deposits with a Chapter on Meteorite. John Wiley \& Sons, New York.

Shellnutt, J.G., Bhat, G.M., Wang, K.L., Brookfield, M.E., Dostal, J., Jahn, B.M., 2012. Origin of the silicic volcanic rocks of the early permian Panjal Traps, Kashmir, India. Chem. Geol. 334, 154-170. https://doi.org/10.1016/j.chemgeo.2012.10.022.

Silva Nieto, D.G., 2004. Hoja geológica 4369-III, Paso de Indios. Escala 1:250.000. Instituto de Geología y Recursos Minerales, Servicio Geológico Minero argentino. Boletín $N^{\circ}$ 265, 72 (Buenos Aires).

Silva Nieto, D., Cabaleri, N., Salani, F., Márquez, M., González Díaz, E., Coluccia, A., 2002. Hoja Geológica 4369-27 Cerro Cóndor, Provincia del Chubut. Escala1:100.000. Instituto de Geología y Recursos Minerales, Servicio Geológico Minero Argentino. Boletín $N^{\circ} 328,68$ (Buenos Aires).

Sisson, T.W., Grove, T.L., 1993. Experimental investigations of the role of $\mathrm{H}_{2} \mathrm{O}$ in calcalkaline differentiation and subduction zone magmatism. Contrib. Mineral. Petrol. 113, 143-166. https://doi.org/10.1007/BF00283225.

Spalletti, L.A., Franzese, J.R., Morel, E., D'Elia, L., Zúñiga, A., Fanning, C.M., 2010. Consideraciones acerca de la sedimentología, paleobotánica y geocronología de la Formación Piedra del Águila (Jurásico Inferior, Neuquén, República Argentina). Rev. Asoc. Geol. Argent. 66, 305-313.

Spikermann, J.P., Strelin, J., Marshall, P., Carrillo, R., Montenegro, T., Lago, M., Villalba, E., Pérez, A., 1988. Geología del área del Batolíto Aleusco, Departamento de Languiñeo, provincia de Chubut. Revista de La Asociación Argentina de Mineralogía. Petrología y Sedimentología 19, 39-48.

Spikermann, J.P., Strelin, J., Marshall, P., Carrillo, R., Montenegro, T., Lago, M., Villalba, E., Pérez, A., 1989. Caracterización geológica y petrológica del Batolito Aleusco, Departamento Languiñeo, Provincia de Chubut. Revista de La Asociación Argentina de Mineralogía. Petrología y Sedimentología 20, 33-42.

Storey, B.C., Leat, P.T., Ferris, J.K., 2001. The location of mantle-plume centers during the initial stages of Gondwana breakup. In: Ernst, R.E., Buchan, K.L. (Eds.), Mantle Plumes: Their Identification through Time. Geological Society of America. https:// doi.org/10.1130/0-8137-2352-3.71.

Strazzere, L., Gregori, D.A., Benedini, L., Marcos, P., Barros, M., 2017. Edad y petrografía del Complejo Volcánico Marifil en la Sierra de Pailemán, Comarca Nordpatagónica, Río Negro, Argentina. XX Congreso Geológico Argentino, pp. 145-150 (San Miguel de Tucumán).

Strazzere, L., Gregori, D.A., Benedini, L., Marcos, P., Barros, M.V., Geraldes, M.C., Pavon, C., 2019. Geoscience Frontiers the Puesto Piris formation: evidence of basin-development in the north Patagonian massif during crustal extension associated with Gondwana breakup. Geoscience Frontiers 10 (1), 299-314. https://doi.org/10.1016/ j.gsf.2017.12.019.

Suárez, M., De la Cruz, R., Aguirre-Urreta, B., Fanning, M., 2009. Relationship between volcanism and marine sedimentation in northern Austral (Aisén) Basin, central Patagonia: stratigraphic, U-Pb SHRIMP and paleontologic evidence. J. S. Am. Earth Sci. 27, 309-325.

Suárez, M., Emparan, C., 1995. The stratigraphy, geochronology and paleophysiography of a Miocene fresh-water interarc basin, southern Chile. J. S. Am. Earth Sci. 8, 17-31.

Suárez, M., Márquez, M., 2007. A Toarcian retro-arc basin of Central Patagonia (Chubut), Argentina: middle Jurassic closure, arc migration and tectonic setting. Rev. Geol. Chile 34 (1). https://doi.org/10.4067/S0716-02082007000100004.

Suero, T., 1948. Descubrimiento del Paleozoico superior en la zona extraandina de Chubut. Bol. Inf. Pet. (1924) 25 (287), 31-48.

Sun, S.S., McDonough, W.F., 1989. Chemical and isotopic systematics of oceanic basalts: Implication and processes. In: In: Saunders, A.D., Norry, M.J. (Eds.), Magmatism in the Ocean Basins, vol. 42. Geological Society Special Publication, pp. 313-345.

Taylor, S.R., McLennan, S., 1995. The geochemical evolution of the continental crust. Rev. Geophys. 33, 241-265.

Turner, J.C., 1983. Descripción geológica de la Hoja 44d, Colan Conhué, Provincia del Chubut, Boletín $\mathrm{N}^{\circ}$ 197. (Buenos Aires).

Uliana, M.A., Biddle, K.T., 1987. Permian to Late Cenozoic evolution of northern Patagonia: main tectonic events, magmatic activity, and depositional trends. In: MCkenzie, G.D. (Ed.), Gondwana Six: Structure, Tectonics and Geophysics. Geophysica. American Geophysical Union, pp. 271-286.

Varela, R., Basei, M.A.S., Cingolani, C.A., Siga, J.O., Passarelli, C.R., 2005. El basamento cristalino de los Andes norpatagónicos en Argentina: geocronología e interpretación tectónica. Andean Geol. 32 (2), 167-187.

Vizán, H., Prezzi, C.B., Geuna, S.E., Japas, M.S., Renda, E.M., Franzese, J., Van Zele, M.A., 2017. Paleotethys slab pull, self-lubricated weak lithospheric zones, poloidal and toroidal plate motions, and Gondwana tectonics. Geosphere 13 (5), 1541-1554. https://doi.org/10.1130/GES01444.1.

Volkheimer, W., Lage, J., 1981. Descripción geológica de la Hoja 42c, cerro Mirador, provincia de Chubut. 181. Secretaría de Estado de Minería, Ministerio de Economía, pp. 1-71 Scale: 1: 200000Boletin.

Wilson, M., 2007. In: Igneous Petrogenesis: a Global Tectonic Approach. Kluwer Academic Publishers, Dordrecht, The Netherlands Springer.

Winchester, J.A., Floyd, P.A., 1977. Geochemical discrimination of different magma series and their differentiation products using inmobile elements. Chem. Geol. 20, 325-343. https://doi.org/10.1016/0009-2541(77)90057-2.

Whittington, A.G., Hofmeister, A.M., Nabelek, P.I., 2009. Temperature-dependent thermal diffusivity of the Earth's crust and implications for magmatism. Nature 458 (7236), 319-321. https://doi.org/10.1038/nature07818.

Zaffarana, C.B., Somoza, R., López de Luchi, M., 2014. The late Triassic central Patagonian batholith: magma hybridization, ${ }^{40} \mathrm{Ar} /{ }^{39} \mathrm{Ar}$ ages and thermobarometry. Journal of South America Earth Sciences 55, 94-122. https://doi.org/10.1016/j. jsames.2014.06.006.

Zaffarana, C., Gallastegui, G., Lagorio, S., Poma, S., Busteros, A., Serra Varela, S., Orts, D., Silva Nieto, D., Giacosa, R., Ruiz González, V., Puigdomenech, C., Boltshauser, B., Somoza, R., 2018. Geochemical signature and reservoir conditions of early jurassic calc- alkaline volcanic rocks from Lonco Trapial formation, central Patagonia. J. S. Am. Earth Sci. 88, 415-445. https://doi.org/10.1016/j.jsames.2018.09.006.

Zaffarana, C.B., Somoza, R., 2012. Palaeomagnetism and ${ }^{40} \mathrm{Ar} /{ }^{39} \mathrm{Ar}$ dating from Lower Jurassic rocks in Gastre, central Patagonia: further data to explore tectonomagmatic events associated with the break-up of Gondwana. Journal of the Geological Society of London 169, 371-379. https://doi.org/10.1144/0016-76492011-089. Palaeomagnetism.

Zappettini, E.O., Dalponte, M., Leanza, H.A., Lagorio, S., 2011. Edad y correlación de la Formación Colomichicó, sector septentrional de la Cordillera del Viento, Neuquén, Argentina. In: 18 Congreso Geológico Argentino, pp. 2-3 (Neuquén).

Zappettini, E.O., Lagorio, S.L., Dalponte, M., Orestes, J., Belousova, E., 2018. Evidencias de magmatismo precuyano (Pliensbachiano - Toarciano) en el norte de la Cordillera del Viento, provincia del Neuquén: caracterización geoquímica, isotópica e implicancias tectónicas. Rev. Asoc. Geol. Argent. 75 (4), 533-558.

Zartman, R.E., Doe, B.R., 1981. Plumbotectonics-The model. Tectonophysics 75 (1-2), 135-162. 